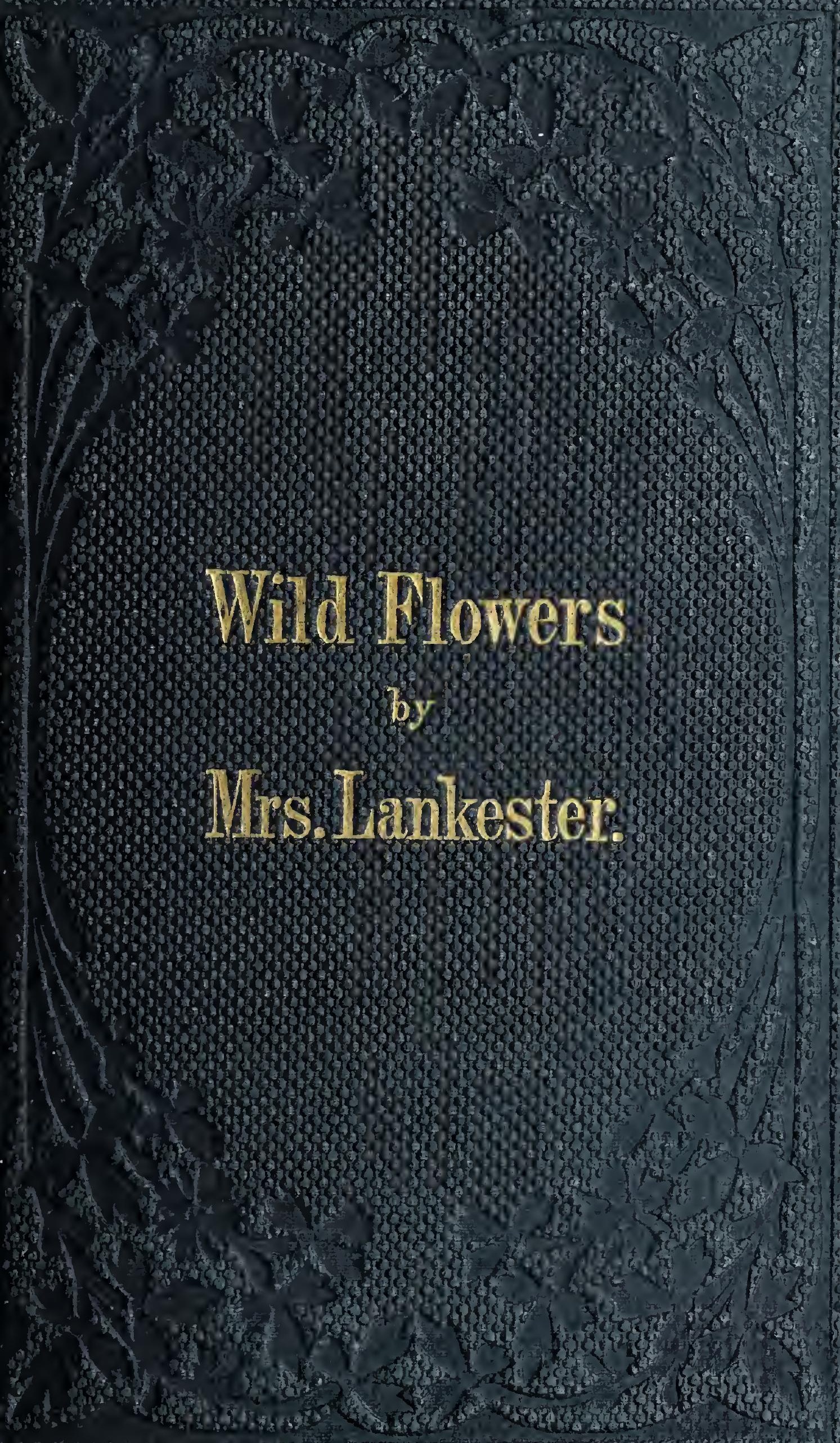




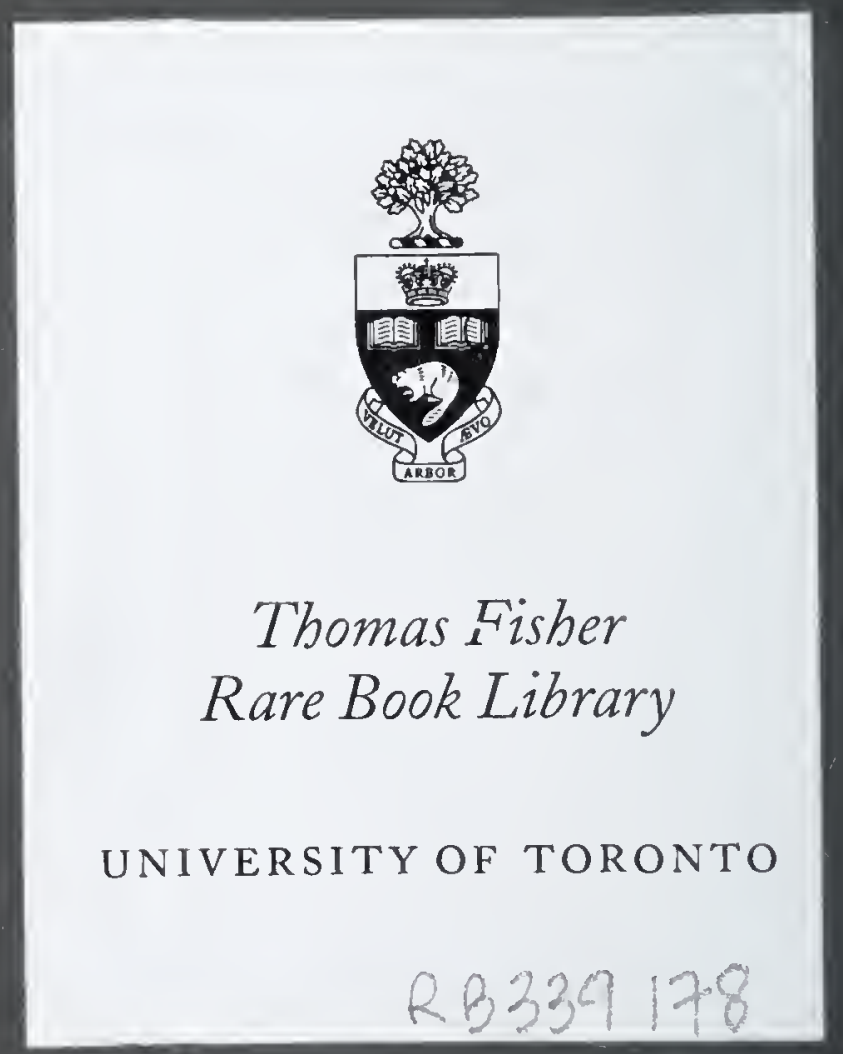



Digitized by the Internet Archive in 2019 with funding from University of Toronto

https://archive.org/details/wildflowersworth00lank 



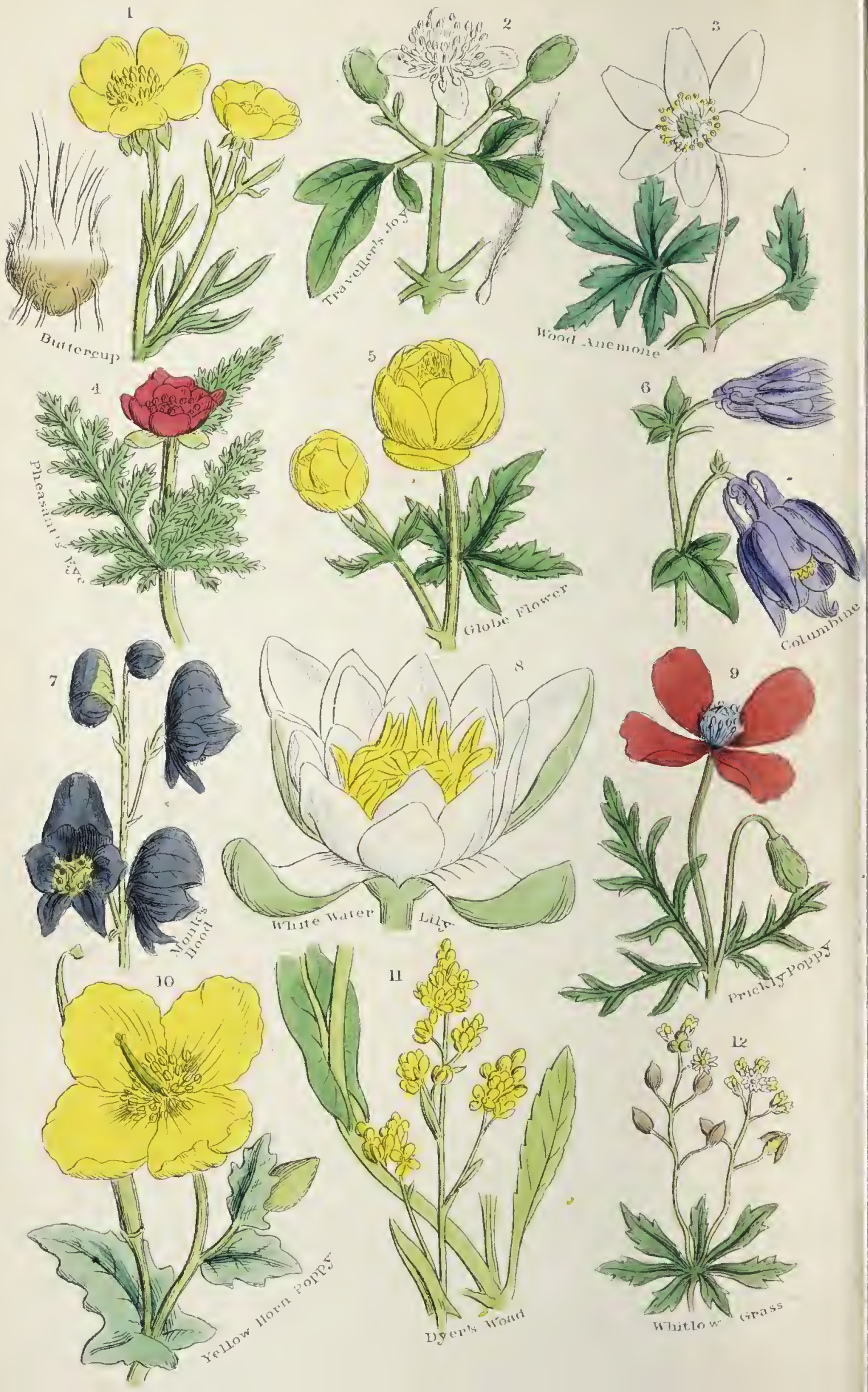




\section{WILI) FLOWERS WORTH NOTICE.}

EITล

SELECTION FROM THE BRITISH FLOHA

()F SOME OF OUR NATIVE PIAN'IS,

WIICII $\triangle \mathrm{KE}$

HOST ATTRACTIVE

FRORX

THEIR BEAUTY, USES, OR ASSOCIATIONS.

i. $Y$

NIS. L A N K E T ER,

ACTHOB OF "A PLAIN AND IASY ACCOUNT OF BHITISI FEHSS"

FULLY ILLUSTRATED

LY J. E. SOWLRBY.

LONDON :

ROBERT HARDWICKE, 192, PICCADILLY. 



\section{PREFACE}

M $\mathrm{x}$ little book on Ferns has been so kindly and well received, that I bave been encouraged to supplement it with these pages on "Wild Flowers worth Notice." It has been a difficult task to make a selection, - for what flowers are not worth notice? As, however, this cannot pretend to be an exhaustive treatise on the British Flora, such as exists in many forms and in large ponderous volumes compiled by profound and learned botanists, I have endeavoured to choose such plants as are representatives of particular families, and are remarkable either for their beauty of appearance or useful properties, and to give the best botanical description I can either find or make of them, so as to insure their recognition with the aid of the plate, and to aud sucl traditions, legends, and poetical fancies, as ale associated with them, in order to increase the interest with which they may be regarded.

I lately heard a very eloquent and popular preacher discourse of wild flowers and the "lilies of the field," in a strain so completely in harmony with my own thoughts while I harl been busy during the week in writing of all their charming and modest beauty, that I felt he too must be a lover of wild flower's and have himself rejoiced in these blessed gifts of beauty which gladden the earth, and remove from man one of the great evils of his fall. Surely, said the preacher, we may regard all that is lovely in nature, the trees, grass, blue sky, sunshine, nud above all, wild flowers, as secondary blessings, which we receive and enjoy by virtue of the covenant made with Adam. No thanks to the busbandnian that they spring up on every side, gladdening our hearts and cheering our lives; there they are each in its season, without care, without tending. The Great Architect of this glorious world depends not on his creatures for the preservation of these adormments of his universe, but has implanted within each tiny cup or bell that which shall perpetuate itself, and from age to age shall gladden the heart of the pnorest wayfarer. "Consider the lilies of the field, how they grow; they toil not, neither do they spin: aud yet $I$ 
say unto you that even Solomon in all his glory was not arrayed like one of these."

Longfellow well says-

"Wond'rous truths, and manifold as wond'rous, God hath written in the stars above;

But not less in the bright flow'rets under us Stands the revelation of His love."

Then the natural connection between wild flowers and bright sunshine, or the first warm days of spring, does it not recall many a pleasant ramble to those who are in the enjoyment of youth and health? And even to the feeble or afflicted, the remembrance of the soft lulling influence of a summer's day, in sweet rural scenes, when everything seems joyous and yet tranquil, is a refreshment and a delight. In a charming series of short essays, called "The Recreations of a Country Parson," is one "Concerning Summer Days," which is so full of pleasant thoughts and the love of green trees and fields, hedges and hedge-rows, that I cannot but wish he would also write "Con. cerning Wild Flowers." When I first began to write of "Wild Flowers," it was suggested to ine that I should select only those susceptible of cultivation; but to me, the great charm of the whole subject is to fancy the beautiful creatures in their natural homes, where they love to grow, not where they are artificially placed and tended by the hand of man. The wild bryony and clematis climbing luxuriantly over ledge and neighbouring tree-none the less rich for the demands made upon it by groups of happy smiling children for wreaths and festoons of wonderful length. The blue forget-me-not peeping out from its bed of green leaves by the side of the clear rumning stream, asking only for moisture to fringe its sides with turquoise flowers. A hundred other lovely "children of the earth," as the blind girl of Bulwer calls them, owe much of their charm to the "lap" from which they spring-fresh and untouched by the hand of man. Not that I would in any manner depreciate the gardener's art or the skill of the florist, in so tending and cultivating even our native plants, as to produce such perfection of colour and symmetry of form, that it is difficult to recognize our friends of the wayside in the beauties of the garden. But this is surely the adniration with which we regard the welldressed and fashionable denizens of a city in contrast with the more simple, but, perhaps, not less refined l'ustic beauties. Then these favounites of ours must be sought for, - they call forth the energy and self-denial of their admirers, and while making great demands in the shape of country walks, and mountain rambles, bestow on their captors rosy clieeks, the inestimable prize of healthful and vigorous frames. 
I bave often, when urging the necessity of long walks and frequent exercise, been told by young folks living in the inidst of rustic lanes, "There is no object to go out for. In cities and towns there are a hundred objects, and we are thus beguiled into walking." Why not then secure an object, if but one, for a country walk; an object which wili unfailingly repay you and be cheering in the remembrauce? Cultivate an acquaintance with the wild flowers of your own district, study them, gather them, transplant them if you will into a corner of your own garden; but, above all, visit them in theil own homes, and be not satisfied till you have made a tolerable friendship with most of our British plants. Like all things of beauty, they perish quickly; and though each month of the year brings its own attractions with it, from the snowdrop of the early spring to the misletoe and lichen of dark December, the lover of flowers will like to preserve the forms of as many fivourites as possible, by drying; and few who liave botanized in youth, cannot moralize in maturer age over the remembrances thus furnished, and few who have once engaged in collecting plants ever lose the recollection of the study or the interest it inspired. I therefore say to all, observe, collect, and preserve, the wild flowers you find; arrange and name them scientifically, if possible; but if that be not in your power, still they will always be interesting to you as a pleasing record of "times and places, and old fimiliar faces," which one day you will value. When you have become well acquainted with the wild plants of your own neighbourhood, there are always rare ones to look for, and great is the interest and excitement attending the discovery of a xare species in an unexpected locality; but before you can expect to become a discoverer, you inust be a tolerable botanist. But botany, like other sciences, requires earnest and systematic study. Those who wish to be able to discover the name of a plant by the aid of botanical books, must first thoroughly understand the structure of a plant. Such a knowledge nnay be gained by the study of the late Professor Henfrey's "Rudiments of Botiny," or Dr. Dresser's "Popular Manual of Botany." When the structure has been mastered, then the descriptions in such volumes as Babiugton's "Manual of Botany," and Bentham's "British Nlora ;" or the larger works of Sunith, Withering, and Sowerby, may be used with success.

Let it not be supposed, however, that this search after wild flowers need be confined to such as have at their disposal all the appliances of science. The poorest iuhabitant of a cottage has within her reach the same delight from this pursuit as the lady of the mansion, and we have many instances of the successful cultivation of botany by those who have to labour hard for their daily bread. Among the hills which surround the great 
manufacturincr city of the North, Manchester, and even within the very atmosphere of its smoke, there exists, at this day, a club of working naturalists-chiefly botanists. All of them are artisans in some one of the great factories of the district. An account published by one of themselves of their weekly botanical excursions, their field-days, and the healthful and exhilarating effect on the minds and bodies of the members of this club, is most encouraging and delightful. The actual longevity of these humble naturalists is very remarkable. Old Crowther, one of the earliest workers in this direction, died at the age of 79 ; he was a simple-hearted man, willing to travel any distance and undergo any fatigue, so that he secured his flower. As one of his old companions said, "he was not learned, but he was very loving." Henever touched his wages for the purpose of botanical pleasure, but took home every penny, and irusted to fortunate accidents for the menns of supplying his scientific wants. An account of the life and labours of another of this noble fraternity, the late Samuel Gibson, of Hebden Bridge, appeared in the Manchester Gucerdian, of the 30th May, 1849. His herbarium of plants was sold after his death for the sum of $£ 75$, and many portions of his collection are now to be seen in the Pcel Park Museum, Salford. In 1858, an annual ineeting of these working men naturalists took place near Manchester, at which there mustered not less than 200 zealous and well-informed botanists, all, with the exception of four or five, of the artisan class. The one striking feature of this meeting seems to have been the hale and hearty appearance of the men already advanced in life; they were fine specimens of youth carried on into old age. There is evidently something in natural history wonderfully promotive of length of days. Men never step into the presence of nature with affection and reverence, but they come back blessed and strengthened with a reward.

We have a noble example of what may be done in this direction, even at an early age, in the labours of the late Rev. Professor Henslow, of Hitcham, in Suffolk. The interest he took in his parish schools induced him to think that the girls might with advantage know something of the plants and vegetation of their own village. With his characteristic energy and goodness, he set about teaching all who chose to learn, the elements of botany, and by the encouragement of his own kindly smile and approving words, he soon succeeded in establishing a genuine love for plants, not only to look at, but to understand, in the minds of these children. The good professor arranged for his pupils a system of naming, classifying, and drying their specimens, and but few girls in the village of Hitcham are now unacquainted with their native plants. A good collection, made, dried, and named by these young botanists, may be inspected any day in the educational 
department of the South Kensington Museum, where it is depusited as an example and an encouragement to other village schools. It is but right to add that the testimony of the Inspectors of Schools goes to prove that this scloool ranks far above the average of schools in the district in every respect; and that in no way is there any difference in its rules or arrangements, with the exception of the introduction of botany. We can, perhaps, readily accolnt for the indirect influence of this study on the habits and minds of the pupils. The attention it awakens, the methods of arrangement and order it encourages, and the accuracy it necessitates, must re-act, in a great measure, on the whole character and thoughts of the learner.

I am glad here to refer to the encouragement lately giren to scientific instruction in schools by the Committee of Council on Elucation; and it would be well that not only our national and village school-teachers should avail themselves of the advantages thus offered, but that our middle and higher-class schools should follow the example. At present the movement is in its infancy, and the full bearing and tendency of offering certificates and prizes to authorized teachers is scarcely understood; but, from the working of the matter since its first introduction, we may fairly predict that unless our sons and daughters awake to a sense of the necessity for exertion and study in this direction, they will be left far behind in the knowledge of the world they live in by the boys and girls of village schools. A series of lectures has been published by the Examiners in Science in the Department of Education, "addressed to teachers on preparation for obtaining science certificates, and the method of teaching a science class." To the one on Botany, price $2 d$., I would specially refer as explaining and amplifying much that I should wish to say liere on the nature and advantages of this study. A Directory, price $6 d$., is also published, containing minute particulars as to regulations for establishing and conducting science classes in schools. Either of these pamphlets may be obtained by application to the Secretary of the Science and Art Department, South Kensington Museum. The late Rev. Professor Henslow, ever anxions to assist aud gratify others at any personal sacrifice, sent me, in spite of the severe and painful illness which carried lim off, a little pamphlet prepared as a companion to the specimens of his school plants deposited in the Kensington Museum, entitled "Illustrations to be employed in Practical Lessons ou Botany." In it he gives full particulars of the system be has pursued in his schools at Hitcham, and every direction for the commencement of the study of Botany, with little wood-cuts as unmistakable guides. Nearly every book on botany contains directions as to drying plants, and in my "Plain and Easy Account of Dritish Ferus," I have endeavoured to be as clear as 
possible on this point. Here, therefore, I would only say to those who wish to make a collection of dried plants, get Bentall's drying-paper, and two boards strapped together with two strong leather straps sufficient to produce considerable pressure. Change your paper often while your plants are drying; when dry, put them down carefully with bits of gummed paper on foolscap sheets; write the name, order, locality and date of tinding, neatly underneath. It is a good plan to have a sheet of thick cartridge or brown paper for each family, to enclose all the specimens belonging to that family. You can then place these cases on shelves, in drawers, or a portfolio, for safety and preservation.

Before closing these remarks I would refer to Mr. J. E. Sowerby's "British Wild Flowers," as the only volume with which I am acquainted, containing in a small compass draw. ings of every known British plant, so carefully executed as to require little or no explanation for the purpose of identifying any special plant by its aid. It seemed to me, however, that it would neither be inappropriate nor unprofitable to show in a selected number of specimens the sort of interest which attaches to every one of these plants, and in what way and with how much enjoyment their acquaintance may be cultivated and improved.

"God made the flowers to beautify

The earth, and cheer man's careful mood;

And he is happiest who has power

To gather wisdom from a flower,

And wake his heart in every hour

To pleasant gratitude."

WORDSWORTE。 


\section{INTRODUCTION.}

Tuis little volume certainly does not presume to be a work on Botany, strictly so called, of which there are so many and such exhaustive guide-books to the British Flora. It is not my intention to describe each Natural Order or Family to which our specimens belong. Nearly every reader who is sufficiently interested in plants to care to look for them, and to compare them with the plates and descriptions here given, will already know what constitutes a family, or natural order; but lest some one should take up this book who has not given any previous attention to the subject, I would say that the whole vegetable kingdom is divided into three great classes. These, again, are subdivided into orders, families, or tribes, according as they most resemble each other; these are again subdivided into genera, and again into species. We may popularly explain the system of classifying, thus:-In a library there shall be a number of volumes of all sizes, shapes, and containing varieties of matter ; we agree to classify them not only by size and colour, but according to their contents. Take all those treating of chemistry, then all those on botany; let those be families or orders; then all the red-bound chemical books,-that is a genus; then from those separate the volumes with gilt leaves of a certain size, and those with marbled leaves, of a certain size,- these constitute species. In this way have our great botanists divided the vegetable kingdom for the convenience of arrangement and study; and although there are often differences of 
opinion as to what shall constitute a species or a variety, which would correspond in a library to a red, giltedged book, with a slight change of style in the cover, say with a thicker, stouter back than the rest; yet in the main there is but little difficulty in preserving order and in classifying every known plant according to its peculiarities. It is very necessary for any one who wishes to study Botany to understand thoroughly the distinguishing points of each natural order. When once these are fixed in the mind, it is easy to recognize plants as belonging to certain families, and from the established habits of the family to draw conclusions as to the nature, locality, and properties of the specimen under notice. In order to give some notion of the nature of a Natural Order or Family, I think it well to give a sketch of that to which our first specimen belongs, and which comes first in nearly all works on Butany.

Ranunculaces. - The plants belonging to this order are herbs or climbing plants, never shrubs or trees. The flowers are solitary, that is, singly, on a stalk, or in racemes, that is, in bunches of irregular flowrets. The petals are generally five, but sometimes are deformed and very minute, or wanting altogether. The stamens are very numerous, and placed on the receptacle. The fruit is composed of several carpels, distinct or partially united. The seeds are erect or pendulous. The family Ranunculacece are widely diffused all over the globe, but especially in cool and temperate climates. Within the tropics they are chiefly confined to high mountain districts. They are remarkable for their acrid, poisonous qualities in many of the species of Ranunculus; the acrid secretion in the leaves will produce blisters if applied to the skin; whilst the Aconite or Monk's Hood is a deadly poison. A good example of the chief characteristics of the family is afforded by the species figured in our Plate No. 1. 


\title{
WILD FLOWERS.
}

\section{BUTTERCUP, OR BULBOUS CROWFOOT.}

\author{
(Fig. 1.)
}

\section{RANUNCULUS BULBOSUS.}

The name Buttercup is fumiliarly applied to nearly all the species of Ranunculus with bright yellow flower's. This species is distinguished from the rest by its thickened stem, which at the lower part, under the ground, expands into a sort of bulb, and by the sepals, which, as soon as the flower expands, are reflexcd or turned back on the peduncle. The leaves are divided into three stalked segments, more or loss cut. The whole plant is about a foot high; it flowers in the early summer, and is abundant in our meadows and waste places. In Scotland it is found southwards; but in the north is seldlom to be seen. The genus Ranunculus is the type of the natural order Ranunculaces. The species are generally acrid, and not eatcn by cattle in their growing state. 


\section{TRAVELLERS' JOY-OLD MAN'S BEARD,}

\section{OR VIRGIN'S BOWER.}

(Fig. 2.)

\section{CLEMATIS VITALBA.}

Clematis Vitalba belongs to an almost exceptional genus of the Ranunculus fimily. Its stem is climbing, and woody at the base; it is the only British plant which gives us some faint notion of the bush ropes of the tropics. The woody stems sometimes attain a great thickness, and the petioles or leaf-stalks of the young branches act as tendrils, and cause it to spread to a great extent over trees and shrubs in its neighbourhood. The flowers are of a greenish-white colour, in loose bunches. The carpels are very conspicuous when ripe, from their persistent styles, which grow into long feathery awns; hence the name, Old Man's Beard. The petals are absent in this species, the flowers being formed by the sepals. The leaves are pinnate; the leaflets, usually five in number, ovate and slightly pointed in shape. This pretty and slightly sweetscented plant is one of the greatest ornaments of our country hedges; and we can, cloubtless, all remember with pleasure the delight with which in our summer rambles we have torn down long wreaths of its pretty green leaves and pale flowers to adorn a rustic headdress, or to luxuriate in its fragrance, which it possesses in some degree in common with its relation C. Flammula, the deliciously fragrant plant so well known in our gardens. 
There are above a hundred species of Clematis, most of which are favourite plants in cultivation. Both our own British species, Clematis Vitalba and C. crispa (an exotic species), have been used as rubefacients in rheumatism, and the dried leaves of $C$. Vitalbu form fodder for cattle in some places, the acrid juice they contain when green disappearing after drying. When dried, boys use clematis wood for smoking as they do ratan. A thin slice of the wood is an interesting object under the microscope, from the curions manner in which the parts of the stem are arrauged.

\title{
TrOOD ANEMIONE, OR WIND-FLOWER.
}

\author{
(Fig. 3.)
}

\section{ANEMONE NEMOROSA.}

THis is one of our commonest and prettiest hedgeplants, belonging to the same order, Ranunculacer. The whole of the anemones are lowly herbs, usually perennial, as is this species. The flowers are solitary, consisting of six smooth white elliptical sepals. The leaves consist of three ovate or lanceolate leaflets, of a dark bright-green colour. The flowers may be seen in or near woods as soon in the year as April, and our earliest spring walks are often gladdened by its presence. Nothing can be prettier than a bouquet of these simple delicate white flowers in the midst of their natural guardians, the dark finely-cut green 
leaves; they are among the earliest harluingers of the season,

When earth, exulting from her wintry tomb, Breaks forth with flowers.

'To see these delicate flowers in perfection, however, we must chonse for our woodland excursion a bright unclouded day, for the Wood Anemone is a natural barometer, and droops at the approach of rain. There are several British species of anemone; but we have selected the $A$. nemorosa as the most attractive from its very simplicity.

Anemone Pulsatilla, has fine large purple flowers. A. Pceonia, the Peacock Anemone, common in the south of Europe, with its bright scarlet or scarlet and white flowers; and A.coronaria, the garden Anemone, with its many varieties of hue, form striking contrasts to the unobtrusive appearance of our little farourite. The whole genus partake of the acrid and poisonous qualities of the family, and are unsafe to take, even as medicines, althongh they have had a reputation in various complaints.

\section{PHEASANT'S EYE.}

(Fig. 4.)

\section{ADONIS AUTUMNALIS.}

Adonis autumralis,-Pheasant's Eye,-rartakes more of the character of the true Ranunculus than 
any plant we have yet described; it is distinguished from that genus by the absence of a little scale at the base of the petals, and from other genera of the same order by the numerous hard, dry, sharp-pointed grains of which its fruit consists. It is an upright annual plant, from eight inches to a foot in height. The leaves are finely cut into numerous narrow linear segments. The sepals are green or slightly coloured; the petals from five to eight in number, but slightly longrer than the calyx, of a bright scarlet colour, with a dark or black spot at the base inside the flower. It is constantly to be found in cornfields in the summer, from May to September in England and Ireland, and sometimes in Scotland.

\section{GT.OBE FLOWER.}

(Fig. 5.)

\section{TROLLIUS EUROPEUS.}

Trollius Europeus, Globe Flower, belongs also to the order Ranunculacex, and is so called from the German word trollen, round, in reference to the round shape of the flowers. The species are all perennial herbs, with divided leaves and yellow flowers, composed of coloured sepals. It is not a large genus, and our native species, Trollius Europceus, is the most generally known. It has from ten to fifteen broad concave sepals, usually turned over in the shape of a ball, and concealing petals, stamens, and carpels. 
In Scotland it is called Lucken Gowan, or Cabbage Daisy. In some parts of England, as well as on the continent of Europe, they are gathered on festive occasions for making garlands and decorating the cottages of the peasantry. In common with its natural order, this plant is slightly acrid. It likes a rich, moist soil, but loves a good strong light to flourish under ; deriving vigour and colour as the moon derives her light.

\section{COLUMBINE。}

(Fig. 6.)

\section{AQUILEGIA VULGARIS.}

Aquilegia, literally water-gatherer, is another genus of plunts of the Ranunculus family, so called because the leaves collect water in their hollow. A. vulgaris, the Common Columbine of our hedges, is a pretty little plant with a stem from one to two feet high or more. The flowers, which are curious, are of a dull purple or blue colour, and drooping. The root-leaves and those at the lower part of the stem grow in a large tuft, each with a long stalk. The petals have all a long curved horn or spur at their base, which projects below the calyx. The stamens are numerous. The English name, Columbine, is derived from a fanciful likeness to a dove, which is produced if we separate one petal from the flower-cluster; it brings with it two sepals, and the appearance of a dove may be imagined. When wild, the blussom is of a light-blue colour, but 
the plant is subject to great changes in cultivation, and readily produces double flowers. We find in "Brown's British Pastorals," that our dove-like plant was, in former times, the insignia of a deserter lover :-

"The Columbine by lonely wand'rer taken, Is there ascribed to such as are forsaken."

\section{MONK'S-HOOI, OR WOLF'S-BANE.}

(Fig. 7.)

\section{ACONITUM NAPEILUS.}

Aconitum Napellus is a plant with a firm erect stem one and a half to two feet high, also belonging to the Ranunculaceæ. The leaves are either stalked or very close to the stem, of a dark-green colour and very smooth. The flowers are large, and are easily recognized as having the very large uppermost segment of the calyx overhanging the petals and other parts in the form of a helmet. The two upper petals inside this covering are long and narrow, with spurs; the three lower ones very small. We may all remember having plucked these flowers in our childhood and having thrown back the hood or calyx, have delighted in the fairy chariot and steeds formed by the petals thus set free. No vegetable poisons are more powerful than those produced by this genus of plants; and the common species, A. Napellus, yields it in the greatest degree. It is sometimes prescribed medicinally, and according to some writers very beneficially. 
From ancient times these plants have been celebrated as virulent poisons. In 1524 and 1526 two criminals at Rome and at Prague, to whom the root was given by way of experiment, very quickly perished. It entered in to the deadly draught which the old men of Ceos were condemned to drink when they became infirm, and is also said to have been the principal ingredient in the cup which Medea prepared for Theseus. The most virulent Indian puison, Bikh or Bish, is supposed to be a preparation of a species of Aconite. Dr. Wallich describes $A$. ferox as used by the native Indians to poison the water in the tanks, in order to impede the progress of a hostile army. It is also used to poison darts, arrows, and spears.

\section{THE WHITE WATER-IILY.}

(Fig. 8.)

\section{NYMPILA ALBA.}

Tirs plant belongs to another natural order or family,-Nymphæaceæ, which consists chiefly of aquatic herbs with floating leaves and solitary flowers; found in all temperate and tropical parts of the world. They have usually four sepals aud many petals in several rows, contracting gradually into stamens. The fruits are numerous, but are either imbedded into the receptacle, or combined together to form a single ovary with many cells. Nymphcec alba, the White Water-Lily, has bright, smooth, heart-shaped leaves, 
floating on the surface of the water; usually six or eight inches in diameter. The flowers are large, white, and Hoating, with yellow stigmas. It is one of the brightest ornaments of our still lakes and ponds throughout Europe, and is a favourite plant with all lovers of flowers. The flower of the White WaterLily is an excellent example of the law of morphology in plants. The doctrine that all the parts of a plant are modifications of the leaves, may be aptly illustrated by tracing the gradual changes which take place in the floral envelopes of this plant. Begin with the outermost whorl of sepals, and trace the leaf-like character gradually lessening until they become changed into perfect stamens, with petal-like anthers attached to them. The flower-stems are porous and succulent, but rapidly lose their moisture if removed from the water. The Water-Lily may be transplanted from its native home by placing the thick stems in baskets of earth, and fastening stones to them so as to keep them well under water. These stems have a bitter, astringent taste, but are quite free from any of the poisonous acrid principle of the last family of plants we met with. They have been used in dyeing a darkbrown colour. Goats and swine will eat them, and they have been used medicinally. It is, however, as an object of beauty that the Water-Lily claims our attention; and nothing can be more lovely than a calm lake on whose bosom may be seen floating numbers of these snowy nymphs. On Loch Lomond acres are covered with them; and in all the northern English lakes they are more or less abundant. Like the sacred Lotus of the Nile, the flowers rise and 
expand as the sun gains strength, and close again in the evening; sleeping as it were through the hours of darkness until called into life again by the warm rays of light.

Moore poetically describes this natural process,-

"Those virgin lilies all the night,

Bathing their beauties in the lake,

That they may rise more fresh and bright,

When their beloved sun's awake."

The stimulus of the sun's rays seems to have relation to the fertilization of the plant. The pollen, if scattered beneath the water, would be washed away and decomposed, while on the expanded raised flower it is received without injury. This is truly the object for which-

"The water-lily to the light

Her chalice rears of silver white."

And as it is with poets in sentiment, so it should be in our every-day life; each daily duty, if viewed aright, contains in it the elements of poetry, which may be made to surround the most prosaic acts of existence with beauty.

The Yellow Water-Lily, Nuphar lutea, is almost as attractive in its golden radiance as is its more modestly-attired sister.

"In golden armour glorious to behold," it forms a beautiful object on the surface of a lake or river. Other tropical species of Nuphar have wonderfullytinted blossoms, of blue and crimson.

In Demerara grows the Victoria regia, whose leaves are as much as six feet and a half across, and 
whose flowers are frequently fifteen inches in diameter. All lovers of floral beauty should give themselves the treat of seeing these magnificent flowers in the aquatic greenhouse at $\mathrm{Kew}$, or in the Regent's Park botanical gardens, where, in the season, they blossom in perfection.

\section{PRICKLY POPPY.}

(Fig. 9.)

\section{PAPAVER ARGEMONE.}

Papaver Argenone belongs to the family of Poplies,-Papaveraceæ. They are all herbs with muchdivided leaves and no stipules. The sepals are two in number, and fall off as the flower expands. The flower consists of four regular-shaped petals. The stamens are distinct and numerous. The fruit is a capsule opening in valves; the seeds albuminous, and containing a fixed oil. Papaver Argemone, the Pale Poppy, or Prickly Poppy, is not so common as the Corn Poppy, P. Rhceas; but is remarkable for its delicacy. The flowers are of a pale-red colour, with a dark spot at the base; the segments of the leaves are few and narrow, and the firuit or capsule is covered with minute bristles. There are several other species of British poppies: the common Field or Corn Poppy, P. Rhoeas; the Long-headed Poppy, P. dubium; the Rough Poppy, P. hybridum; the Opium Poppy, or $P$. somniferum. All the species exude more or less a milky juice, the narcotic properties of which are 
considerable only in $P$. somniferum. This species yields the poppy-heads so commonly used in fomentations. Opium can be prepared from the juice of the English plant, which has been used instead of foreign opium; and although not so powerful in its action, possesses the same properties.

Many are the curious legends and traditions connected with the poppy plant. Theocritus tells us that the silken petals of the poppy prove talismans for Cupid, thus :-

"By a prophetic poppy-leaf I found

Your changed affection; for it gave no sound, Though in my hand struck hollow as it lay, But quickly wither'd like your love away."

In classic lore, the poppy was sacred to Ceres, though our modern notions of agriculture would rather regard it as an intruder into her domains.

Of all the strange and baneful, as well as beneficial effects of the poppy-juice or opium, we can hardly speak here. As a medicine it is most valuable, if carefully administered, and it has often soothed and palliated the sufferings of humanity. As a hurtful and sensual indulgence, its effects are well known; iu Eastern countries, perhaps, better than our own. The fascination of this pernicious habit, and its terrible results, are vividly described in a popular work, "Confessions of an English Opium-eater." 


\section{YELLOW HORN-POPPY.}

(Fig. 10.)

\section{GLAUCIUM LUTEUM.}

Tins plant reminds us of our seaside holiday-time, of sandy beaches and rolling waves; and as with no objects are mental associations more vivid than with flowers, the sight of a plant but rarely met with, must recall to our minds the circumstances under which we first saw it. Perhaps a first visit to the sea-beach, or to some well-loved spot, and all the delicious refreshment of the sea-breeze, the rest and repose which steal over the most active mind when listening to the tune of the waters, is in a measure brought back again, as we see, even in its dead and dried state, the well-remembered plant of the seashore. Our Yellow Horn-Poppy is the most striking and remarkable of our seashore plants, and cannot fail to arrest the attention of the most casual observer, in a position where so little vegetation flourishes. The foliage is of a pale sea-green colour, which botanists term glaucous: hence its scientific name. It is rough, with short bristles; the pods or horns are from six to ten or twelve inclies long, crowned by the spreading lobes of the stigma. When we see this pretty plant, it is interesting to remember the history of Glaucus, after whom it is named. He was the son of Neptune and of Nais, a sea-nympl, but lived on shore. His nature, however, had some influence on his habits, and he was fond of fishing. One day, 
having been very successful in his sport, he laid his scaly prize on a neighbouring marsh, when to lis great surprise they began to nibble the green grass, and then

$$
\text { "Sudden darting o'er the verdant plain, }
$$

They spread their fins as in their native main, Left their new master, and regain'd the sea."

Amazed at what he saw, Glaucus resolved to test the power of the herbage in lis own person; and no sooner had he bitten it, than his hereditary aquatic propensities seized him, and into the ocean he leaped, when, for his faith and courage, he was received as a denizen among the sea-gods.

In their domain he still shows his royal descent by wearing a golden robe; and yet, from old affection, high above it he bears his favourite long and curved fishrod, with its point bent, as if a captive fish ever strained it. Glaucus never goes far out to sea, but rather frequents the shores and cliffs; for Scylla, whom he loved, was turned into a rock, with howling waves around her; and his faithfulness retains him still close to her side.

The Yellow Horn-Poppy is the "squats" of the Portland Islanders.

\section{DYER'S WOAD.}

(Fig. 11.)

\section{ISATIS TINCTORIA.}

Our next specimen belongs to another and very extensive and useful family of plants,-Cruciferæ or 
Crossworts. The species are herbs, or rarely undershrubs, with alternate leaves and no stipules; four sepals, four petals of equal size, or two on the onterside layer. The stamens are six in number, of which two are generally shorter, or sometimes altogether absent. The fruit is a pod, divided into two cells by a thin partition, from which the valves generally separate when ripe. When long, it is called a silique, and when short, a silicle.

Isatis tinctoria preserves the general characteristics of the family. The stem is from eighteen inches to two or three feet high, branched in the upper part. Its long leaves are smooth and coarsely toothed and stalked, the pods hanging on slender stalks downwards. The flower is of a yellow colour.

The specific name tinctoria signifies its use in dyeing or staining. From it was undoubtedly obtained the blue dye or woad with which the Ancient Britons stained their skins.

When the arts of civilized life were not practised, this substance supplied, according to the poet Garth, all the requirements of a fashionable toilette.

"In times of old when British nymphs were known Tolove no foreign fashions like their own, When dress was monstrous, and fig-leaves the mode, And quality put on no paint but woad."

At the present day this plant is used by dyers, not on account of its own blue colour, but as a mordant for other colours. Its colouring principle seems to be identical with indigo. It is cultivated in Bedfordshire, Northamptonshire, and Sumersetshire. 


\title{
THE COMINON WHITLOW-GRASS.
}

\author{
(Fig. 12.) \\ DRABA VERNA.
}

Draba verna, a cruciferous plant, is one of our earliest spring flowers; and as soon as the bright days of March and April tempt us out into the fields and lanes, we may look for it on dry walls and banks, with its little stalk of white flowers. It is a small annual plant, and lasts but for a few weeks; the leaves are all towards the base, ovate or oblong. The seed-pods burst open in the month of May, and scatter the seeds into the ground, where they lie securely till the next season. The tiny flowers droop at night to keep the stamens from the chilly dews of the early spring. The common name, Whitlow-grass, is given on account of the use of the leaves as a poultice in those unpleasant swellings.

It belongs to the genus Erophila of De Candolle, a pretty name, expressive of its early appearance.

\section{COMMON WATER-CRESS.}

(Fig. 13.)

\section{NASTURTIUM OFFICINALE.}

Nasturtium officinale,-also known as Sisymbrium Nasturtium, the Common Water-cress,-should 

be familiar to every one, as belonging to the family Cruciferæ. It is very likely to be confounded with a poisonous plant with which it grows, the Fool's Cress, ais it is called (Sium nodiflorum). From this it may always be distinguished, and, in fact, from all other Umbelliferæ, by the petioles of the leaves not forming a sheath round the stem. In addition to the characters of the genus, the Water-cress is known principally by the form of its leaves. The leaf is composed of from five to seven leaflets, which are arranged opposite each other on a common leaf-stalk with a terminal leaflet. The leaflets are somewhat heart-shaped and slightly waved or toothed; they are succulent and therr surface is smooth. The terminal leaflet is always the largest. The petiole or leaf-stalk does not in any manner embrace the stem. The flowers are white, and the pods, when ripe, are about an inch long. It is a native of rivulets throughout the world, and is very plentiful in our own country. The ancient reputation of this plant as an article of food, valuable both for its pleasant pungent taste and its antiscorbutic properties, is well founded. Recent writers on the subject of diet have shown that in partaking of fresh uncooked vegetable food in the shape of salads or fruit, we are obtaining those salts of potash and other. constituents so necessary to lealth, which in the prucess of cooking are dissolved away.* Water-cresses are said to contain iodine.

No better vehicle for the introduction of these

* See Dr. Lankester's Lectures on Food. London: R. Hardwicke. 
important substances can there be than fresh bright water-cresses; and our old friend Gerarde's notion of their value presages all the modern discoveries as to their virtue. He says that the eating of watercresses restores their wonted bloom to the cheeks of sickly young ladies. He might have added that a walk to the running stream where they grow would enhance the effects of the remedy: So large is the consumption of water-cresses in London that they are cultivated by market-gardeners to a great extent by means of artificial water-supplies; but none are so delicious as those from natural streams. Our popular street-cry has been rhymed by Swift thus :-

"Fine spring water-grass, fit for lad or lass."

The name cress has, according to writers, many origins. One says it signifies water cross, from its cruciate flowers. Chaucer employs the Saxon word kers (cress) to signify anything worthless :-

"Of paramours ne raught he not a kers."

From which, perhaps, is derived the phrase of not caring a curse for a thing. Nasturtium is a name given to all these biting plants, each being a nasus tortus, or nose-twitcher. Pliny records that they put the nose into convulsions. Long ago the refreshing nature of these plants as food was recognized, and there is a Greek proverb, "Eat cress to learn more wit." Knowing, as we now do, the influence of the physical over the mental, we can rationally understand the proverb.

There are several other species of Nasturtium 
native in England;-the Creeping Cress, $N$. sylvesire or $N$.palustre; the Water-rocket, $N$. terrestre; and the Water-radish, $N$. amphibiums.

\section{THE ROCK ROSE, OR ROCK OIST.}

(Fig. 14.)

\section{HELIANTHEMUM VULGARE.}

Our next plant belongs to a new family,-Cistacea. The characters of the order are that the species are shrubs or herbs with opposite, or in a few exotic species, alternate leaves, with or without stipules, generally smelling fragrantly. The petals are usually five in number, broadly spreading, the sepals three, nearly equal, overlapping each other in the bud, with or without two smaller outer ones.

The species figured H. vulgare, is a low undershrub, with a woody stem; the leaves have stipules; the flowers are of a bright-yellow colour, broadly spreading, and blooming from May to September. It is found in dry meadows and pastures throughout Europe and western Asia, and is not uncommon in Great Britain. The Rock Rose, or Cistus of our gardens, is a variety of this species. 


\section{SWEET VIOLET.}

\section{(Fig. 15.) \\ VIOLA ODORATA.}

The Sweet Violet is a favourite with everybody, and scarcely requires description to be recognized. It is, however, interesting to know that it belongs to the family Violaceæ, and to the only European genus of that family. It has five petals of unequal shape and size, the lower one being drawn out into a kind of spur. There are five sepals, and the stamens are connected together; two of them with curious ear-like appendages. The flowers are of a purplish colour, nodding. On the stem we have an example of what are called bracts. The leaves grow at the base of the plant, with rather long stalks, and are broadly heart-shaped. There are several British species of this genus, but our sweet-scented violet, and the pretty blue dog-violet, which is inodorous but very attractive, are those most worthy of notice. Who does not welcome the first violets in the early spring, "gleaming like amethysts in the dewy moss;" and there is no land where these pretty flowers grow in which their praises have not been sung. We must all have felt the power of perfumes in recalling to the memory images and scenes of past years, before these lines were written,-

"The smell of violets hidden in the grass

Poureth back into my empty soul and frame The times when I remember to have been

Joyful and free from blame." TenNyson. 
Not only is the violet celebrated for its beanty, but for its uses and for its mystic powers. Violet roots and violet flowers have been used as remedies in all sorts of diseases. The Athenians were noted for their love of these flowers, and they were reputed to "moderate anger," to procure sleep, and to comfor't and strengthen the heart. At the present time the root is used as an emetic. Pliny prescribes a liniment of violet roots and vinegar for gout and disorders of the spleen. The violet is certainly a classical plant. It was a favourite with the old Greeks. Homer and Virgil both mention it frequently, and Shakspeare alludes to a very old superstition, when he says, -

\author{
"Lay her i" the earth, \\ And from her fair and unpolluted flesh \\ Miry violets spring."
}

\title{
SUNDEW.
}

(Fig. 16.)

\section{DROSERA ROTUNDIFOLIA.}

A very pretty and curious little plant is the Sundew, or Drosera rotundifolia; and it is found where we should least look for beauty : in bogs and morasses, in the damp corners of heaths and wildernesses, we descry the ruby points of the leaves of this lovely little plant sparkling amid emerald-green moss-tufts. It is the type of the family Droseracere. A small flower-stalk, from two to six inches in height, bears on 
the top the few little white flowers which expand in the sunshine. The leaves grow very low down, close to the ground, and are of a round shape, and thickly covered with the minute red hairs, each of which secretes a drop of fluid, which sparkles in the sunshine like diamonds. These drops of fluid are of a somewhat glutinous nature, and are apt to entrap unwary insects that happen to alight on the leaves. It is somewhat dificult to find the Sundew fully expanded; the best way of seeing it in all its beauty, is to remove a tolerably large portion of the plant with a trowel, and then, placing it in a saucer, surrounded with the damp green moss in which it grows, cover it over with a hand-glass, supply it freely with water, and you have as pretty a little Ward's case as can be imagined, and an interesting subject for botanical study likewise. It is to be found, by careful searching, on Hampstead Heath, on Wimbledon Common, and in most boggy, heathy districts. It is an acrid and caustic plant, and has been supposed to cause the rot in sheep. It had once a reputation as a cosmetic, and is said to burn away corns and warts. It also curdles milk, and has been frequently used in the dairy for that purpose. This is the plant of which Burton, in his "Anatomie of Melancholy," says "that Beruardus Ponottus prefers his herba solis before all the rest of herbs in this disease (melancholy), and will admit of no lierb upon the earth to be compared with it." In Italy it is used for making the liquor called Rossoli.

There are other species of Drosera in the British Flora, which possess dyeing properties, as may be 
seen when they are dried in the herbarium, by the red colour they communicate to the paper.

\title{
THE CARNATION, OR CLOVE PINK.
}

\author{
(Fig. 17.)
}

\section{DIANTIIUS CARYOPHYLLUS.}

Tuis plant is a native of the South of France, but is found wild on old walls in Kent and Norfolk. It belongs to the family Caryophyllaceæ, and is one of a beautiful genus of plants, all of which are sweet-scented and showy. Mr. Babington describes six species of Dianthus as natives of Great Britain. The clove pink has solitary flowers; the scales of the calyx are much shorter than the tube of the corolla; the leaves have smooth margins; the petals are toothed, ovate, and smooth; the stem branching, long, and procumbent; the seeds nearly flat, and the flower-stem from twelve to eighteen inches high. The flowers of the genus are of all colours, excepting blue; in the British species they are of a pale pink, and in all cases fragrant. The flowers of the Clove Pink are used to give colour and fragrance to a syrup used in medicine. A small variety of this species is known by the name. of Picotees. 


\section{THE RED CAMPION.}

(Fig. 18.)

\section{LYCHNIS DIURNA.}

The Red Campion, Lychnis diurna, belongs to the family Caryophyllacer. It has oblong leaves, usually pointed, tapering to the base, the lower ones stalked. The flowers are few, in loose branches, of a red colour, opening in the morning; the calyx forming a sort of capsule composed of two divisions, or teeth, which curve backwards. The capsule thus formed becomes globular as it ripens. This pretty plant is found in moist shady woods and hedge-banks all over Britain. It flowers all through the summer, beginning early in the spring. The other British species are known by the names of Scarlet Lychnis, Ragged Robin, and White Campion. The Corn Cockle is also a pretty plant belonging to this fanily, which is found blossoming in cornfields from June to September.

\section{F L A X.}

(Fig. 19.)

\section{LINUM USITATISSIMUMR.}

ONE of the most valuable of our native plants is the Flax Plant,-Linum usicatissimum; and in the 
delicate little blue flowers and fragile-looking stem the uninitiated would little imagine the living of thousands and the chief manufacture of a great country to lie concealed. It is a tall, erect anuual plant, with alternate narrow-pointed leaves, and flowers of a rich blue colour, arrayed in a loose terminal bunch. The fibre of the plant is woven into linen, and the seeds are valuable on account of the mucilaginous nature of their external coating, and for the oil they contain, which is prized for burning and as a drying medium in the arts: the oilcake made from the seeds is an extensive article of food for cattle. Flax is chiefly cultivated in Ireland, and from a very early time the importance of its culture was recognized in the economy of this country. In 1750 , Sir William Temple wrote a treatise on the subject.

Microscopic examination has clearly proved that the mummy-cloth of Egypt is made of linen fibres, and not, as was once supposed, of cotton. Herodotus and Plutarch tell us that it was not permitted to any Egyptian priest to enter a temple unless he wore a linen garment. By the Greeks, linen was used in the time of Herodotus; possibly not produced by the same species as the one now grown for the purpose, but undoubtedly the fibre of a species of Linum. We have four British species of this genus. None are of any importance but the one we have selected. The Welsh species, or the fairy flax, is an elegant little mountain species, which is remarkable for its beauty and grace, and has a medicinal reputation in its native mountain districts. The exquisite deli- 
cacy of the flax plint is aptly pictured by Coleridge :-

"The unripe flax,

When through its half-transparent stalk at eve

The level sunshine glimmers with green light."

THE TREE MALLOW, OR SEA LAVATERA.

(Fig. 20.)

\section{LAVATERA ARBOREA.}

THE genus Lavatera was named in honour of Lavater (a physician in Zurich, not the celebrated physiognomist of that name), and belongs to the Mallow family, Malvaceæ. The flowers in all the genera of this family are twisted in the bud, the calyx composed of five divisions, with three or more bracts at the base, forming an outer calyx. The species we are now considering has a woody stem, something like that of a cabbage, with thick, hard, flowering branches. The leaves are on long stalks, with seven, five, or three lobes, and soft as velvet. The flowers are mostly in pairs, of a pale purple-red colour, with dark blotches at the base of the petals. It blossoms from July to October, and is found on seaside rocks throughout Europe; in Britain, chiefly on the south and west coasts of England and Ireland, especially in the Isle of Wight, and on the Bass Rock in the Frith of Forth. 


\section{THE MUSK MALLOW.}

(Fig. 21.)

\section{MALVA MOSCHATA.}

Tuis plant belongs to the family Malvacex. The genus Mallow is a very favourite and well-known group, and most of us may recall, when children, the delight with which we have sought for the plants, in order to secure the much-prized "cheeses" or fruits of the mallow. The Musk Mallow has a tough woody root, and an upright partially-branched stem. The root-leaves have long leaf-stalks, with rounded limbs cut into three or five lobes. The stem-leaves are much more deeply cut and lobed than the root-leaves. The whole herbage is more or less hairy. The flowers are large, rose-coloured, or rarely white, crowded together at the top of the stem and branches. The calyx consists of two whorls, the outermost composed of three acute sepals, the innermost five-toothed. The corolla has five wedge-shaped petals jagged at the end. Were this pretty plant less common than it is, it would, perhaps, meet with more admirers; but the extraordinary perverseness of the human mind leads us to admire most that which is least attainable, and to hold an everyday object in slight estimation. The musk-like scent of the particular species of mallow we have selected distinguishes it from the rest, although it be but slight. The Musk Mallow, like the anemone, closes its petals at night. In floral 
language it is regarded as the emblem of a sweet, mild disposition, and we read that it was customary with the ancients to plant musk mallows around the graves of their departed friends. The common mallow, $M$. sylvestris, yields, when boiled, a plentiful tasteless mucilage, which is used in some cases as a medicine.

\section{MARSH MALLOW.}

\section{(Fig. 22.)}

\section{ALTIIEA OFFICINALIS.}

This species is also a Malvaceous plant, but belongs to a different genus. Marsh Mallow,-Althcea officinalis, is a common European plant, and is often found in marshes, especially near the sea, in great abundance. It is a perennial, with a carrot-shaped, white fleshy root, as thick as the thumb, and a foot or more long. The stems are two or three feet high, covered all over with a soft down, which is also found on the leaves, and gives them a hoary appearance. The leaves are a little heart-shaped and three-lobed, The flowers are not large, of a pale rose-colour, and appear in very short clusters from the bosom of the leaves; the calyx is five-toothed, and surrounded with practs. The whole plant, and particularly the root, abounds in mucilage; the demulcent lozenges sold in the shops under the name of Pâte de Guimauve, are made of marsh mallow, and a few years ago there was an ointment commonly used, which may still be in repute for aught we know, called Marsh Mallow Oint- 
ment. The hollyhock of our gardens is a species of Althæa from the Mediterranean. It is found wild in China.

\section{THE LARGE-FLOIVERED HYPERICUM, OR ST. JOHN'S WORT.}

(Fig. 23.)

\section{IIYPERICUM CALYCINUM.}

'Turs is a showy plant, belonging to the family IIypericacer. It was brought to England by Sir G. Wheeler in 1676 , from its native woods near Constantinople. It has been long cultivated in our gardens, and is found wild in bushy places in England and in Ireland. This species of St. John's Wort has a creeping woody rootstock, the stems scarcely a foot high, simple, and branching at the base only, with large oblong leaves, green and smooth, having very small clear spots on their surface. The flowers are of a bright yellow colour, three or four inches in diameter, with one or two on the top of cach stem; in our gardens it is more luxuriant, and produces five or six. There are thirteen British species of this genus, and one hundred and seventy-two are enumerated by De Candolle as growing in various parts of the world. They are all known as St. John's Worts, and most of them are worthy of cultivation. The hardy herbaceous kinds will thrive in any common garden-soil, and are easily propagated by dividing the roots or by seeds. Those 
which require the greenhouse will thrive best in a mixture of loam and peat, and strike root readily under a hand-glass.

The Hypericum perforatum, the perforated St. John's Wort, was one of the flower's gathered by our forefathers to be thrown into the bonfires which were kindled in London on the eve of St. John. In many parts of France and Germany the peasants still gather its golden blossoms, and hang them with much ceremony in their windows and doorways, as a charm against evil spirits, storms, thunder, and all calamities. This custom probably arose from the misinterpretation of some medical writers, who, believing in its virtue as a remedy in maniacal disorders, called it Fuga Domonum. It was at one time worn about the person in Scotland as a protection against witcheraft and enchantment.

\section{GRAS OF PARNASSUS.}

(Fig. 24.)

\section{PARNASSIA PALUSTRIS.}

Here we are among the gods; but surely this pretty plant has mistaken its habitation, for we find it in marshy, boggy places, and scarcely ever on elevated land. The Grass of Parnassus, or Parnassia palustris, belongs to the same family of plants as our little Sundew,-Droseracece; and it is often found in the same localitics. Why it is called a grass we cannot 



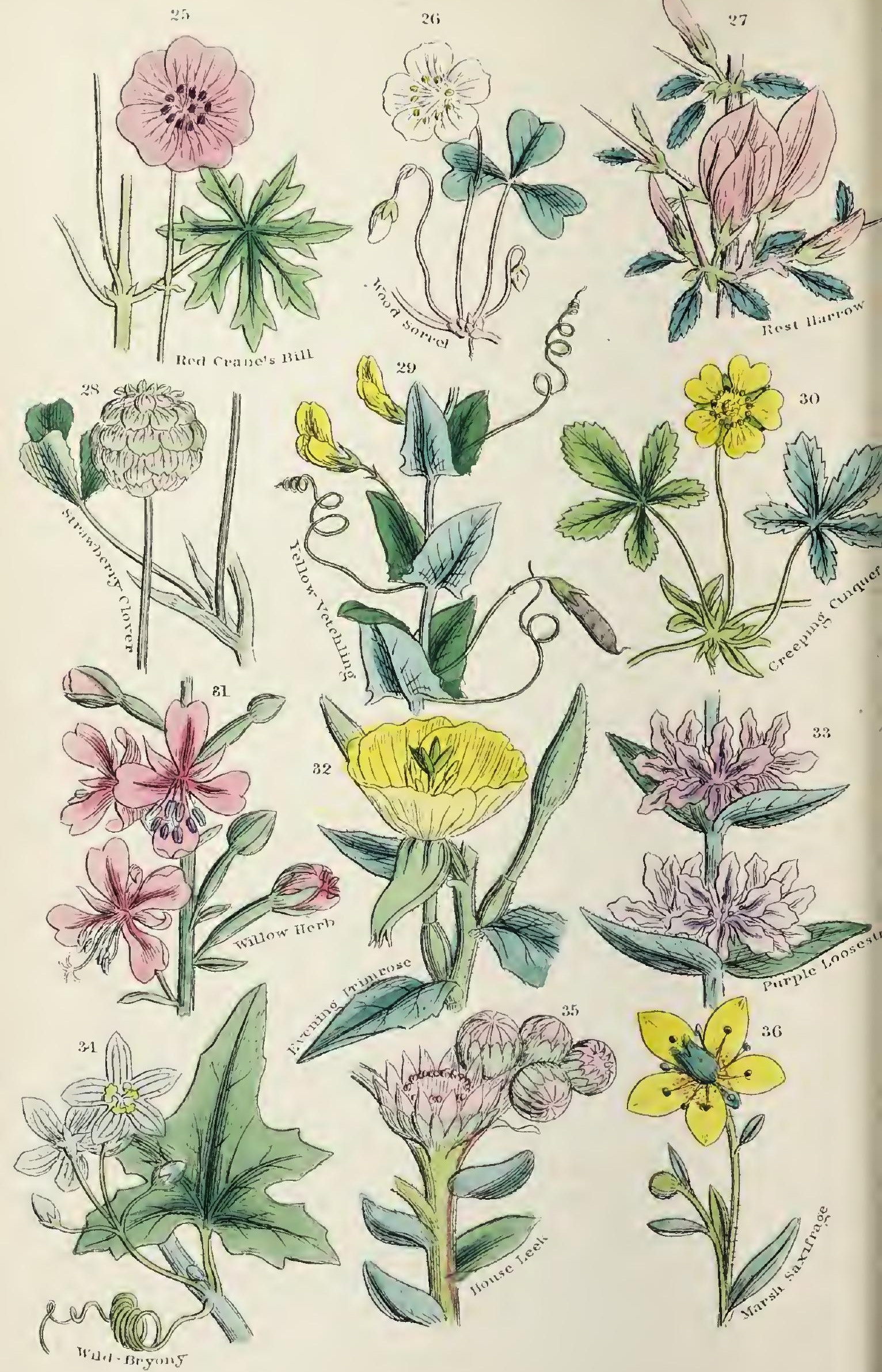


imagine ; for with its delicately-coloured flowers, beantifully netted, it does not resemble the family of grasses at all. The leaves around the roots are on long stalks, while here and there a leaf clasps the flowerstem. Each flower-stalk produces but one flower, which has curious fringed scales, which lie around the centre, and are the nectaries; a little waxlike gland exists at the tip of each hair. In former times, this flower was called the Noble Liverwort, and was doubtless considered a remedy in diseases of the liver. It is the only British species of the genus. Sir William Hooker tells us that this elegant plant, if plunged into water in a garden-pot, surrounded by a ball of its native earth, will continue to blossom for many weeks.

\section{RED CRANE'S-BILL, OR THE BLOOD GERANIUM.}

(Fig. 25.)

\section{GERANIUM SANGUINEUM.}

The Blood Geranium grows in great profision on our western limestone coasts, and is one of the most attractive of the species. The family to which it belongs is Geraniaceæ; of which the characters are well preserved in the genus Geranium.

The plants known by this name must not be confounded with the so-called geraniums of our gardens, which, though of the order Geraniacer, belong to the 
subdivision Pelargonium. The five petals of our true geranium are of the same size, while the inferior petals of the pelargoniums are smaller than the other two, and of a different character.

Geranium sanguineum is known by its numerous stems, about a foot long, leaning downwards, or sometimes upright, with spreading hairs. The peduncles are mostly single-flowered; the carpels smooth, crowned with a few bristles; the leaves nearly round, seven-lobed. The flowers are large, of a dark-purple colour; the sepals hairy, with a fine point. The whole plant somewhat resembles the mallow in appearance, and there is an Eastern notion that geraniums were at first simply mallows, until Mahommed, delighted with the fine texture of a shirt made for him of mallow fibres, turned that plant into the more beautiful geranium; or some assert that his shirt being spread to dry on a mallow plant, the transformation was discovered on taking it up. There are above a dozen British geraniums; the most common one, probably, being G. Robertianum, the Herb Robert, which has a medical reputation. The root of $G$. maculatum, or Alum-root, is a really powerful astringent, containing more tannin than catechu or kino. In North America it is employed as a remedy in sore throat among children. The beautiful red colour assumed by the leaves in dyeing may have been suggestive of their efficacy in arresting hæmorrhages; the fancy is scarcely more absurd than our modern doctrine "that like cures like." 


\section{THE WOOD SORREI.}

(Fig. 26.)

\section{OXALIS ACETOSELLA.}

The Wood Sorrel, Oxalis acetosella, belongs to the same family as the Geranium,-Geruniaceoe. It is easily recognized by its three delicately green leaflets, with longish stalks, marked with a darkish crescent in the centre, veined, and its lovely white flowers, which at first sight resemble the wood anemone. There are few walks or shady woods where, in the early spring, the bright half-folded green leaves of this pretty little plant may not be found. The tiny white flowers, with their delicate purple veins, are called by the Welsh "fairy bells," and are believed to ring the merry peals which call the elves to "Moonlight dance and revelry." The whole plant abounds in an acid cooling juice, which contains oxalic acid. An infusion of the leaves is frequently administered as a cooling drink in Russia, and the salt prepared from it is used under the name of "salt of sorrel," to remove the stains of ink and iron-mould from linen. Among the Druids, its triple leaflets were regarded as a mysterious symbol of a trinity, the full meaning of which was involved in darkness. So, too, St. Patrick chose this leaf as his symbol to illustrate the doctrine he sought to teach, and converted many by the apt use of an illustration derived from a plant already sacred in the eyes of his hearers. The original shamrock was 
undoubtedly the Oxalis; though the name became applied to all sorts of trefoiled plants. In all ages, the trefoiled leaf has been regarded with veneration, especially when, departing from its usual form, it is found with four leaflets. The old song, "I'll seek a four-leaved Shamrock," tells of the fairy spells to be woven with its enchantment.

The wood sorrel approaches nearest of all our native plants to a sensitive plant, not only closing its petals and folding its bright green leaves at sunset, and with every change of atmosphere, but even if the stem be rudely or repeatedly struck. In a flower-sancer, or pan covered with a glass shade, this pretty plant forms a lovely object; and we have frequently seen it blossoming year after year in a Ward's case or under a hand-glass, covering the space given to it with its delicate white blossoms. An old Welsh proverb says-

"Three things let no one trust such as shall dislike them,The scent of trefoils, the taste of milk, the song of birds."

\section{THE REST-HARROW.}

(Fig. 27.)

\section{ONONIS SPINOSA.}

This plant belongs to the Pea-flower family, or Leguminosæ. It is a low spreading little shrub, with hard, tough, trailing roots, which often retard the progress of the plough, while its numerous and thorny 
branches are so great an impediment to the action of the harrow in turning up the ground, as to lave obtained for it the common English name of RestHarrow. Frequently the whole plant is clothed with sharp hairs or prickles, but sometimes they are quite soft, and the plant smooth, according to the soil in which it grows. The leaflets are oblong or obovate. The flowers are solitary, on short branches of a pink colour, sometimes streaked with a darker shade. It is often very abundant on the sandy cliffs near the sea-shore. This little plant has its uses; for although in its thorny state no animal but the cionkey will eat it, yet on better soils it mingles with the pasture, and is relished by cows, sheep, and goats. The roots are succulent and sweet, and have been considered good as a pickle. In the time of Queen Elizabeth they were often brought to table in this forls.

\section{THE STRAWBERRY CLOVER.}

(Fig. 28.)

\section{TRIFOLIUM FRAGIFERUM.}

Every one must have noticed, and perhaps gathered, this plant, wondering whether it were fruit or flower, scarcely recognizing in the tiny red heads, the closelypacked flowers surrounded by an involucre of bracts. It belongs to the family Leguminosa, and is found chiefly in damp meadows and in moist places near the sea. In the neighbonrhood of London it is not 
uncommon. There are many British species of clover. Mr. Babington describes twenty-one. The white or Dutch clover is very largely cultivated, and is now often used as the representative of the true shamrock, or three-leaved plant of Ireland. The original mystic plant was doubtless the Oxalis, of which we have before spoken. Leaves of this character have from a very remote period been regarded with superstitious veneration.

"The holy trefoil's charm"

was considered potent against all manner of evil.

\section{THE YELLOW VETCHLING, OR YELLOW}

\section{PEA.}

(Fig. 29.)

\section{LATHYRUS APHACA.}

Tirs plant is a common European field plant, belonging to the natural order Leguminosæ. It is a little smooth pale-green annual, branching from the root into several weak stems, either lying on the ground or climbing by means of numerous alternate simple tendrils, each of which springs from between a pair of large stipules of a broad arrow-shape. There are no true leaves or leaflets, except now and then near the root. The flowers are solitary on simple stalks, small, drooping, and lemon-coloured. The bracts are in pairs, oval-shaped; the teeth of the calyx loug 
and lanceolate, ribbed. The pod is about an inch in length, smooth, and containing about six round seeds, which are somewhat narcotic, and produce excessive headache if eaten abundantly when ripe. In their young and green state they may be eaten like green peas without inconvenience. L. sylvestris, the everlasting pea, is a well-known and pretty species of the same genus. It is cultivated in our gardens, and is often found wild in England. The genus Lathyrus is nearly allied to Vicia, the true vetches, of which there are many very pretty British species; Vicia cracca, the tufted or purple vetch, is one of the most attractive. We can imagine that it must have been this pretty flower which suggested to Sir Walter Scott these lines :-

"And where profuse the wood-vetch clings

Found ash and elm in verdant rings,

Its pale and azure pencill'd flower

Should canopy 'Titania's bower."

\section{CREEPING CINQUEFOIL.}

(Fig. 30.)

\section{POTENTILEAA REPTANS}

Tirs is a common British plant, belonging to the fimily Rosacer, and is found on heaths, moors, and open pastures thronghout Europe. The stems are prostrate, and creep along the ground, rooting at the joints for a considerable distance. The stipules are ovate, and mostly entire; the calyx hairy. 'The 
leaves are stalked with five obovate or oblong coarselytoothed leaflets. The petals are large, of a bright yellow colour, mostly five in number, sometimes four. This pretty plant is found on the borders of meadows, edges of woods and hedges throughout Europe and Asia. It greatly resembles the common Tormentilla, and is often mistaken for it. The latter is an astringent plant, and has been used medicinally; also for tamning in the Western Islands of Scotlind and the Urkineys.

\section{WILLOW-HERB, OR CODLINS AND \\ CREAM.}

(Fig. 31.)

\section{EPILOBIUM ANGUSTIFOLIUM.}

A prlfe-pie Plant, as it is called, is a very handsome plant, belonging to the family Onagrariæ. It has a creeping root, an erect nearly simple stem, slightly hoary, but not hairy, like another species, $E$. nilobium livisutum. The leaves are shortly stalked, lanceolate, entire, or with very minute distinct teeth. The flowers are large, purplish red, in long bunches; the petals are slightly unequal, entire, and spreading from the base ; the stamens and styles inclined downwards. The stigmas are deeply four-lobed. The pod is from one to two inches long, more or less hoary. It is found in mountains, woods, and meadows, in Europe and Siberia. In Great Britain it is found in noist 
places in the north of England, and in the sonth of Scotland. It has crimson, inodorous flower's, with blue pollen. It is a showy plant, and is often transplanted into gardens, where, however, it must be carefully watched, or its creeping roots will encroach on other plants. The down of the seeds furnishes that soft downy substance which, either alone or mixed with cotton, is often woven into stockings, gloves, and such things. The leaves are used in the adulteration of tea, or as a siblstitue for it. Its young root-stalks and suckers are boiled and eaten; and the Kamtschatkans make a beer from an infusion of the plant. The pith is dried and boiled, and on being fermented is converted into vinegar.

The name Willow-herb is given probably fiom some slight resemblance in the outline of the leaves to those of a species of willow; and perhaps, too, the situations in which the greater part of the species grow being near the water, or in it, may account for it.

Gerarde says the willow-herbs stop bleeding, heal wounds, and drive a vay snakes, gnats, and flies.

\section{THE EVENING PRIMROSE, OR COMMON}

\section{CENOTHERA.}

(Fig. 32.)

\section{ENOTHERA BIENNIS.}

CEnothera biennis belongs to the same family as the willow-herb,-Onagraria. It is a biennial, with 
ovate, lanceolate, flat, toothed leaves, a rough hairy stem; the petals longer than the stamens, and about half as long as the tube of the calyx. The flowers are large, numerous, and of a bright yellow colour, emitting a slight fragrance. They close in the bright daylight, and open themselves as the sun goes dowu: hence their name. It is found abundantly on the Lancashire coast, and covers several acres of ground near Woodbridge in Suffolk. The Suffolk poet Bernard Barton has immortalized this, his native flower, in some beautiful lines, which we cannot refrain fiom quoting here :-

Fair flower that shunn'st the glare of day,

Yet lov'st to open, meekly bold,

To evening's hues of sober grey,

Thy cup of paly gold.

I love to watch, at silent eve,

'Thy scatter'd blossoms' lonely light,

And have my inmost heart receive

The influence of that sight.

I. love at such an hour to mark

Their beauty greet the night-breeze chill, And shine 'mid shadows gathering dark The garden's glory still.

For such 'tis sweet to think awhile,

When cares and griefs the breast invade :

In friendship's animating smile,

In sorrow's dark'ning shade.

Thus it bursts forth like thy pale cup,

Glistening amid its dewy tears,

And bears the sinking spirit up

Amid its chilling fears. 
But still more animating far,

If meek religion's eye may trace,

E'en in thy glimmering earth-born star

The holier hopes of grace.

The bope,- that as thy beauteous bloom

Expands to glad the close of day,

So through the shadows of the tomb

May break forth mercy's ray.

The pretty plant which suggested to the mind of our Quaker poet these beautiful thoughts is the only native species. It is sometimes called the Tree Primrose. The roots are eatable, and were formerly taken after dinner to flavour wine, as olives now are; therefore, the genuine name was changed from Onagra, the Ass Food, to Enothera, the Wine-trap. We are not sure whether the change was necessary for such as need an incentive to imprudent potations.

\section{PURPLE LOOSE-STRIFE.}

(Fig. 33.)

\section{LYTHRUM SALICARIA.}

This is a showy plant, belonging to the family Lythraceæ. It has a perennial root-stock, with short annual erect stems, two or three feet high, slightly branched, glabrous, or softly downy. The leaves are of a dark-green colour, opposite, or sometimes in threes, sessile, clasping the stem at the base, lanceolate and entire, from two to three inches long. The flowers are of a reddish-purple or jink colour, in whorled, leafy spikes. It is the Lysimachia of Pliny, 
a name which is applied to the Yellow Loose-Strife of our hedges. Our word Loose-Strife is a simple translation of this Latin word. A strong decoction of this plant acts as an astringent, as it contains tannic acid.

\section{WILD BRYONY, OR RED BRYONY.}

\section{(Fig. 34.) \\ BRYONIA DIOICA.}

A puANT belonging to the Cucumber family,Cucurbitacex, must not be confounded with the Black Bryony, Tamus communis, which is a very different plant, and about which we shall hear presently. It has a thick, tuberous, perennial root-stock, sometimes branched, the annual stems climbing to a great length; it is rough with minute hairs, containing an acrid juice, and emitting a sickly smell when drying. The tendrils are simple or branched, and spirally twisted. The leaves are divided into five or seven coarsely-toothed lobes, of which the middle is the largest. The barren and fruitful flowers are on the same plant, but on different stalks. The barren flowers are placed in small bunches, several together, and are of a pale-yellow colour; the fruitful flowers are much smaller, generally two together, nearly round. The berries are red or orange, about four lines in diameter, containing several flat seeds.

It is a very common plant in hedges and thickets in England, but it is not found in Scotland and Ireland. 


\section{7}

\section{HOUSE LEEK.}

(Fig. 35.)

\section{SEIPERVIVUM TECTORUM.}

House LEEK, Sempervivum tectorum; so named from its tenacity of life; from semper and vivo, always living. The little plant known by this name belongs to the fumily Crassulacer. There is but one British species. The foreign varieties are some of them very elegaut, and are grown in gardens aud greenhouses. Our own species was originally a native of the Alpine and sub-Alpine regions of Central Europe, but it has now found its way to the tops of old walls, and the thatched and tiled roofs of the houses of all the cuuntries of Europe. It is frequently called Jupiter's Eye, Bullock's Eye, or Jupiter's Beard. It has very thick and fleshy leaves, the lower ones, one to one inch and a half long, ending in a small point, and bordered by a line of short stiff hairs. The flowers are pink, arranged along the spreading branches of the cyme, without stalks. The petals are twelve in number, smooth within, fringed with delicate hairs at the edges and on the outside.

This plant is very closely associated with the Stonecrops or Sedums, and shares with them virtues both supernatural and physical. It is considered lucky by the Welsh peasantry to have their roofs covered with these plants; they are believed to protect the house fiom the ravacres of the elements, and to insure the 
prosperity of the inmates. Pliny mentions the stonecrop as infallible for procuring sleep; but to produce this effect the plant must be wrapped in black cloth, and carefully introduced under the pillow of the patient without his knowledge. The juice of the House Leek, when mixed with cream or applied by itself, is said to give relief in burns and other external inflammations. Its vitality is such, that it survives the longest droughts, and the rapidity with which it reproduces itself, even after the roughest treatment, is surprising. Its power of continuing to live under the most adverse circumstance is owing to the facility with which it abstracts carbonic acid gas from the atmosphere. This substance is the food of all plants, and it is thus that they take out of the air and appropriate to their own nourishment what would be injurious to man.

\section{THE MARSH SAXIFRAGE。}

(Fig. 36.)

\section{SAXIFRAGA HJRCULUS.}

The Saxirrages are called also Stone-breaks, from the wonderful manner in which the fibres of their roots penetrate the strongest rocks and most unpromising soils. The genus Saxifraga is the type of the family Saxifragaceæ. Our example is the Yellow Marsh Saxifrage. The stem is solitary, from four to eight inches long, sometimes covered with rusty hairs. 


\section{-}


ond

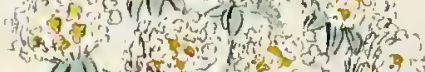

M. N of

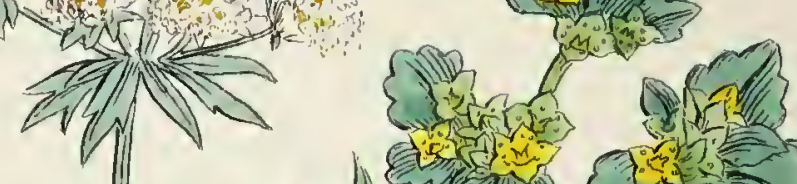
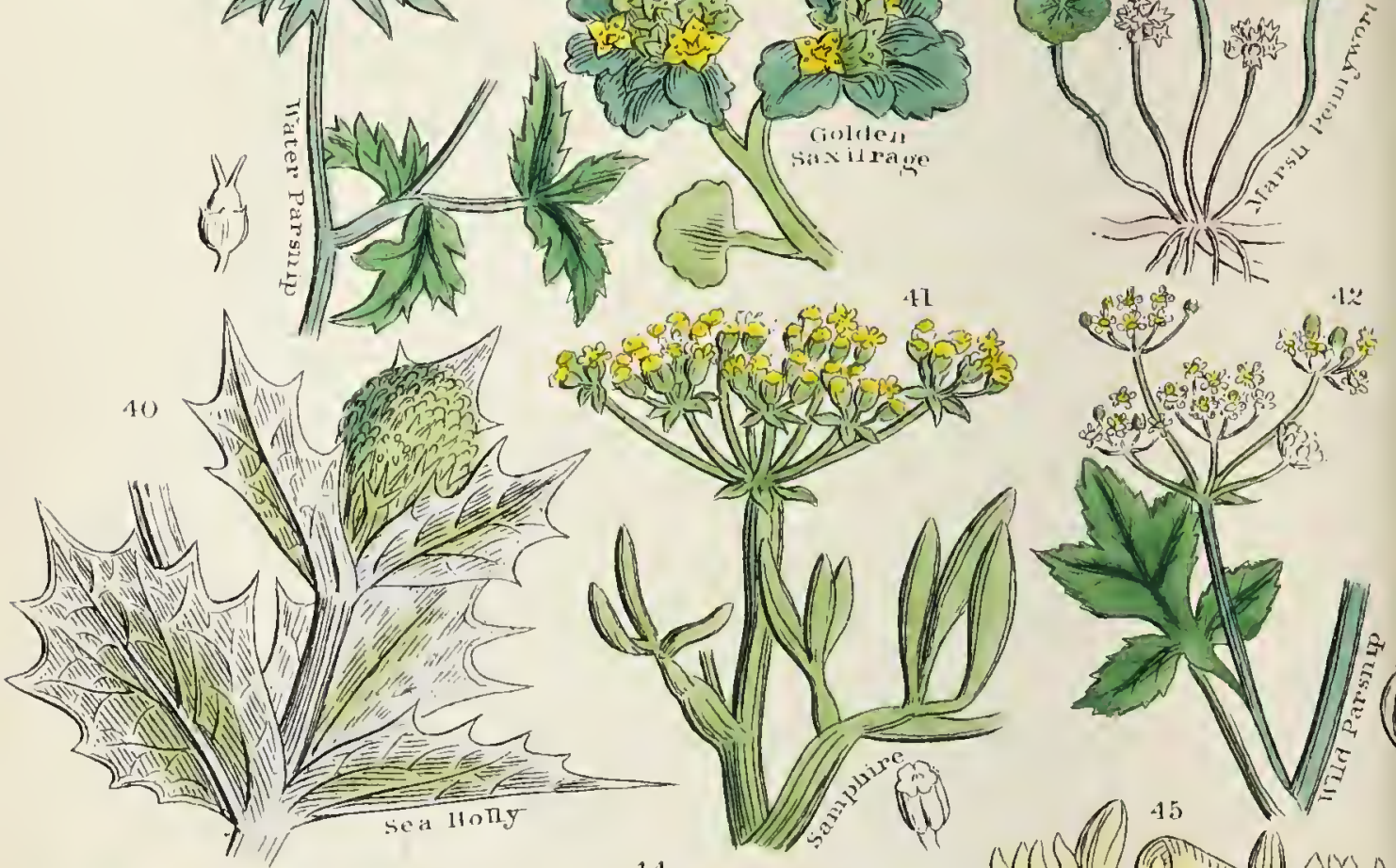

An

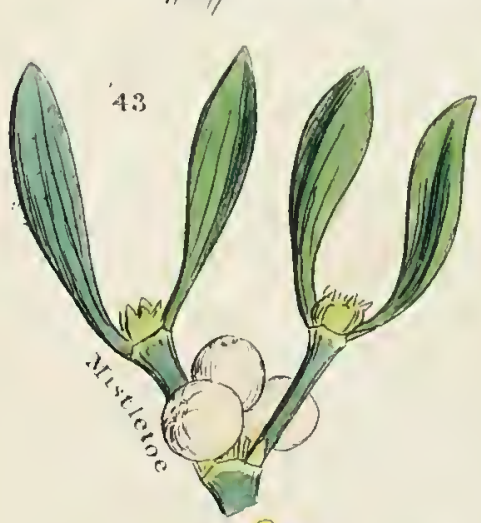

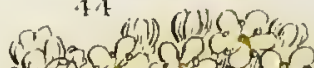

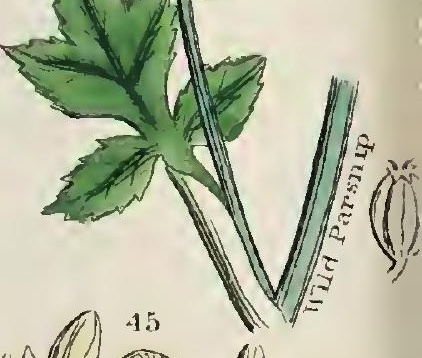

sol

os

(n)
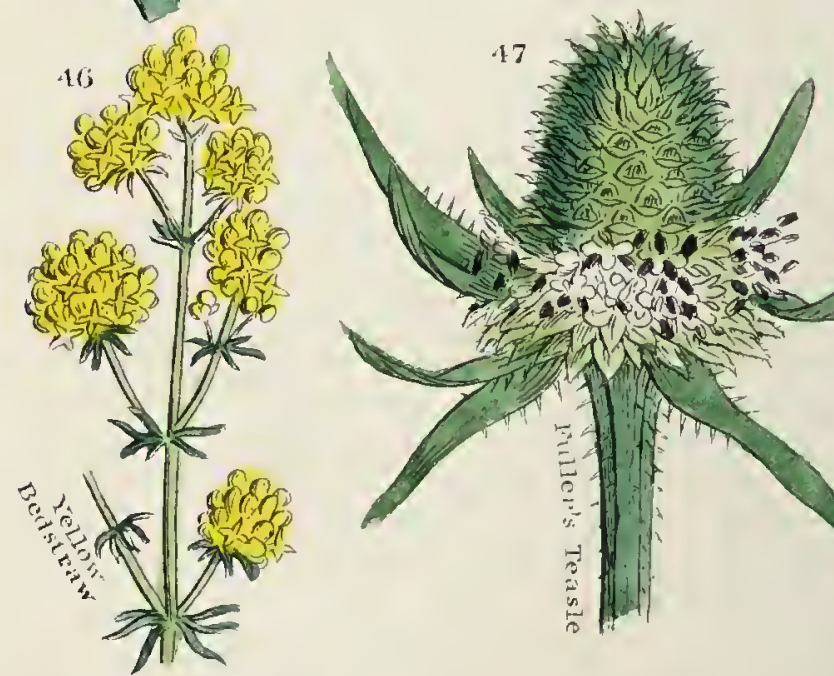

Q(1)

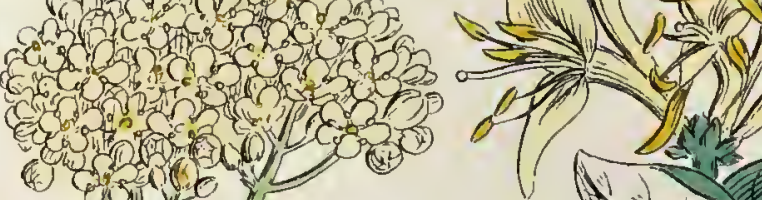
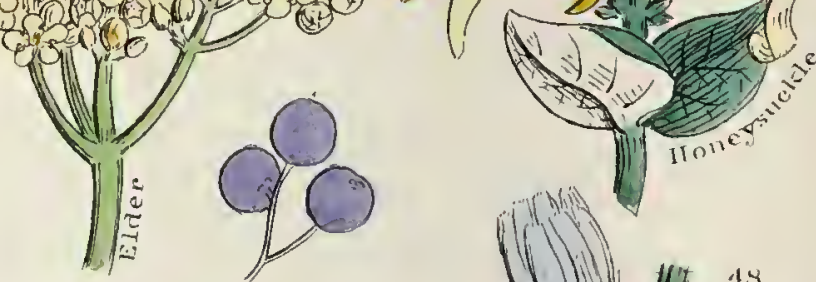
The stem has a purplish hue, and bears but one rather large yellow flower with red dots. The leaves are alternate, narrow, oblong or linear, and entire. This is one of the rare plants which it is so interesting to find. It inlabits wet, turfy moors, at high elevations, and has not yet been supposed to extend further north than Berwick. It is worth cultivation, and will grow well in peaty bog earth. The saxifrages of Great Britain include the London Pride, that pretty well-known flower of the gardens, which is the $S$. umbrosa.

The S.oppositifolia, or Purple Saxifrage, is a favourite spring plant, which, though found growing in wild luxuriance on the Welsh and Highland mountains, is eagerly songht for and sold in Covent Garden Market as an early spring flower. There are many other British species. Mr. Bentham describes thirteen. Medicinal properties have been attributed to some of them, and the white flowers of the common saxifrage were supposed to indicate that it was "groverued by the moon."

\section{THE WATER PARSNIP.}

(Fig. 37.)

\section{SIUM ANGUSTIFOLIUM.}

The narrow-leaved Water Parsnip is a plant belonging to the family Umbelliferæ. It has an erect stem, branched and leafy. The leaves pinnate, the leaflets unequally lobed and serrated; the umbels or 
branch of flowerets, opposite the leaves. It is found in wet ditches and shallow streams, and being of a poisonous nature, ought to be carefully distinguished from the water-cress, with which it often grows. Another species, S. nodiflorum, is, however, more frequently mistaken, and is therefore called Fool's Water'cress.

\section{THE GOLDEN SAXIFRAGE.}

(Fig. 38.)

\section{CIIRYSOPLENIUM ALTERNIFOLIUM.}

Turs plant belongs to the order Saxifragacer, but is not certainly a true Saxifrage. The habit of thus giving common English names to plants of different genera leads to much confusion. It has alternate leaves, the lower ones kidney-shaped, hairy, and seated on long stalks. The flowers are small, in little branches surrounded by leaves, and of a deep-yellow colour. It is not a common plant in Great Britain, although pretty generally distributed. It flowers in the spring by the sides of rivulets, and in moist shaidy places.

\section{MIARSH PENNYWORT.}

(Eig. 39.)

\section{IIYDROCOTYLE VULGARIS.}

Aiv UyBellferous plant, having a slender peronnial stem, creeping along the wet mud, or even 
floating in water ; rooting at every joint, and sending out from the same point small tufts of leaves and flowers. The leaves are orbicular, one to one inch and a half in diameter, smooth, and attached by the centre to rather a long stalk. The flowers are very small, white, and on short stalks. The shape and size of these leaves somewhat resemble a piece of money; hence the name pennywort. It is also known as Pennygrass, White-rot, Fluke-wort, and Sheep's-bane. These latter names it has obtained on account of its being supposed to produce the rot and other diseases in animals that feed upon it. This is, however, an error, as it does not produce disease, but occurs in damp, moist situations, where animals that feed are likely to be attacked with rot and other diseases.

\section{\$EA HOLLY.}

(Fig. 40.)

\section{ERYNGIUM MARITIMUM.}

I AM glad to write again of a sea-shore plant, for I associate with them quiet bright holiday hour's; the never-weary sea, rippling on the clean smooth beach ; happy children with spades and willing hands, making fairy gardens in the sand, filled with the wild fiowers which grow around and up the sides of the cliffs, whither they climb, regardless of downfalls, to secure their treasures; but woe to the little hands that recklessly seize in their grasp the treacherous Sea Holly, with its stiff, sharp-pointed, prickly leaves. 
They are covered with a bluish or sea-green bloom, being what is called in botany, glaucous. This character is very common in plants growing near the sea, but not confined to them. 'One would not easily recognize the Eryngium as an Umbelliferous plant; but if it is carefully examined, it will be found to preserve all the characteristics of the order. The upper leaves embrace the stem, which is about a foot high, and are lobed and palmate in shape. The flowers are in heads rather than umbels, of a pale-blue colonr. It is very abundant on the eastern shores of England, and is found in Scotland and Ireland. The plant is often called Sea Eryngo, Sea Hulver, and Sea Holme. According to Linnæus, the flower-shoots are very good when boiled and eaten like asparagus. The leaves are sweetish, with a warm aromatic flavour. The root also is sweet to the taste, and has a warm, aromatic smell. It has been used in medicine, and was recommended by Boerhaave, the great Danish physician. It is candied and sold in the shops in London as a sweetmeat. At Colchester, in Essex, there exists an establishment where this preparation was first made, more than two centuries ago, by Robert Buxton, an apothecary. There is also another British species, E. campestre, called by John Ray, Friar's Goose.

\section{THE SAMPHIRE.}

(Fig. 41.)

\section{CRITHMUM MARITIMUM.}

The Samphine is also an Umbelliferous planto Thuse who have once seen it and smelt it will recog- 
nize it again. It grows in places where none but the adventurous can reach, - on the sides of cliffs, near the sea, and in the clefts of rocks ; it fringes the edgres of precipices with its bright-green succulent leaves and tiny blossoms. It is almost woody at the base ; the young branches, foliage, and umbels, thick and fleshy. The leaves are twice or thrice ternate, with thick linear segments about an inch long. The flowers are greenish, or yellowish-white, in umbels of fifteen to twenty or more rays. The samphire is warm and aromatic in flavour, and is frequently used as a pickle. Visitors to the sea-side who wish to try this pleasant condiment, cannot do better than look for it on the sides of the cliffs, and, if within reach, gather a basket-ful of its bright-green leaves; they should be separated from the stalks and flowers, and then have spice and boiled vinegar poured on them in the usual way. Samphire-gathering, when pursued as a trade, frequently leads to loss of life, and terrib]e dangers are encountered to secure it. It has almost a classical association, since Shakspeare immortalized it in "King Lear." It grows well on chalk rocks, such as form the cliffs at Dover; there, Edgar is supposed to be leading Gloucester along, and says,-

"Come on, sir ; here's the place : stand still. How fearful And dizzy 'tis, to cast one's eyes so low!

The crows and choughs, that wing the midway air, Show scarce so gross as beetles. Halfway down Hangs one that gathers samphire; dreadful trade! Methinks he seems no bigger than his head: The fishermen that walk upon the beach Appear like mice." 
It abounds also in the Isle of Wight, and many other sea-coasts of England, especially in the South, where, with its bright green colour, it gives quite a character to the clifs and caves which overhang the sea.

\section{WILD PARSNIP.}

(Fig. 42.)

\section{PASTINACA SATIVA.}

The Wild Parsnip is very common on banks and in hedges when the soil is of chalk. It also belongs to the family Umbelliferæ. It has an angular, furrowed stem; pinnate leaves, more or less downy, especially underneath, with five, seven, or nine segments, each one to three inches long, sharply toothed and more or less lobed. The flowers are yellow, in umbels, not very large, of eight to twelve rays. The root is spindle-shaped, and has the same appearance, odour, and taste as our well-known vegetable, which is, indeed, but a cultivated variety of the wild kind. In its native state, the root is tough and woody. It blooms during July and August, and its yellowish-green seeds remain on the stem until November. These contain an essential oil which once had a reputation as a cure for intermittent fever Hogs are fond of the roots, and quickly fatten on them. Parsnips have erroneously been supposed to contain a large quantity of nutritious matter. They are not so good for food as many other vegetables. 
In the north of Ireland a kind of beer has been brewed from the roots, flavoured with hops; and the root yields by distillation an ardent spirit, from which a respectable sort of wine is made. In the colour of the flowers it is an exception to most of its family, as but few of the umbelliferous plants have any but white flowers.

\section{MISLETOE. \\ (Fig. 43.) \\ $V I S C U I I$ ALBUDT.}

Our next plant is associated with thoughts of pleasant meetings and festive boards, and happy are those whose homes are filled at Christmas time with the cheerful companions of summer rambles, having health and spirits to enjoy the good gifts of God in any form. The Misletoe, or Viscum allum, is one of a genus of parasitical plants belonging to the family Loranthaceæ, and is the ouly British representative of the family.

"Misletoe," says Lord Bacon, "chiefly grows on crab-trees, apple-trees, sometimes upon hazels, and rarely upon oaks, the misletoe whereof is accounted very medicinal. It is an evergreen that bears a white glittering berry, and differs entirely from the tree whereon it grows. It continues green winter and summer, which the tree does not."

"Nought was green upon the oak, But moss and rarest misletoe." 
In many respects the Misletoe is an object of great interest to the naturalist. The manner in which it derives its nourishment from other plants by engrafting itself into the branches of a tree, and the curious conditions of the seeds in germination, are worthy of attention.

I need scarcely describe the plant so familiar to us all, as there is little fear of its being mistaken for any other. I may, however, say that the leaves are entire, varying from narrow oblong to nearly oval-thick, fleshy, and always obtuse. There are two kinds of flowers, those bearing pistils and those bearing stamens, each on separate plants : they are very small, and are placed in little heads, about three to five in each. The berry is about the size and has somewhat the appearance of a white currant, very smooth, viscid, and containing a simple seed. The manner in which the plant establishes itself in the branch of a tree has been much discussed. Old botanists believed that the "Misletoe Thrush" feeding upon the berries surrounded his beak with the viscid mucus they contain, and in order to get rid of it, rubbed his beak against the branches, and thus inserted the seeds, from which springs a new plant. Paley, in his "Natural Theology," gives at length his views on the subject. Of no other plant can it be said that the roots refuse to shoot in the ground, and no other plant is known to possess this adhesive generative quality when rubbed on the branches of trees.

The seeds in germination seem to offer an exception to the general law-that the radicle or root of the embryo shoots downwards, and the plumule upwards; 
for it is found that the radicle of the Misletoe invariably turns itself down upon the body to which it is attached, whatever may be the position of the surface of that body with respect to the earth. For instance. if a cannon-ball to which misletoe seeds are glued on all sides be suspended by a cord some distance from the earth, both the upper and under seeds, as well as those on the sides, all direct their radicle to the surface of the ball. This property insures their growing mpon the branches of trees, to whatever side they may happen to adhere.

It is asserted that a branch of Misletoe, when placed in water, has no power of absorbing this fluid, but that when the branch to which it is attached is immersed, then the water is readily absorbed and penetrates into the Misletoe itself. The following experiment was performed by De Candolle. He immersed the branch of an apple-tree bearing Misletoe in water previously coloured with cochineal, which penetrating the wood and inner bark of the apple-tree, entered the Misletoe, when its colour was even more intense than in the former.

Having no immediate connection with the earth, this curious plant, when discovered on the oak, already a sacred tree, became an object of superstitious worship to the priests of the Ancient Britons. The Druids, as they were called, held it in the greatest reneration, and the ceremony of separating the Misletoe from the oak was one of their greatest religious rites. It was held on the sixth day of the moon, from which day they computed time. The occasion was celebrated by the sacrifice of two 
white bulls, which were tied to the oak-tree by their horns; then one of the Druids, clothed in white, mounted the tree, and with a knife of gold cut the Misletoe, which was received in a "white sagum," or cloth made of wool : this done, they proceeded to their sacrifices and feastings. Our own natioual practice of decoriting our churches and houses with misletoe and holly at Christmas time may, perhaps, be a remnant of the old superstition. If, however, it only be regarded as a pleasant custom, there can be no harm in it, and long may it be ere so graceful a decoration be discontinued. Sir Walter Scott, in describing Christmas in the olden times, says-

"The hall was dress'd with holly green, Forth to the wood did merry men go, To gather in the misletoe."

The origin of the old-fashioned tradition, that a kiss under the Misletoe is only fair play, I am unable to find. I observe, however, as civilization advances, and manners become more polite, this practice is more honoured in the breach than the observance. In a pretty book I have had by me for many years, called "A Wreath of Friendship"," written in part by the late Rev. Professor Henslow, when a young man, are some pretty lines on the Misletoe. I cannot help quoting them here:-

"Past is the time, when bending low, Druids revered thee, misletoe; Error's broad shades are chased away By Revelation's brilliant ray, And superstition can no more Bid us a humble plant adore. 
Yet who in hour of Christmas mirtl, Can place thee o'er the social hearth, With ivy and with holly gay,

Or twine thee with the fragrant bay,

Nor lift with joy his heart above,

Nor hymn the notes of praise and love?

Fair plant, a mystery thy birth,

Thou dost not fix thy home on earth ;

Rock'd by the winds, fed by the shower,

Thy cradle is an airy bower ;

No voice of crime in thy leafy dome,

But the songs of birds to cheer thine home.

From the wilding crab this branch was riven, From waving in the breath of heaven.

Alas! alas! they have brought it low,

To the dwellings of care, and pain, and woe."

\section{EL D ER.}

(Fig. 44.)

\section{$S A M B U C U S \quad N I G R A$.}

The Common ol Buach Elder, is a small tree or large bush, belonging to the family Caprifoliaceæ. It is known by possessing a five-cleft calyx, a five-cleft rotate corolla, five stamens, and three stigmas, a roundish pulpy one-celled berry, hardly crowned by the remains of the calyx. The stem is irregularly but always oppositely branched, the young branches are elothed with a smooth grey bark, and filled with a light spongy pith; the leaflets are deep-green and smooth, usually with an odd one. The flowers are in bunches of a cream-colour, with a sweetish but faint smell. The berries are black, with reddish stalks. 
Considerable medicinal value was at one time attributed to this plant, but it is now chicfly used in the rural districts of England for making a wine from the herries, which, when spiced and drunk hot, is regarded by some people as very agreeable. The flowers are employed in making a distilled water, which is cooling and refreshing, and is sometimes introduced into confectionery. The wood is hard and tough. The pith, on account of its solidity and great lightness, is used for making small figures and balls for electrical experiments. The undeveloped buds when pickled, form a good substitute for capers. It is on the leaves of the elder that the caterpillar of the sphinx or death's-head moth delights to feed. It changes into a chrysalis about September, and in the following July may be seen as the gigantic and curious moth, with the markings of a skull on its thorax. There are two species of elder native in Britain, of which $S$. Ebulus, or Dwarf Elder, a rare plant, is the other.

\section{HONEYSUCKLE, OR WOODBINE.}

(Fig. 45.)

\section{LONICERA PERICLYMENUM.}

This is a favourite flower, on account of its delicious fragrance and its lovely blossoms, intermingling with every hedge-row, and turning round the trunk of many a sturdy tree. It belongs to the family Caprifoliaceæ. The leaves are ovate or oblong, smooth 
above, somewhat downy or slightly hairy beneath,-the upper ones the smallest. The flowers are of a pale-yellow colour, the corolla about an inch and a half long. The berries are small and red. There are two other species of honeysuckle native in Britain,L. caprifolium, the Perfoliate Honeysuckle, or Goat'sleaf, and L. Xylosterm, the Fly or Upright Honeysuckle.

The leaves of the perfoliate honeysuckle are quite smooth and broader than those of our example, and it flowers earlier in the year. The fly honeysuckle is rather rare; it has white scentless flowers, and is by no means so attractive as either of the others. It is often planted in shrubberies.

The true Woodbine of the poets is undoubtedly the L. Periclymenum; it obtains the name evidently from a corruption of woodbind, from its habit of twisting round the stems of trees. Milton calls it "the Twisted Eglantine," and Shakspeare says-

"So doth the woodbine, the sweet honeysuckle, Gently entwist the maple."

At the base of its long tubular flower lies the honey, and when the bee cannot reach it, other insects tap it, by making a puncture at the base of the tube, and thus regale themselves. In almost every country lane in England, from early in June to August, are we delighted with the sweet scent of one or other of these pretty climbers; and well do I remember, on a memorable occasion, becoming almost overpowered with the perfume, as bough after bough was pulled from its native Suffolk hedge, and piled up, so as to 
make a floral enuch in a carriage in which $I$ sat one still warm summer evening in July. Later in the year, the clusters of bright red berries, which follow the flowers, are very picturesque, and afford food for the birds; for they are not poisonous. The hawkmoth is often found hovering near the honeysuckle, attracted, perhaps, by its fragrance or feeding on the honey it contains.

\section{YELLOW BEDSTRA W.}

(Fig. 46.)

\section{GALIUM VERUM.}

Ladies' Bedstraw, or Cheese Rennet, belongs to the family Rubiacea. It is distinguished by having its leaves about eight in a whorl, small, and linear, The stems are much branched at the base, six inches to a foot long, ending in a panicle of small golden-coloured flowers. The roots afford a rich yellow dye, and impart this colour to the bones of animals who feed upon it. The whole genus possesses a property like that of rennet, of curdling milk, which gives rise to their common name. The Galium verum is one of the prettiest plants, which decorates our driest sand-banks, gaily blossoming for full three quarters of the year. It is the sweetest of all the genus, and was formerly much used for strewing floors and laying in beds; whence the name of bedstraw, at a time when feather-beds and luxurious spring couches were unknown. According to John Ray, the flowering tops, when distilled, make a refreshing beverage, 
and the roots are useful as an astringent medicine. The French used formerly to prescribe the flower's in hysteria and epilepsy.

\section{FULLER'S TFAZLE.}

(Fig. 47.)

\section{DIPSACUS FULLONUM.}

The Fuller's Teazle will be easily recognized, from the drawing, although we have one or two other British species. It belongs to the family Dipsacer, and is a stout biennial, four or five feet high, with numerous prickles on the stems, the leaves, and, in fact, on the whole of its surface. The heads of the flowers are of a pale lilac-colcur, at first ovoid, but gradually becoming cylindrical, nearly three inches long and about one inch and a half in diameter; the scales of the involucre are hooked, or reflexed, and very hard. On this account they are used in the manufacture of cloth in a process of brushing or raising, called teazling. It consists in applying the ripened head or fruit of the teazle to the cloth. The teazles are attached to a cylinder, which revolves upon the cloth, and the loose particles are raised, so that they may be easily sheared or cut off, to give the cloth the fine appearance it assumes. No instrument has ever been invented to supersede the teazle. Various substitutes have been tried; pieces of wire have been fixed into a leather back, but nothing answers the purpose so well as the elastic spines of the teazle.*

- See Dr. Lankester's Lectures on the Uses of Animals. 
The plant is imported in large quantities from France and other parts of Europe, and is also extensively grown in Eugland; but as a hot sun and dry weather are essential to the proper drying of the teazle heads, those imported from the Continent are esteemed the best. Country people are still said to cure agues in various parts of England by a singular remedy obtained from this plant, which is of course only imaginary. If the heads be opened longitudinally in the autumn, a small worm may frequently be foumd in the centre. Of these, three, five or seven, always an odd number, must be taken, sealed up in a quill and worn in good faith, as an amulet or charm against ague.

\section{CH I C O R.}

(Fig. 48.)

\section{CICIIORIUM INTYBUS.}

Chicory, or Succory, belongs to the family Compositæ. It is often seen growing wild on the borders of our corn-fields, and is sure to attract attention by its pretty blue flowers. It is from one to three feet high. The leaves near the ground are spreading, more or less hairy, with a large terminal lobe and several smaller ones, all pointed and coarsely toothed, the upper leaves smaller, less cut, and embracing the stem by pointed auricles. The flowers are in heads, in closely sessile or unstalked clusters, of a bright blue colour. When blanched, or grown without light, the 


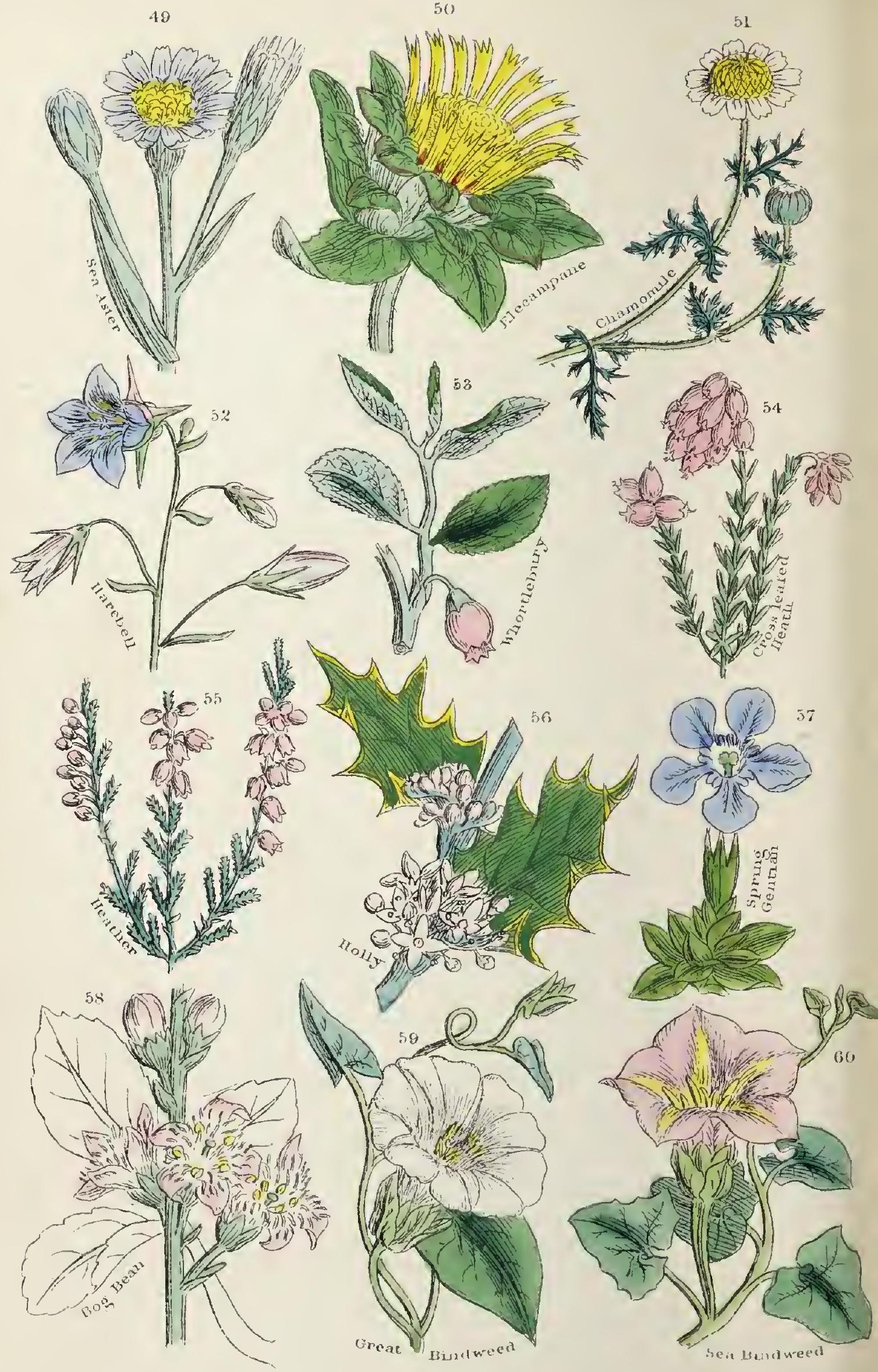


leaves are often eaten in early spring salads, and are very good ; they are somewhat bitter, like endive, but lose that taste by cultivation. The French call the long slender leaves "Barbe de Capuçin," Monk's Beard. The root is long, like a carrot, and is used in large quantities, when dried, as a substitute for, or an addition to, coffee. In Belgium and many parts of Germany, large districts are devoted to the cultivation of this plant for the sake of its root, which is dried in a kiln or slow oven. It is afterwards roasted like coffee, ground in a mill, and sold in the market. It is decidedly a pleasant addition to coffee ; but, being much cheaper than the coffee berry, it becomes an adulteration when mixed with it and sold as pure coffee. If a teaspoonful of the powdered chicory be added to a teacupful of ground coffee, it will be found to improve the flavour, and to be in no way injurious.

\section{THE SEA ASTER.}

(Fig. 49.)

\section{ASTER TRIPOLIUM.}

The Sea Aster, or Sea Starwort, is a pretty plant, found growing in salt marshes, near the coast, and belonging to the family Compositx. It is seldom above a foot high, erect or decumbent at the base; slightly branched, the leaves linear, entire, and somewhat succulent. The flower-heads are in a compact corymb; the involucral bracts few and oblong. The centre of the disk of the flower is bright-yellow, the circumference blue or purple. 


\section{ELECAMPANE.}

(Fig. 50.)

\section{INULA HELENIUM.}

Elechapane is found in pastures in various parts of Europe. It is a native of Great Britain, and belongs to the order Compositæ. It has a thick, branching root, which is aromatic, bitter, and mucilaginous. The stem is three feet high, leafy, round, furrowed, solid branched, and most downy in the upper part. The leaves are large, ovate, serrated, and veiny, downy and hoary at the back; the root-leaves stalked; the rest are sessile, clasping the stem. The flowerheads are solitary, at the downy summits of the branches, two inches broad, of a bright-yellow colour, with reddish strealss; the scales of the involucre are broad, recurved, leafy, finely downy on both sides. The rays are very numerous, long, and narrow, each ending in three unequal teeth. Various preparations of the boiled root have been recommended, mixed with sugar, to promote expectoration and to strengthen the stomach. Some think a spirituous extract contains most of its aromatic and tonic properties. We may generally find the plant in cottage gardens, on account of its reputed virtues. Inulin, a peculiar substance contained in the root, is a form of starch insoluble in cold water, but soluble in hot water, from which it is deposited on cooling. With iodine it gives a greenish-yellow compound which is not permanent. 
Inulin is distinguished from gum by its insolubility in cold water, and is otherwise chemically interesting.

\section{CHAMOMILE.}

(Fig. 51.)

\section{A NTIIEMIS NOBILIS.}

Common Camonule, ol Chamomile, is frequently found in a wild state on many of the commons near London, where it adds a peculiar richness of colour and fragrance to the turf. It is a dwarf plant, belonging to the family Compositæ, with finely-cut leaves; the flower-heads are white in the ray, but deep-yellow in the disk. All parts of the plant are intensely bitter, especially the little yellow flowers of the disk; for this reason the wild flowers are more efficacious than the cultivated sort, in which there is scarcely any disk, the white flowers of the ray having almost entirely usurped their place. An infusion or extract of these flowers is often used in medicine as a stomachic, and also as a fomentation externally. Besides the bitter principle contained in this plant, chenists have obtained from it camphor and tannin, and also a volatile oil, of a beautiful blue colour.

\section{H A R EBELL.}

(Fig. 52.)

\section{CAMPANULA ROTUNDIFOLIA.}

No wild flower is more admired, or has had its praises sung by poets more frequently, than this pretty 
delicate little inhabitant of every heath and sunny bank of our comutry districts. Every village child loves its pretty bells, and numberless are the fancies which connect it with fairy legends and floral charms. It seems scarcely necessary to describe it botanically; but, lest it should be confounded with other species of the same genus, it may be well to say that it belongs to the family Campanulacer. The leaves on the tiny stem are very slender, like those of grass, but near the ground there are a number of roundish notched leaves, which mostly die away at the time of flowering. The bell-shaped corolla is of a pale blue colour, and has five broad lobes, much shorter than the entire fruit. We have nine wild species of Campanula, some of which have stout stems with Iarge purple flowers, many of which bear the cultivation of the garden very much better than our true little Harebell, which is mhappy away from its native haunts. The Canterbury Bell, with its large handsome flowers, is one of the favourites of our gardens, and at one time abounded in the neighbourhood of Canterbury and other parts of Kent: it was gathered by pilgrims to the shrine of St. Thomas à Becket there, and treasured in evidence of the task they had completed. The little plant I have chosen as most worth notice is the true Harebell of Scotland, the same which in the "Lady of the Lake" is mentioned as being strewn in Ellen's pathway.

"For me she stoop'd, and looking round, Pluck'd a blue harebell from the ground; This little flower that loves the lea May well my simple emblem be." 
It is said that the presence of the Harebell indicates a barren soil; yet how lovely are its tiny cups on their cobweb stems, gently waving to and fro with every breath of wind, so that one might almost believe in the reality of the silver music said to come from them in the days of yore, when the good fairies

"Rang their wildering chimes to vagrant butterflies."

And even now, with all the sobering influences of botanical study upon us, we can heartily sympathize with the little one who, having filled her lap and hoth hands with blue bells inuumerable, and white bells, too, both growing close together, was heard to whisper in the real spirit of prayer and happiness "Dear God, do make some jink bells too!"

\section{BLACK WHORTLEERRY.}

(Fig. 53.)

\section{VACCINIUM AYYTILLUS.}

Tins plant, known also as Black Whortleberry, may be regarded as the representative of the British berries known as Bilberries, Cranberries, Cowberries. Windberries, \&c. It belongs to the natural order or family Ericaceæ, and is a small shrub, from six inches to a font high, with spreading green branches. The leaves fall off in the winter, and are small, ovate, with tiny teeth, and a very small stalk. The flowers are nearly round, of a pale greenish white colour, with a tinge of red, growing singly in the axils 
of the leaves. The berries are round, nearly black, and covered with a bluish kind of bloom, crowned by the short teeth of the calyx. This shrub is found on most mountain heaths and woods throughout England, Scotland, and Ireland, with the exception of the eastern part of Ingland. The leaves have been much used in the adulteration of tea. The berries are frequently eaten, either in tarts or uncooked. They have a sharp astringent flavour, which is not pleasant to every one, but, like the rest of the family, they have their admirers.

The Cranberry, $V$. Oxycoccus, is well known, and is much liked in England. Great quantities of the berries are imported from Russia, Sweden, and America, into this country, packed in tubs. They are considerably larger and finer in appearance than those grown in our own country, but not so full of flavour.

The other species of Vaccinium are the Bog Whortleberry, V. uliginosum, and the Red WhortleLerry or Cowberry, V. Vitis-idac.

\section{H E A T H.}

(Fig. 54.)

\section{ERICA TETRALIX.}

Trins is the most widely distributed and best known of all our native heaths. The leaves are four in a whorl, lanceolate and linear, ciliate, downy above and on the midrib beneath. The stem is bushy at the base, with rather short, erect, flowering branches. 
The flowers are rose-coloured, forming little clusters or close umbels at the end of the stalks. It is commonly found in the West of Europe, and in Britain is most plentiful in the western counties. I have, however, constantly found it in Suffolk, the Isle of Wight, and other parts, often growing with the heather or Calluna vulgaris, from which it is well to distinguish it. The larger and more bell-like blossoms of the Erica, and its downy appearance, are the evident marks by which we may recognize it. These heath flowers were adopted as the the badges of the Highland clans; and although this heath is not especially a Scotch plant, the Erica tetralix was borne by the Macdonalds, the Erica cinerea by the Macalisters, and the Calluna vulgaris by the Macdonnells. All these plants grow together on the moors and fells in the North of England and Scotland, and give a peculiar aspect to the landscape, shedding as it were a purple hue over the distant mountains, and forming a characteristic feature of these northern districts.

There are six species of Erica in Great Dritain.

\section{HEATHER。 \\ (Fig. 55.) \\ CALIUNA VULGARIS.}

The Heather grows, as I have said, in common with the heaths, and is often mistaken for them. Its smaller more purple blossoms, placed all along the stems in little bunches, will serve to distinguish it. 
Sometimes the flowers are white, but this is rare. It is especially the plant of the Highlander, and is associated so strongly with his country in all its legends and poetry, that it appears almost as exclusively the child of the mountain fastnesses as the national music of the bagpipe. To the Highlander this plant is something more than a mere badge of clanship; it furnishes lim with much that is valuable in everyday life. The heather branches, freshly gathered and arranged so that the elastic tips of the shoots form a level surface, constitute a couch such as that described by Sir Walter Scott :-

"Before the heath had lost the dew, This morn a couch was pull'd for you, On yonder mountain's purple head."

And again,-

"The stranger's bed

Was there of mountain heather spread."

Cabins are also thatched with it, and the walls of the cottages are often made of alternate layers of heather and a kind of mortar. As fuel it serves well, and it is said to yield a yellow dye, which I am told is at present used by the cloth-manufacturers of Yorkshire. Moreover, in England the sprigs of the heather are constantly made into brooms or besoms, which are very serviceable. As food for moor game and grouse, the heather is almost essential, and it is only where this plant will grow that these birds can be preserved. The red deer also crops the young shoots of the heather. Bees extract honey from the flowers, which, though dark in colour, is very rich in flavour. 
I have seen the heather, and, indeed, many species of lieath, prettily used as a border for flowerbeds in gardens. Sir W. Hooker suggested it, and has carried it out at Kew. Accustomed as we are in the southern districts to see the heath plants only as a low shrub, a foot or two in height, we are surprised to read of-

"ITeather black that waved so high, It held the copse in rivalry."

Yet so it is, and in certain wild and peaty districts it may be found quite tall enough to justify this description.

\section{THE HOLLY.}

(Fig. 56.)

\section{ILEX AQUIFOLIUM.}

THis plant belongs to the small natural family Aquifoliaceæ, and is the only British representative of the tamily. It seems hardly needful to describe so well-known and favourite a tree, associated as it is with the happiest days of childhood, with Christmasday gatherings and merry-makings, with joyous faces and warm hearts, while to some of us, perhaps, who have passed the sunshine of life, its bright green leaves and red berries may call up memories of the companions of past years, now passed away, never more to share in our joys or our sorrows. Familiar as we all are with the red berries of the Holly, we may not have seen its flowers, for they blossom when 
all nature is bright, and are overlooked amidst their more showy and attractive neighbours. They grow closely round the stem, and are white and wax-like, opening in May and June. The bright shining green leaves are armed with sharp prickly teeth, but the upper ones on a bush are frequently smooth. This circumstance the poet Southey impresses on the memory in his charming lines on the Holly Tree,-

"Polnw a circling fence its leaves are seen,

Wrinkled and keen.

No grazing cattle through their prickly round

Can reach to wound;

But as they grow where nothing is to fear, Smooth and unarm'd the pointless leaves appear."

The tendency to produce these prickly points renders the Holly peculiarly fit for hedges, and when Dutch horticulture prevailed in England, such hedges were not unfrequent.

"A hedge of holly, thieves that would invade, Fiepulses like a growing palisade."

The celebrated John Evelyn had such a hedge at Say's Court, four hundred feet long, nine feet high, and five feet broad, which he planted at the suggestion of Peter the Great, who resided at his house while he worked in the Deptford Dockyard. In his Diary he asks, "Is there under heaven a more glorious and refreshing sight of the kind than such an impregnable hedge, glittering with its armed and varnished leaves, the taller standards at orderly distances blushing with their natural coral?" The Holly is a very slow-growing tree, and its timber is 
amongst the hardest of white woods; it is much used by turners, and especially in the manufacture of 'lunbridge ware.

\section{THE SPRING GENTIAN.}

\section{(Fig. 5\%.) \\ GENTIANA VERNA.}

Tris is one of the brightest ornaments of our northern districts. It belongs to the family Gentianacex, and to a genus which flomrishes especially in Alpine and Arctic regions. This pretty little Gentian is, however, sometimes found in warm mild districts. I have met with it in the Isle of Wight, on Shanklin Downs. Bitterness is a characteristic of the whole family, and this principle seems to have something to do with the bright blue colour of the blossoms, for the brighter the hue the more bitter the taste. Our little spring Gentian has a perennial leafy stock, rensely tufted, often spreading to four or five inches in diameter, with ovate or oblong leaves. The flowerstems are simple and numerous, sometimes so short as to give the flowers the appearance of being seated on the leaves; sometimes they are an inch or two in length, and bearing one bright-blue terminal flower. The corolla is tube-like, nearly an inch long, with five ovate lobes, and smaller two-cleft ones between them. The bitter principle of all the gentians is valuable as a medicinal agent. 
G. nivalis, the little Snow Gentian, grows on our loftiest mountains in Scotland and Wales, but is far hetter buown as a native of the Alps and Pyrenees.

\section{PUCKBEAN, OR MARSH TREFOIL.}

(Fig. 58.)

\section{MENYANTHES TRIFOLIATA.}

Tine Buckbean belongs also to the family of Gentians -Gentianacere. It is a beautiful aquatic herb, and is found in wet bogs and shallow ponds all over Great Britain. The stem is short, creeping, or floating, with a dense tuft of leaves, consisting each of a long stalk, sheathing at the base, and three obovate or oblong leaflets, one to one and a half inches long. The flowers are white, tinged externally with pink, in an oblong raceme on a peduncle of from six inches to a foot long, proceeding from the base of the tuft of leaves. The corolla is deeply five-lobed, and fringed on the inside with white filaments. None of our native plants exceed this in beanty. In the fresh-water aquarinm it is a beautiful object, and may easily be preserved in this artificial condition for some time. In common with all its family, the Marsh Trefoil abounds in an intensely bitter quality, which has frequently been used medicinally. Withering says that the leaves have been used during a scarcity of hops as a substitute for them in brewing beer. 


\section{GREAT BINDWEED.}

(Fig. 59.)

\section{CONVOLVULUS SEPIUM.}

THere can scarcely be any occasion to describe this favourite and well-known plant, which wreathes its graceful festoons over our hedgerows, opening its large tender white blossoms to the bright sunshine, and gathering their folds together as a rain-cloud foretells the approach of a shower, which would shatter their delicate texture. Botanists no longer call this plant by the old name so familiar to our childhood. It is no longer the Convolvulus, but is known as a distinct genus, under the name Calystegia. The lovely white blossoms survive but for a single day; whence they are called "Belle de jour" by the French. They are, however, so rapidly succeeded by a profusion of buds realy to take their places, that the decay is not noticed, and our attention is taken off from the flower which has lived "its little day" and is now no more. A well-known author says, "How affecting an emblem of human life does this simple Convolvulus present to us. The gay, the young, whose existence has seemed but a day, are cut off, and others, equally gay and equally mortal, occupy their places; and the remembrance of them is quickly dissipated by the attractions of their successors, who, perhaps, like them, are doomed early to submit to the common lot of humanity." 
Ceauty alone is not the sole merit of this plant; the root has properties similar to those of $C$. Scammonia, and has been used as its substitute under the names of Montpellier and Bourbon Scammony. It has an ancient reputation as a medicinal agent, Galen himself being said to have recommended the leaves as an external apylication to swellings and abscesses.

\section{SEA BINDWEED.}

(Fig. 60.)

\section{CONVOLVULUS SOLDANELLA.}

TuIs is one of the prettiest of our sea-shore plants. It is abundant on the eastern coasts of England, on sand-hills, and flourishes well on the red clay of Suffolk and Norfolk. It belongs to the same family as the large Convolvulus, but is mucl smaller, trailing along the ground, and seldom rising to a height above six or eight inches. The leaves are small and kidneyshaped, with broad lobes at the base. The flower is of a delicate or bright pink colour, streaked sometimes with a darker shade. This plant shares, in common with the rest of its family, a reputation for curative properties; indeed, but few of our wild plants have not been employed in rustic pharmacy with more or less success; and it is only since the science of chemistry has proved that the active principles of these vegetable productions are the same in many different plants, and can be extracted by chemical processes, that the practice of making infu- 
sions of all sorts of herbs and weeds has been gra dially abandoned for a more convenient method of administering the valuable principles to be found in nature's laboratory in smaller quantities and a less troublesorne form.

\section{VIPER'S BUGLOSS. \\ (Fig. 61.) \\ ECIIIUMVULGARE.}

THis plant is one of the most beautiful of our wildflowers. It belongs to the family Boraginaceæ, and is known by its showy flowers, having an irregular and unequal margin, and a sort of bell-shaped figure. The red or purple spots and hairs are very remarkable. The corolla is at first of a reddish-purple colour, turning afterwards bright-blue; so that there are constantly flowers of both colours to be seen at once. The whole plant is covered with stiff, spreading, almost prickly hairs. The root-leaves are stalked and spreading, but often withered away at the time of flowering. The common name of Viper's Grass originated from a resemblance the ripe seeds are supposed to have to the head of that reptile; and hence arose the idea that it might act as a remedy against the bite of the creature, - an adaptation of the more recent but not less absurd fillacy that "like cures like." The showy blossoms are very attractive to bees, and not even the sharp hairs by which they are guarded are sufficient to deter these little plunderer's 
from their depredations on the sweet store concealed in the flowers. But we must not consider these little creatures as merely selfish seekers of their own gratification; they, in common with the whole of creation, serve great purposes, and carry out the designs of the Great Architect of all, even without their own consciousness of doing so. As the insect flies from Hower to flower, it transports on its delicate legs and wings some portion of the pollen which is to fertilize the next plant which it enters, and produce seed to reproduce the species. Every class of animals seems to assist in this great work of propagation in the vegetable world. Seeds are carried about by birds and deposited, as if by accident, in situations favourable for their growth; and even the giddy buttertly as it alights on each gay flower in the sunshine, is the messenger of a new life to the rapidly-fading beauty of the garden.

\section{FORGET-ME-NOT.}

(Fig. 62.)

\section{MYOSOTIS PALUSTRIS.}

This is so entirely a flower of associations, that it is difficult to unravel anything like a botanical or prosaic description of the plant itself, from the nunerous poetical fancies and legendary tales by which it is surrounded. It belongs to the Borage family,Boraginaceæ, and has small downy, ovate leaves, which are not unaptly coinpared to mouse-ears. Botanists, fiuding that the plants commonly received as Forget- 


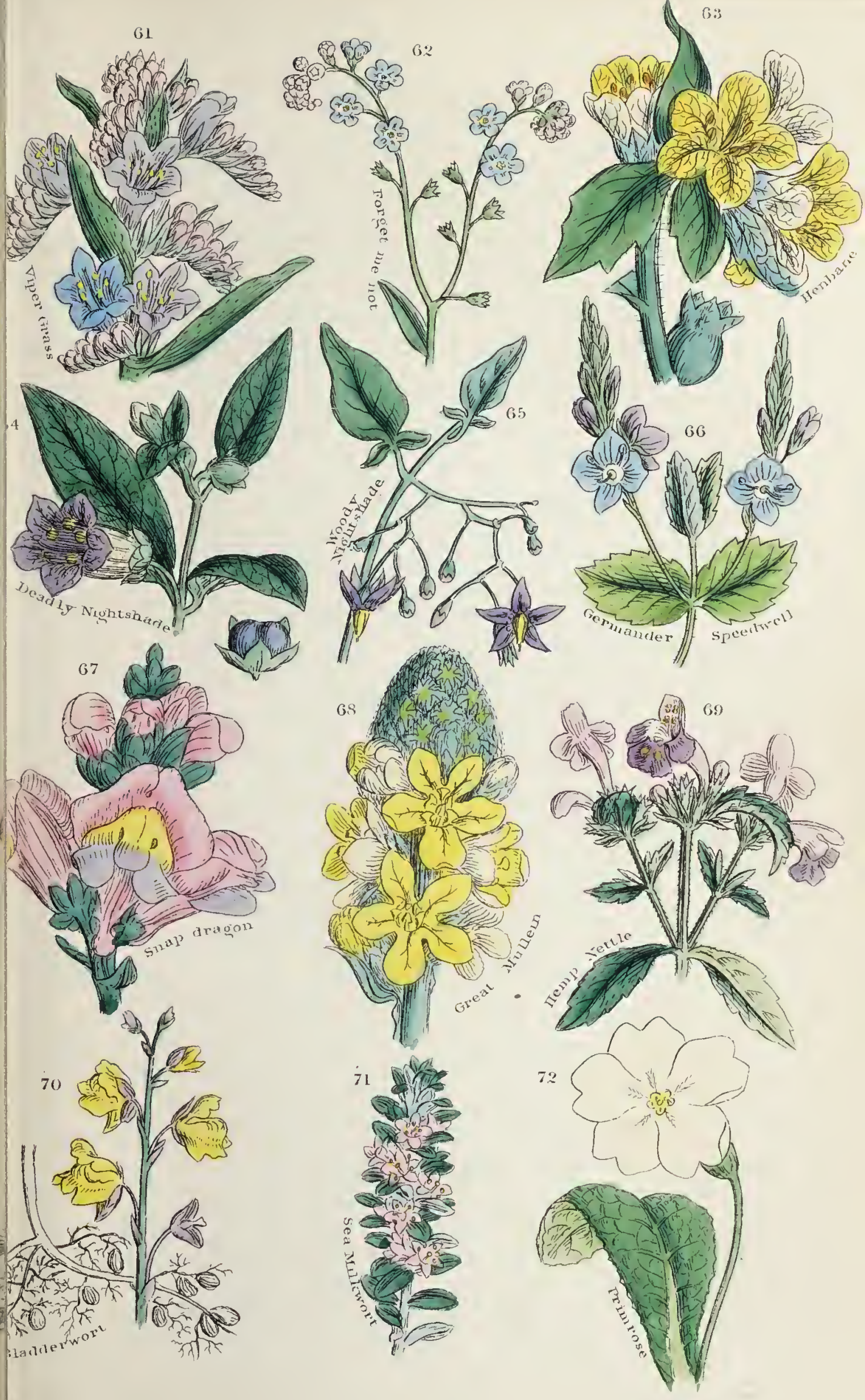



me-nots differ in some minor characteristics, divide the species into three varieties. The true Forget-menot has rather a large rotate flower, of a clear blue colour, with a yellow eye. Most abundantly does it grow beside brooks, rivers, and wayside streams, and - must we say it? - even in stagnant ditches, asking only for moisture to adorn the most deserted places with its turquoise flowers. In cultivation, it will even dispense with this requirement, and will produce blossoms of a larger size than when wild. It is an excellent plant for window gardening, and is improved by "bedding," as the gardeners call it_blossoming all the summer through, if properly trimmed. Beauty, however, is not the sole attraction of this favourite flower; it has associations connected with it in legends, in poetry, and in real life, which live long after its beautiful blossoms have perished. For many centuries it has been regarled throughout Europe as the emblem of eternal friendship or love. It is pleasant to regard so lovely a flower as expressive of a tender feeling. The well-known story is one belonging to the days of chivalry, when a knight and his lady-love were wandering on the banks of a stream where grew clusters of these gem-like flowers. In those days the wish of a loved one was law to the lord: the lady, desiring to possess some of the bright blue blossoms, caused her faithful knight to rush into the stream to obtain them for her, when, overborne by the strength of the current, he was carried away, and could but cast, with dying hand, the flowers she wished for towards her, exclaiming "Forget me not." Even in our less chivalrous and more prosaic times, the language of this 
flower is not forgotten, and it is not long since we saw, on St. Valentine's day, when such sentiments are in fashion, and all nature is pressed into love's service, a pretty painted wreath of "Forget-me-nots" inclosed in a suitable envelope, with the words "Pretty flowers, speak for me," neatly inscribed within. One of our great botanists suggests, with a more philosophical and less poetical mind, that the real signification of the name is, after all, due to the bright blue tint and yellow eye of this charming flower, which, if once seen, is not likely to be forgotten. Nevertheless, we remain fuithful to the generally-received tradition, and in justification of it, call to remembrance that as early as 1465, when a joust was held in which Lord Scales, brother to the Queen of Edward IV., took part, the fair ladies of her court presented to that favoured knight a collar of gold, enamelled with "Forget-menots." I am not aware that this much-prized plant has ever been used in the arts of life, yet it is a household favourite, and reminds us that there is in the luman mind a deep and close association between the external beauty of nature and the strongest feelings of our hearts. Who but loves to meet, as Colerilgre las it,-

"By rivulet or wet rondside, That blue and bright-eyed flow'ret of the brook, Hope's gentle grem, the sweet Forget-me-not." 


\section{IIENBANE, OR HOGSBEAN.}

(Fig. 63.)

\section{HYOSCYAMUS NIGER.}

THis belongs to the family Solanacer, which is chiefly characterized by its poisonous properties. Wherever there is a patch of waste ground, there may be seen the dull-yellow blossoms of this dangerous plant. Its whole appearance, and the peculiar faint and disagreeable odour emitted by it, wonld seem almost to indicate its nature; yet the narcotic principle yielded by it is most valuable as a medicine, properly administered. It is a coarse, erect, branching annual, about one or two feet high, more or less hairy and viscid. The leaves are ratler large, sessile; the upper owes clasping. The calyx is short when in flower, but points round the fruit, and is then an inch long, strongly veined, with five broad, stiff, almost prickly lobes; the stem ovate, and irregularly pinnatifid. The flowers are remarkable for their purple veins, which give them a curious appearance when in blossom, and which cause the whole plant to be peculiarly adapted for a process now not uncommon in ornamentation. If soaked for a long time in water, with some chemical agent, the soft parts of a plant decompose and disappear, leaving only the woody fibrous parts entire and bleached. These form what are known as skeleton plants, and I liave seen several extremely beautiful specimens of the Henbane treated in this way, which indicates that the 
woody tissue is abundant in this plant. The narcotic properties of the Henbane are most strongly developed when the flowers have just fallen and the seeds are ripening. Lightfoot mentions that a few of these seeds have deprived a man of his reason and the use of his limbs; nevertheless they are frequently smoked in a tobacco-pipe as a cure for toothache. The expressed juice of the plant, forming an extract, is recognized in the "Pharmacopoia," and in some cases is very valuable where other anodynes are inadmissible. A curious effect is produced on the system by these vegetable poisons, somewhat like intoxication-excitement, restlessness, and irritability are often the first symptoms of their action. A story is told of a gardener and his wife, who lived happily and in perfect contentment, until one day the good man, wishing to dry some Heubane plants, hung them up in his bedroom for that purpose. From that hour his domestic peace vanished; his wife became a perfect shrew, and he returned each curtainlecture with interest. Happily Sir Cresswell Cresswell's court was then unknown, or the speedy separation of the discontented parties would have rendered the solution of the mystery for ever impossible. Accidentally the Henbane was removed, and peace was restored. Each felt that, after all, the other was not to blame, and with returning amiatility came increased happiness. It remained, however, for philosophers to trace the connection between the baneful effects of the Henbane exhalations and the irritable, quarrelsome condition of those who breathed them. 
DEADLY NIGHTSHADE, OR DWALE.

(Fig. 64.)

\section{ATROPA BELLADONNA.}

THIS is one of our most poisonous native plants, and must be clearly described in order to be avoided. It belongs to the family Solanacex, and is an erect, smooth, or rather downy herb, with a perennial root, stock, and branching stem. The leaves are stalked, rather large, ovate, and entire, with a smaller one usually proceeding from the same point, often so suall as to look like a stipule. The flowers are solitary, on short peduncles in the forks of the stem, or the axils of the leaves. The flower is of a pale purplish-brown colour, bell-shaped, nearly an inch long. The stamens are shorter, with distinct filaments. The berries are large, and of a shining black appearance, which frequently tempts children into eating them, to their injury. The modern name Belladonna, refers to the practice of the Italian belles, who make use of its properties to enhance their personal charms. A portion of the extract, when placed in contact with the pupil of the eye, causes it to dilate, and gives a brilliancy and lustre to these speaking orbs, which is much coveted and admired. I am told that this practice is not confined to the land of cloudless skies and southern breezes, but that in our own country the preparation is to be seen on the toilette-tables of our fashionable ladies. Happily this property is 
turned to good account by modern science, and in examinations of the eye it is found to be of great service in dilating the pupil, as well as previous to the operation for cataract. Numberless are the instances where death has ensued from partaking of this plant or its berries. The very powerful nature of its poisonous qualities has directed the attention of modern professors of Materia Medica towards it, and at this time it is considered to be a valuable medicinal agent. A medical friend of ours, enthusiastic in the discovery of hidden truth, not long ago nearly fell a victim to lis own experiments on the action of an extract of the leaves of Atropa Bellacionna. He had previously made known his belief that animal charcoal is the best and safest antidote to vegetable poisons. He was, however, too much under the influence of the poison to think of his own remedy, and it was only by the timely interference of a friend, who knew of the discovery, that his life was saved. It is a fivourite remedy in homoopathic medicine; but as the doses given are inappreciable, it would be difficult to trace any results from their administration. The poisonous froperties of this plant have long been known, as uppear's fiom its having been used by the Scotch under Macbeth to poison the Danes. Our great poet Shakspeare, with his wonderful appreciation of natural phenomena, refers, undoubtedly, to the same plant in Banquo's speech,- "Or have we eaten of the insane root that takes the reason prisoner?" Paroxysms of madness are among the curious and direful effects of this plant on the system, to which it is supposed Plutarch refers in his account of the strange 
and disastrous results produced on Marc Antony's soldier's, "from tasting unknown herbs" when distressed for provisions.

To the same genus of plants belong the Mandrakes, Atropa mandragora, the roots of which are superstitiously connected with numerons fancies, and are still sold on the continent of Europe as ingredients in love-philtres and charms. Some writers recognize them as the mandrakes of Scripture.

\section{WOODY NIGHTSHADE, OR BITTER-SW EET.}

(Fig. 65.)

\section{SOLANUH DULCAMARA.}

Tris belongs to the same family of plants as our last example, and is believed to have the same poisonous properties, in both fruit, leaves, and stem. 'This has, however, been disputed of late, and the Professor of Materia Medica at University College considers all the Solanums as perfectly innocuous. It has a shrubby stem, with climbing or straggling branches, often many feet in length, bat dying far back in the winter. The leaves are stalked, ovate, or lanceolate, two or three inches long, usually broadly cordate at the base and entire, but sometimes with an additional smaller lobe or segment on each side, either quite smooth or downy on both sides, as well as the stem. The flower's are rather small, blue, with yellow 
anthers, in loose branches, shorter than the leaves. The berries are small, round, or ovoid, and of a bright-red colour. It is to be found in hedges in shady, moist situations, all over England and Ireland -more rarely in Scotland. As a medicine, this plant has been used both internally and externally; it is recommended in asthma and many other diseases.

\section{GERMANDER SPEEDWELL.}

(Fig. 66.)

\section{VERONICA CHAMADDRYS.}

This is one of the prettiest of our wayside plants, belonging to the family Scrophulariaceæ. There are so many species of Veronica, that they are somewhat difficult to distinguish from each other. The lovely blue flower, "The Celestial Bird's-eye Blossom," as it has been called sometimes, causes it to be mistaken for the true "Forget-me-not," but those who study both will soon learn to distinguish them. The leaves are shortly stalked, ovate, cordate, crenate, and hairy. The flowers spring from the leaves on rather long stalks, and have a five-cleft calyx. The common name of Speedwell is well chosen, for what so cheering to the wayfarer as its bright-blue flowers peeping out from the hedgerows to greet him as he passes by"Stars that in earth's firmanient do shine." The whole of the Veronicas have had their day in rustic medicine, and perhaps a larger list of virtues belongs to the 
Germander Speedwell than any of the rest. As a substitute for tea it is considered excellent by some writers. The Emperor Charles V. is said to have used it as a remedy for gout, and in cancer it is recommended by old Gerarde to be given in "Good broth of a hen," a prescription in which possibly the vehicle may have had more efficacy than the medicine.

In a pleasant little book by Mr. Hibberd, called "Brambles and Bayleaves," an anecdote connected with this charming little plant is given from the life of Rousseau, which is too interesting to remain unquoted here. "During the earliest and happiest days of Rousseau's life, he was walking with a beloved friend on a calm, serene, summer evening. The sun was setting in all its glory, spreading sheets of fire over the western sky and upon the unrippled surface of the lake, making the water still more transparent with a vivid and glowing light. The friends sat on a soft mossy bank, enjoying the calm loveliness of the scene, conversing on the varied phases of human life in the unaffected sincerity of true friendship. At their feet was a bright tuft of the lovely Germander Speedwell, covered witlr a profusion of brilliant blue blossoms. Rousseau's friend pointed to the little flower, the Veronica Chamcedrys, as wearing the same expression of cheerfulness and innocence as the scene before them. Thirty years passed away! Careworn, persecuted, disappointed, acquainted with poverty and grief; known to fame, but a stranger to peace, Rousseau again visited Geneva. On such a calm and lovely evening as thirty years before, he had con- 
versed with the friend of his bosom, and had received a lesson from the simple beauty of a flower, he again was seated on the selfsame spot.

"The scene was the same! The sun went down as before in golden majesty; the birds sang cheerfully in the soft light of eventide; the crimson clouds floated solemuly in the western sky, and the waters of the lake were calm as before. But the house wherein the first feelings of love and friendship, and the first fruits of his genius had budded, was now levelled with the ground. His dearest friend was sleeping in the grave. The generation of villagers, who had partaken of the bomty of the same beneficent hand, had passed away, and none remained to point out the green sod where that benefactor lay. He walked on pensively; the same bank, tufted with the same knot of bright-eyed speedwell canght his eye, the memories of past years of trouble and sorrow came upon him; he heaved a sigh and turned away, weeping bitterly."

\section{SNAPDRAGON.}

(Fig. 67.)

\section{ANTIRRHINUII IIAJUS.}

This is a plant belonging also to the family Scrophulariceæ. It is frequently cultivated in gardens, but also grows wild on old walls and stony places, and on chalk cliffs on the south of England. The leaves are narrow, lanceolate, or linear entire. The flowers are litrge, of a purplish-red colour, or variegated with 
white. The corolla is above an inch long, opening like a mouth when pressed between the finger and thumb. They form perfect insect-traps: numbers of these little creatures, attracted by the sweet nectar to be found within, enter the treacherous tube, but on seeking to return, find their egress effectually prevented. Those, however, who are clever enough to gnaw a hole through the side of their prison escape uninjured. Gmelin says, that in Persia an excellent sil, equal to that of the olive, is procured from the seeds of the A. majus; and Vogel observes, that the common people in many countries attribute some supernatural influence to this plant, believing it to have the power of destroying charms, and rendering maledictions of none effect. All the varieties of Suapdragon are peculiarly able to resist the effect of great droughts, and supply vegetation and beauty in situations where other flowers would perish from the power of the sun's rays.

\section{GREAT MULLEIN.}

(Fig. 68.)

\section{VERBASCUM THAPSUS.}

Tuis plant belongs to the natural family Scrophulariacere, and is a stout, erect biennial, two to four feet high, clothed with soft woolly hairs, which circumstance I believe has given rise to its name Verbascum, being a corruption of barbascum, or bearded. The leaves are oblong, pointed, slightly toothed, naz- 
rowed at the base into two wings running a long way down the stem, the lower ones often stalked, and six or eight inches long or more. The flowers are in a dense woolly terminal spike, a foot long or more. The corolla is yellow, slightly concave; the stamens are five in number, three hairy, the other two longer and smooth. The whole plant is very showy and attractive when growing in perfection, as it sometimes does on open moors and commons. The common name Torch-blade, or King's Taper, may have arisen from its candle-like appearance when growing by itself, pointing straightly upwards, and with its flamelike crown of flowers. Some authors account for these common names rather by the fact, that the woolly covering, which is still collected for tinder, was at one time used as wicks for taper's, especially for those employed in religions services; the very trouble entailed in collecting the material seeming to recommend it for this purpose in a church where bodily sacrifices and penances are enjoined. The Verbascum was formerly held in high repute as a medicine in disease of the lungs; it possesses some mucilaginous sedative qualities, which caused the old herbalists to believe in it. It is one of the many herbs said to stupefy or poison fish. According to an old writer, its ashes, made into soap, will restore hair which has become grey to its original colour. 


\section{RED HEMP-NETTLE.}

(Fig. 69.)

\section{GALEOPSIS LADANUM.}

THis is a pretty and not uncommon plant, belonging to the natural family Labiatw. It flowers during the whole summer and autumn in gravelly and chalky corn-fields. It is seldom above eight or nine inches high, with very spreading falling branches, covered with soft short down. The leaves are shortly stalked, narrow, ovate, or lanceolate, and very coarsely toothed. The flowers are variegated with red and yellow, sometimes nearly white; they grow in whorls around the stem, and are remarkable for the very pointed, long teetl of the calyx; which, however, are more marked in the common Galeopsis, G. Tetrahit.

All the British species of Hemp Nettle are pretty plants. The large flowered species, $G$. versicolor, is much more beautiful than our example, but is much less common in England. In the Highlands of Scotland it is abundant. Rare also is the downy Hempnettle, G. villosa, and is only recognized as a variety by some writers. 


\section{BLADDER-WORT}

(Fig. 70.)

\section{UTRICULARIA VULGARIS.}

The Bladder-wort is a pretty aquatic plant, abundant in our pools and water-channels, belonging to the family Lentibulaceæ. It is very remarkable for the buoy-like vescicles which are developed on its immersed leaves, and which serve to float the plant above the water. At certain seasons, the whole plant is submerged, and then, if we examine these vescicles we find them filled with water; gradually air becomes generated in the vescicles, expels the water, and the apertures are closed by a curious valve, so that the plant now becomes bunyant, and rises to the surface ; the flowers expand, the seeds ripen, and then the living energy of the plant seems exhausted-air no longer fills the vescicles, but water takes its place, the plant sinks to the bottom, and the seeds are sown in their most fitting soil. The flowers are rather large, and of a yellow colour. The corolla has a short, conical, more or less curved spur. The leaves are pinnate with numerous segments. In the eastern counties of England the Bladder-wort is not uncommon, and in many other localities it has been found, although it must be considered as rather rare. 


\section{SEA MILKWORT}

(Fig. 71.)

\section{GLAUX MARTIMA.}

Sea Milkwort is common on nearly every sea-coast. It belongs to the family Primulacer, and is conspicuous from its rose-coloured tiny flowers, resting in the axils which its ovate fleshy opposite leaves form with its branched and procumbent stem. It is very pretty while growing, and is associated with some of our pleasantest sea-side rambles, and though scarcely attainable without incurring wet feet, it is worth the inconvenience; and those who are in health must not shrink from searching the salt marshes on the coast, for many very charming botanical treasures find their homes there.

\section{PRIMROSE}

(Fig. 72.)

\section{PRIMULA VULGARIS.}

The Primrose is a type of the natural order Primulacex. We select this plant because it is the real true primrose of our childhood-not the cowslip, with its deep yellow cups and nodding flowers-nor the oxlip, with its larger but paler blossoms; but the sulphurcoloured primrose with which we all associate the early 
days of spring, and the first ramble in the meadows or by the hedge-side. The first Prinmose of the year is prized and welcomed, but when the thick tufts of its blossoms are seen, then we feel that spring is really come, and we almost fancy that no other flower ever looked so lovely or so fresh and pure. Botanically, the Primrose is an excellent example of a plant with regular monopetalous corolla, and is a good specimen for a first lesson in botany. Pretty flower as it is, all animals reject it as food excepting the pig. It seems, however, not wholly objected to by man, or woman either, for I lately saw a receipt for a primrosepudding. A kind of wine, too, is made from the flowers, something like cowslip wine, but more delicate in flavour.

\section{MONEYWORT, OR CREEPING LOOSE- STRIFE.}

(Fig. 73.)

\section{LISIMACIIIA NUMMULARIA.}

THIS is a pretty little plant, to be seen in all hedges, or on banks, during the summer and autumn, throughout England. It belongs to the natural family Primulacer. The stems are prostrate, trailing to the length of one or two feet, often rooting at the nodes. The leaves are round, on very short stalks, looking almost like pieces of money; the flowers yellow, large and handsome, on short stalks-the segments of the calyx are pear-shaped. With a microscope, little pedicillate glands may be seen covering the blossoms and stamens. 


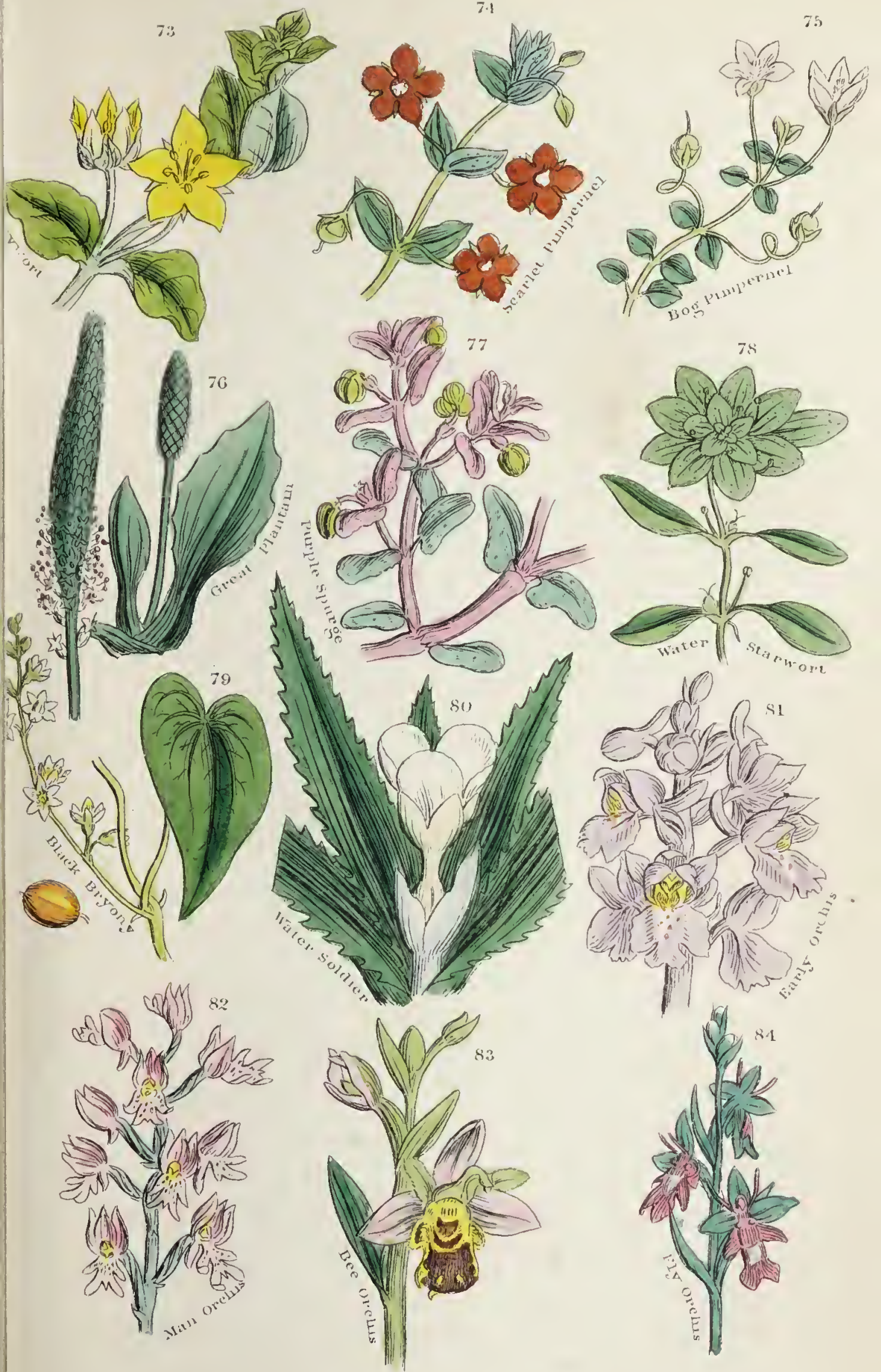





\title{
PIMPERNEL, OR POOR MAN'S WEATHER-
}

\section{GLASS.}

(Fig. 74.)

\section{ANAGALLIS ARVENSIS.}

\begin{abstract}
"Whose brilliant flower, Closes against the approaching shower, Warning the swain to sheltering bower,
\end{abstract}

From liumid air secure."

Tiris well-known and very attractive little plant belongs to the family Primulacere, and is a neat, muchbranched, procumbent annual, six inches to near a foot long, with opposite, broadly ovate, sessile and entire leaves. The calyx divisions are pointed. The corolla is rotate, and usually of a bright red colour ; sometimes it is white or pale-pink, or blue. The blue variety is as common in central and southern Europe as the red is with us, but in England it is very rare. I have, however, found it in Suffolk, in a lane near Felixstowe, where the red pimpernel grows most luxuriantly. The extreme sensitiveness of this pretty little plant to a change of atmosphere canses it to shut up its petals at the approach of rain. In fine weather it remains open from about eight in the morning till four in the afternoon. It is a common weed in the valley of the Nile, and its botanical name, which is derived from the Greek, signifies a "reviver of the spirits," in allusion to the medical and magical properties for which it was at one time highly valued. 
At present its only use seems to be as a potherb, and it is also sometimes-more especially on the Continent - eaten as a salad.

\section{EOG PIMPERNEL。}

(Fig. 75.)

\section{ANAGALLIS TENELLA.}

THis is a rarer plant than the former species, but is equally beautiful. It is a creeping, delicate perennial plant, with very small heart-shaped or circular leaves. The flowers are very elegant, of a pale-pink colour, on long slender stalks. The corolla is very delicate in texture, and the stamens are surmounted with very woolly filaments. It flowers throughout the summer, and must be looked for in damp, boggy places, on wet nossy banks, or by the side of rivulets. It is spread over the greater part of Britain, but chiefly in the west.

\section{PLANTAIN, OR WAY-BREAD.}

(Fig. 76.)

\section{PLANTAGO MAJOR.}

Trovgr not an attractive-looking plant as we generally see it by the wayside, it is so closely associated with almost every walk along a country lane, or even ligh-road, that it can scarcely escape notice. The leaves are erect or spreading, broadly ovate, entire or toothed, on longish channelled stalks. The peduncles 
are usually longer than the leaves, bearing a long slender spike of sessile flowers. The sepals are green in the centre, the stamens longer than the corolla; the whole flower is small, white, with pinkish anthers. In general the Plantains are regarded merely as troublesome weeds. Their leaves are eaten by some animals, but contain very little nutriment. The conmon name of $P$. major is undoubtedly Way-bred, not Way-bread, as it is usually spelt, from its frequency by the wayside, seeming as if bred on the road. This plant has a peculiar tendency to follow the migrations of man, as if domestically or sympathetically attached to the human race, and has followed our colonists to every part of the world; so that it has been named by the natives in some of our settlements "The Englishman's foot," for with a strange degree of certainty it is found wherever our countrymen have trod. It is a favourite food with birds, and nothing delights them more when kept in confinement than a supply of the long stalks of plantain to pick at. In the summer, when a supply of other green food can be found for our favourites, the plantain is not so much sought for ; but it should be gathered and laid by in store for the winter, when it will be a treat to the little inhabitants of our aviarius. Bruised plantain-leaves are esteemed an excellent remedy for cuts and bruises, and also as an application to the bites of stinging insects. In the Highlands of Scotland an ointment is made from them, which is said to be very efficacious. There are five British species of plantain, some of which have medicinal reputation from their mucilaginous properties. $P$. coronopus has been eaten as a salad, but is too bitter to be pleasant. 


\section{PURPLE SPURGE. \\ (Fig. 77.) \\ EUPIIORIA PEPLIS.}

THIs is a handsome plant belonging to the family Euphorbiacer. It is found only on the sea-coasts, and is becoming rare in Great Britain. It loses all its leaves before flowering, when the short main stem divides close to the base, so that the whole plant appears to consist of the forked procumbent branches lying on the sand in patches from six inches to a foot in diameter. The whole plant has a reddish or purplish hue, and that peculiar glaucous appearance so general in seashore plants. The leaves are opposite, half oblong, heart-shaped, and very thick, with small stipules at their base. The flower heads are very small. The genus Euphorbia is a very extensive one; there are fourteen or fifteen British species, nearly all of which have an acrid poisonous secretion. A notion prevails that milk is an antidote to this poison, but without reason, as we read in Withering's botany of a strong youth who was poisoned by drinking milk in which the plant had been boiled. As a cure for warts we can believe in the virtues of the Spurge ; its astringent or acrid qualities may have some powerful effect as an external application; but old Gerarde's advice is certainly worth quoting, where he says: "These herbes by mine advise would not be received into the body, considering that there be so many good and wholesome 
potions to be made with other herbes that may be droken without perill." The ancient Britons nsed the Euphorbia to poison fish, which practice is continued by the Abyssinians. It is said that the fish thus killed are good for food, but this is doubtful, as there are instances of people being poisoned merely from drinking the milk of a goat which had fed on the Euphorbia.

\section{WATER STAR-WORT.}

(Fig. 78.)

\section{CALLITRICHE VERNA.}

This is the representative of the only genus of Water Star-worts - Callitrichaceæ - in Great Britain. This pretty plant is very suitable for the aquavivarium, and is found in stagnant and slowly-running water all over the country. It is easily known by its upper leaves floating on the water, and two or three pairs of them forming a little green star, hence its name. This plant forms a beautiful object under the microscope, for its leaves and stem are covered with very minute rosette-shaped bodies, which seem to supply the place of hairs in other plants. There are other species of Water Star-wort in England, but they are much more rare. 


\section{BLACK BRYONY.}

(Fig. 79.)

\section{TAMUS COMNUNIS.}

This is an elegant climbing plant, which through the whole summer may be seen festooning our hedges and bushes. Its bright shining heart-shaped leaves clothe the trunks of many of our sturdy old trees with a verdure unequalled by any other plant. The lightness of its twining stems prevents it from injuring the branches within its grasp, for they have not the firmness or strength of the ivy, which is sometimes too close in its embrace. ${ }^{*}$ The flowers are unattractive and small, but the berries of the Bryony, hanging like clusters of wild green grapes during the summer, and changing into brilliant scarlet balls in the autumn, are objects of great beauty. They are very poisonous, and must not mislead by their charming appearance. The early shoots of the plant, however, have frequently been boiled and eaten, it is said, with great relish and with no bad results. The roots have a black colour externally, hence the name of the plant. The interior is white and full of starch, which is, however, bitter

* The family Dioscoracez, to which the Tamus belongs, includes the yams; the tubers of which are well known as an article of food in South A frica and Mexico, and have lately been extensively sent to England, but, as yet, are not very popular, so great is the prejudice against any innovation on our old habits in diet. 
and unwholesome. The acrid pulp of these roots has been used as a stimulating plaster.

\section{WATER SOLDIER.}

\section{(Fig. 80.) \\ STRATIOTES ALOIDES.}

This plant, so named from its sword-shaped spring leaves and fancifully military appearance, is a very ornamental aquatic plant. It belongs to the family Hydrocharideæ, and is found very abundantly in lakes and watery ditches in the east of England. In Norfolk and Suffolk it is very plentiful, and is an interesting plant to observe. It remains submerged during the greater part of the year, but raises itself to the surface on special stalks during the season for fertilizing the seeds. It forms a favourite hiding-place for multitudes of aquatic insects, as may be seen if a plant be quickly raised out of the water. The whole plant seems to resemble an aloe more than any thing else, and is equally rigid and sharp in its leaves.

\section{EARLY ORCHIS. \\ (Fig. 81.) \\ ORCIIIS MASCULA.}

We now come to a most attractive and beautiful group of wild flowers, difficult to describe, and very puzzling to the young botanist, but easily recognized 
by any one who has seen and gathered them, even without knowing their scientific distinctions. The Early Orchis blossoms in the months of May and June, and may be found in any meadow or moist wood throughout Great Britain. The stem is a foot or a foot and a half high, bearing numerous showy flowers, in a loose spike, from three to six inches long, varying in colour from a pinkish purple to flesh-colour, or even white. The leaves are broad and often spotted with purple. The bracts are coloured nearly as long as the ovary, with a single rib. The upper sepal and the petals converge over the ovary, but the lateral sepals are spreading, or turned back. The lip is scarcely longer than the sepals, often slightly downy in the centre, turned back on each side with three short lobes, the middle one the largest. The tubers of all the Orchis plants contain a good deal of farinaceous nutritious matter, consisting, according to modern chemists, of a principle called Bassorin. This substance is commonly known as saloop, or salep, a word derived from the Persian name of the Orchis, which, according to Forskhale, is sahleb. When boiled in water, it used to be sold at the corners of the streets in London, and was a favourite drink with coalheavers, porters, and other hard-working men. It is still highly esteemed in the East; and during the Great Exhibition of 1851 was exhibited and sold as a beverage. It is said to contain more nutritious matter according to its bulk than any other vegetable substance, and that an ounce a day will sustain a man; hence it is a favourite food, from its portability, with pedestrian travellers in wild deserts and uninhabited countries. 


\title{
115
}

\section{MAN, OR MILITARY ORCHIS.}

\author{
(Fig. 82.)
}

\section{ORCHIS MILITARIS.}

THis is a handsome species of Orchis, from one to two feet high, with entire tubers. It is difficnlt to say what fancy has given rise to the name; the red colour of the flowers or the shape of the root may have suggested a soldier-like resemblance. The leaves in the lower part of the stem vary from broadly oval to oblong; they are usually three to five inches long. The flowers are numerous, in a dense oblong spike, with short bracts. The sepals are red or purple, and converge over the petals and column in the shape of a helmet. The lip is more or less spotted with rough, red points, and four-lobed, or rather three-lobed, with two entire lobes, and a third one divided in the middle into two, with a small tooth in the cleft or notch. It is found on chalky hills, on the borders of woods, and in hilly pastures. Near London it should be looked for about Dorking, Rochester, and Northfleet. There are very many other British Orchids; all of them are pretty and attractive, and one, $A$. conopsea, has a fragrant, agreeable scent. 


\section{BEE ORCHIS.}

(Fig. 83.)

\section{OPHRYS APIFERA.}

Turs plant belongs to the family Orchidaceæ, and to a section of that family most curiously eccentric in the forms of its flowers, very closely resembling the Orchies with the habits, tubers, and foliage of that group of plants; but the flowers of Ophrys have no spur, and the lip is usually very curved, resembling, more or less, the body of an insect. They are often called Orchis, though not properly belonging to that genus. The Bee Orchis blossoms in July, in dry pastures, in chalky and limestone districts. In the eastern counties of England it is not uncommon. It has a brown, velvety lip, variegated with yellow, which resembles the body of a bee; the purplish petals look like the expanded wings of an insect which had just settled on the stem of the flower. Langhorne's pretty lines have been often quoted, but are too descriptive to be omitted here :-

"See on the flow'ret's velvet breast

How close the busy vagrant lies, His thin-wrought plume, his downy breast, The ambrosial gold that swells his thighs.

Perhaps his fragrant load may bind

His limbs-we'll set the captive free;

I sought a living bee to find, And found the picture of a bee." 


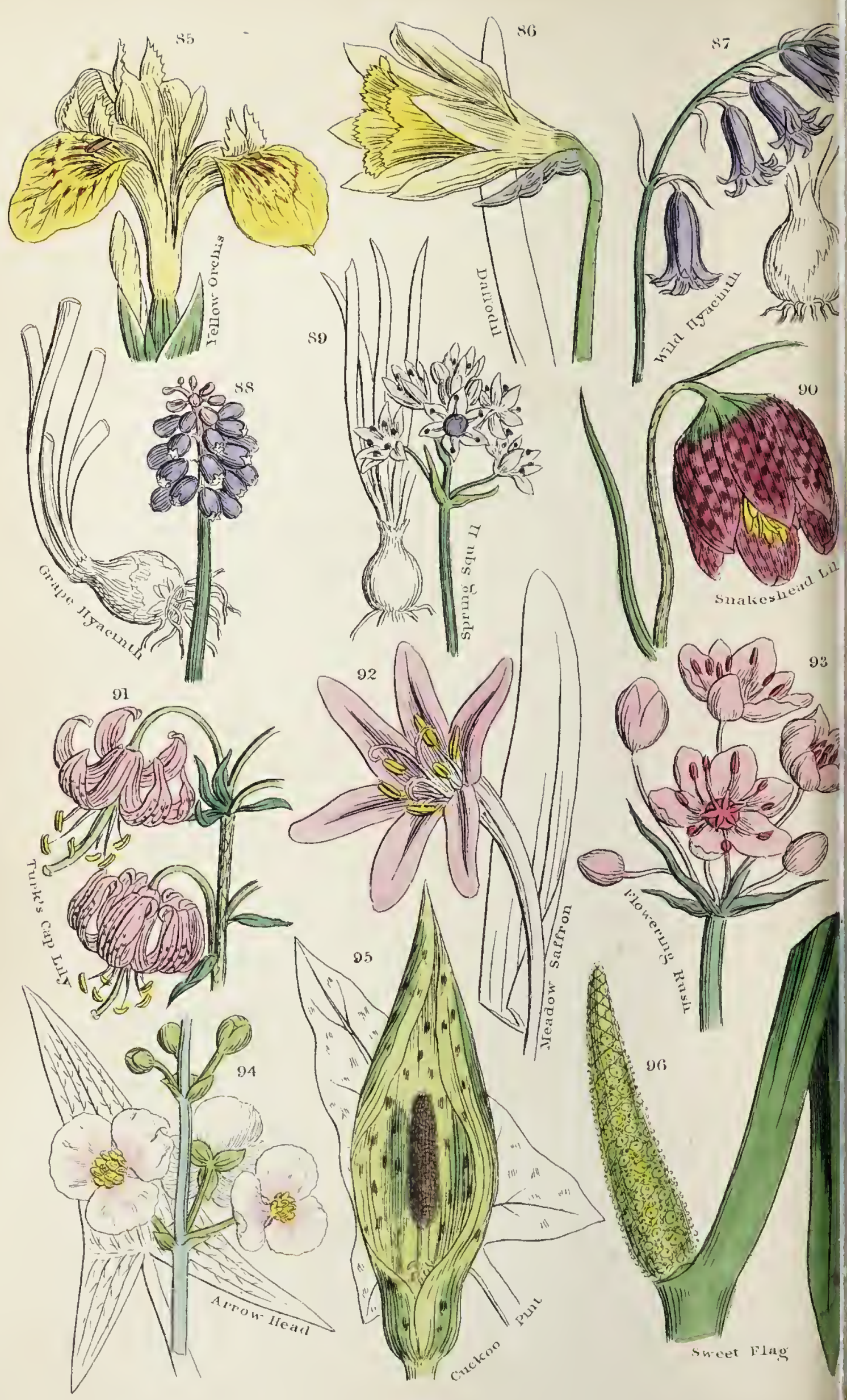




\title{
FLY ORCHIS.
}

(Fig. 84.)

\section{OPHRYS MUSCIFERA.}

THis is a much more delicate, slender plant than the Bee Orchis, with narrow leaves and a slender spike of three or four flowers. The sepals are whitislgreen. The lips brownish-purple, oblong, convex, and with pale-blue or white marks in the centre; the two lateral lobes turned down; the central one large, with a deep notch. The blue spot upon the base of the middle segment of the lip contributes much to the resemblance of the flower to a fly, which, indeed, is singularly close. We have also in this genus of plants the Spider Ophrys; and there is also the Butterfly Orchis, and the Lizard Orchis; these latter names are not, however, so well applied as those of the bee and fly.

\section{YELLOW FLAG-WATER FLAG.}

\author{
(Fig. 85.)
}

\section{IRIS PSEUDACORUS.}

The Frag plant is found in wet meadows and marshes and along water-courses throughout Europe. It belongs to the family Iridaceæ. The stem is about two feet high. The lower leaves are often much longer, 
stifi and erect, and of a pale-green colour; the upper leaves are shorter. The flowers proceed from a sheathing bract, are large, erect, and of a bright-yellow colour, two or three together. The stigmas are petal-like, rather longer than the inner segments, two-cleft at the top, with a short scale-like appendage inside at the base of the lobes. The capsule is green, from two to three inches long, with numerous pale-brown seeds. The medicinal uses of this plant are various. The juice of the fresh root is very acrid, and acts powerfully. Withering mentions a case where it was given to some swine bitten by a mad dog, and they escaped the disease; while some others, bitten by the same dog, died with all the symptoms of hydrophobia : but I need not say that unless some evidence existed of this plant possessing active properties, Withering's cases do not prove any connection between the medicine and the cure. It is on such reasoning as this that the fallacies of Homoopathy are based. The roasted seeds are said to be a good substitute for coffee, when carefully prepared. Few plants can exceed the Iris in elegance of form; in our gardens it is a great ornament, and by the sides of streams and lakes it should always be encouraged

\section{"Amid its waving swords,}

In flaming gold the Iris towers."

The Iris is undoubtedly the original of the Fleur de lys in the arms of France, and in many pieces of sculpture in which this device is introduced, it is not difficult to recognize it. The plant was considered in ancient times as peculiarly sacred to the Virgin Mary, as 
shown in the old legend of the knight who, more devout than learned, could never retain in his memory more than two words of a prayer to the Lady Mother. These were Ave Mario, and with these he constantly addressed his prayer to Heaven. Night and day his prayer continued, until the good old knight died and was laid in the chapel yard of the convent, when, as a proof of the acceptance of his brief though earnest prayer, a plant of Fleur de lys sprang up on his grave displaying on every flower in golden letters the words Ave Maric. The sight induced the monks, who had despised him during his lifetime on account of his ignorance, to open his grave; and there they found the root of the plant resting on the lips of the good old soldier who lay mouldering there.

In Britain we find but two really native species of Iris, I. pseudacorus and I. foetidissima, the smell of the crushed leaves of which is thought to resemble roast beef; tastes differ, however, for Linnæus, when he gave it the specific name, must have regarded it as anything but savoury in smell. The juice is sometimes used to excite sneezing in cases of headache, but it is a very unsafe practice.

\section{DAFFODIL-DA FFY-DOWN-DILLY. (Fig. 86.) NARCISSUS PSEUDONARCISSUS.}

THrs is a well-known pretty plant, belonging to the family Amaryllidaceæ. The name Narcissus seems to 
be wrongly applied to this species, as it belongs, no doubt, to the Narcissus poeticus of the Greeks, which has a flower with a very powerful scent, a quality from which the daffodil is free. The Narcissus was consecrated to the Furies, who stupified their victims, hence Sophocles calls these flowers "garlands of the infernal gods." The fable of the youth Narcissus, after whom the plant is named, is well known to everybody; how he fell in love with his own image reflected in the water, and pined away until he was changed into the pale flower which rightfully bears his name. Our present specimen, the Daffodil, bears simply the old English name affo dyle, which signified "that which cometh early," and it was long before the word was corrupted into daffodil. It is one of our earliest spring flowers; it is rare in Scotland and Ireland, but in the south-west of England its yellow or pale lemoncoloured blossoms may be seen covering acres of land. In Cornwall they are still called Lent lilies. The root, and, to some extent, the whole plant, is poisonous, yet a useful spirit is distilled from it, which has been used as an embrocation, and also given as a medicine. Most welcome are these pretty spring flowers to us all, and in cottage gardens they add beauty and grace without expense or trouble, for they grow under almost any conditions.

"When the vales are decked with daffodils,

I hail the new reviving year, And soothing hope my bosom fills." 


\section{WILD HYACINTH.}

(Fig. 87.)

\section{HYACINTHUS NONSCRIPTUS.}

This well-known pretty plant is known to every child who has rambled in the fields and woods in search of wild flowers. It is sometimes called the Harebell, or Bluebell, but is quite distinct from the Campanula rotundifotia, the true Bluebell of Scotland. It belongs to the family Liliacere, and by some botanists is not called Hyacinth at all, but is placed with the squills, and is called Scilla nutans. It is the child of the spring and the denizen of the woods, whilst the Campanula is the pride of harvest time, and flourishes in exposed situations. The wild Hyacinth has a white bulb, full of clammy juice. The leaves are linear, shorter than the flower-stem. The stem is about a foot high, angular, with a terminal one-sided raceme of drooping blue flowers, each with a small narrow bract at the base of the pedicel. We all know the beautiful sweet-scented Hyacinth of the gardens, but nothing can be more charming than the masses of these wild blue Hyacinths sometimes seen in sheltered places, under the spreading branches of trees, forming almost a living carpeting to some shady nook. In Kew Park, acres of the green grass is changed from green to blue by the presence of these lovely blue flowers. The Hyacinthus nonscriptus is not the true Hyacintl of ancient Greek story; that is supposed 
to have been a species of Lily, which sprung from the blood of the beautiful boy Hyacinthus, whom Apollo unfortunately killed; so that though we cannot claim for our favourite a place in classic lore, we think that its own unassuming beauty, delicate scent, and the early associations it must recall to all hearts, will justify its introduction here. The juice contained in the root of the Hyacinth is sometimes used as starch or gum. At one time, when stiff ruffs were worn, it was much in request. It also served the purpose of the bookbinder, to fasten the covers of books securely.

\section{GRAPE HYACINTII.}

(Fig. 88.)

\section{MUSCARI RACEMOSUM.}

The Grape Hyacinth belongs to the order Liliaceæ, but may be easily distinguished from our common Hyacinth, although belonging to the same family, and flowering about the same time. The leaves are narrow, lanceolate, rather thick, not stiff, from six inches to a foot long, or, when very luxuriant, $1 \frac{1}{2}$ feet long. The stem is usually shorter, with a close terminal raceme, or head of small, dark-blue flowers, looking almost like little berries; a few of the uppermost are of a paler blue, exect, much narrower, and without stamens or pistil. At one time this plant was very much cultivated in gardens. It abounds in sandy soils, and is plentiful in the eastern counties of Eugland. 


\section{SPRING SQUILL.}

(Fig. 89.)

\section{SCILLA VERNA.}

THis plant belongs also to the family Liliaceæ, and is a pretty plant, found chiefly in the north and west coasts of England, near the sea. In Wales it has, however, been frequently met with, and on the east coast of Ireland, but rarely in Scotland. It is a delicate little plant, with a small bulb, and narrow, linear leaves, two to four inches long. The flowerstem is seldom above six inches long, with several small, erect, blue flowers, in a short terminal raceme, almost forming a corymb. The blossoms are bellshaped, but not pendant, and of a bluish-violet colour. The foreign species of Squills have long been celebrated for their medicinal qualities, but I am not aware that any properties of a like kind have been attributed to their British relatives.

\section{SNAKESHEAD LILY, OR COMMON}

\section{FRITILLARY.}

(Fig. 90.)

FRITILLARIA MELEAGRIS.

Turs pretty plant belongs to the Lily tribeLiliaceæ; indeed. this is so beautiful a family of 
plants, that it is difficult not to show a partiality to it when choosing wild flowers "worth notice." The Fritillary is not a common plant; it is found chiefly in the southern and eastern counties of England, and cannot be said to be wild at all in Scotland. The unexpanded blossom, somewhat fancifully, is said to resemble a snake's head; hence its common name. It has a stem about a foot high, with its leaves alternate and linear lanceolate; the single drooping flower, of a dull-red colour, marked curiously with pink and dark-purple; hence the name Fritillaria, from Fritillus, a dice-box - the frequent companion of a cheque or checkered board. It blossoms in April, in meadows and pastures throughout Englond, and is the only British species of the genus. Many handsome foreign species are cultivated in our gardens. The handsome Crown Imperial (Fritillaria imperialis) is a native of Persia, and belongs to the Tulip group of the liliaceous tribe of plantis.

\section{TURK'S-CAP LILY.}

(Fig. 91.)

\section{LILIUM MARTAGON.}

THis belongs to the Tulip group of the Lily family of plants. It is not a common plant in its wild state, though in gardens it is cultivated to great perfection and beauty. It is to be met with, however, on chalk hills and in woody places in the southern parts of England. The scent of the Lily is so powerful as 
to be very annoying to some people, though in this species, and in their wild state, it is not so perceptible. The flower may readily be recognized, from its common name. The petals are reflexed, and turn over, forming a sort of turban, while the stamens appear like a tuft of feathers at the top.

\section{MEADOW SAFFRON.}

(Fig. 92.)

\section{COLCHICUM AUTUMNALE.}

Is the autumn of the year, when all nature seems losing her brilliancy, and the "sear" and yellow leaf" proclaims the approach of winter, this pretty flower forms a gay carpet in the fields and meadows. It may easily be mistaken for a crocus, which, however, belongs to a different family, and blossoms in the spring of the year.

"The Crocus blows before the shrine, At vernal dawn of St. Valentine."

The Colchicum belongs to the family Melanthaceæ, while the Crocus is placed with the Iridacer. The flowers of the Colchicum are large, of a pale-purple colour, and spring up without leaves, forcing their way through the soil, and expanding just above the ground, leaving the tubular part with the ovary and filaments enveloped in membranous sheathing spathes below the soil. Each stalk produces six or eight of these flowers. 
The stamens are six, the ovaries three, each with a long thread-shaped style, and not adhering in any manner to the flower. These are succeeded by the fruit in the form of three little follicles, which slightly adhere together by their inner edge, and in the spring are elevated above the soil by their lengthened footstalk. At this time too the foliage makes its appearance in the form of an erect tuft of oblong shining sheathing leaves. Each follicle contains several oblong seeds. So like is the whole plant to the autumn Crocus, that inexperienced observers may readily mistake one for the other. They may be distinguished, however, by remembering that the Crocus has only three stamens, one style, and an inferior ovary; while the Colchicum has six stamens, three styles, and a superior ovary. The Crocus, too, is perfectly free from those poisonous qualities which distinguish the Colchicum, and render it so useful a plant in medicine. Many species of Colchicum are cultivated for the sake of their flowers, and are badly distinguished by botanists from our specimen, which alone is of any worth in materia medica. So virulent are the poisonous properties of the $C$. autumnale, that the fingers are sometimes benumbed in preparing it, and cattle which have been driven to eat it through hunger have frequently died. It is very important for those who are employed in collecting the plant for medicinal use, to know that the active principle it contains appears to become concentrated in different parts of the plant at different seasons of the year. In June and July the root is in perfection; in September the flowers, and the seeds in the following spring. No vegetable poison has been more advantageously applied 
in medicine than this. Sir Everard Home recommended a tincture of it as efficacious in curing the gout, and it is now even more generally prescribed in rheumatism and gout than in his time. The Hermodactyl of the Greeks is believed to have been a species of Colchicum ; it was celebrated as a remedy for gout in ancient times, and its celebrity has been again revived as an ingredient in the French remedy-"Eau Médicinale."

\section{FLOWERING RUSH.}

(Fig. 93.)

\section{BUTOMUS•UMBELLATUS.}

THIs is a peculiarly elegant plant, belonging to the family Alismaceæ. It is a rush-like plant, with threecornered, sword-shaped leaves, and umbels of handsome rose-coloured flowers containing nine stamens, a peculiarity by which it is immediately recognized among other wild flowers. The roots are regarded in Russia as a specific in hydrophobia, but experiments made with them in this country have not confirmed the accounts given of their properties by Russian physicians, and they do not seem to offer any remedy for this terrible and incurable disease. Well may the name of this beautiful plant signify the "Pride of the Water:" it is one of the most ornamental natural adornments of our lakes and rivers, and in marshy districts, where all looks barren and desolate, there may be seen the bright-coloured flowers 
of the Flowering Rush, by their beauty making "the willerness to rejoice and blossom as the rose."

Withering quotes a couplet, which is expressive and true:-

"Her rosy umbels rears the Flowering Rush, While with reflected charms the waters blush."

\section{COMMON ARROW-HEAD.}

(Fig. 94.)

\section{SAGITTARIA SAGITIIFOLIA.}

This plant belongs to the family Alismaceæ, but differs from some other genera of that family in having unisexual flowers. The leaves, which are arrow-shaped, rise out of the water on very long stalks, the blades six or eight inches long. The flower stem is leafless, erect, and longer than the leaves-bearing on its upper part several distant whorls of rather large white flowers with a purplish tinge at the base of the petals; but so readily do they fall off, that it is difficult to preserve them. The upper flowers are those which contain the stamens, the lower ones on shorter stalks contain the pistils. There is but one locality in Scotland recorded where this Flowering Rush is growing wild; that is somewhere near Paisley. In England and Ireland it is not uncommon, and may be scen in luxuriance on the banks of the Thames, above Putney, during the summer and autumn. The roots of this plant, as well as those of other species, contain an amylaceous 
matter, which is said to form a nutritious food, and is eaten for that purpose by the Chinese and Kalmuk Tartars.

\section{CUCKOO PINT,-LORDS AND LADIES.}

(Fig. 95.)

\section{ARUM MACULATUM.}

CAN we wonder at the deliglit of country children with this curious plant, which seems almost to be one of those things we constantly see in nature, designed to illustrate the grotesque as well as the beautiful. Its large handsome spathe, rising up amidst the elegantly-shaped spotted leaves, forms a fitting shelter for the bright-coloured spadil orflowerstalk, the lord or lady, whichever it may be, within its protecting hood. The plant belongs to the family Aracer, and is the only representative of its family found wild in this country. It would puzzle the beginner in botany to make out the parts of the flower corresponding to those of a Primrose, but after a little study they will be easily understood. The attraction of this curious plant does not cease after the early spring, when the green leaves have faded away, and the lords and ladies and their habitation are no more seen; the little bunch of seedlike bodies about half-way down the coloured spadil, which are in fact the pistils and seed-vessels, in the autumn of the year assume a brilliant red colour, looking like a bunch of coral, as amid the withering 
grass of some hedge-side they attract the notice of the passer-by ; beware, however, of being tempted to taste them. The whole plant is acrid, pungent, and poisonous. The tubers contain a sort of farinaceous substance, which, when freed from its acrid qualities, constitutes a nutritious article of diet. Large quantities are collected in Portland Island and on the dry and sunburnt districts on the banks of the Bristol Channel, and sold under the name of Portland sago. It is largely used to adulterate arrow-root. On the Continent its economical uses appear to be generally known and appreciated. Dr. Withering quotes Wedelius for the supposition that it was on this plant, under the name of Chara, on which the soldiers of Casar's army subsisted when encamped at Dyrrachium. A curious belief is recorded by Gerard as coming from Aristotle, that when bears were halfstarved with hybernating, and have lain in their dens forty days without any nourishment but such as they get by "sucking their paws," they were completely and suddenly restored by eating this plant. Medicinally the Arum had at one time a great reputation in common with all other plants containing acrid or poisonous principles. In rheumatism, gout, and even consumption, its virtues were vaunted, but are now happily discarded. The Arum is one of those plants which exhibits the curious and interesting fact of the vegetable evolution of heat, so evident, that for some

f hours after the opening of the spathe it may be felt with the hand or tested with the thermometer. 


\section{SWEET-ELAG-SWEET-SEDGE.}

(Fig. 96.)

\section{ACORUS CALAMUS.}

IT is, perhaps, well to conclude our selection of "Tild Flowers with one which is worth notice for qualities that do not directly address the eye. Beauty of form and colour are not alone the attractions of the vegetable kingdom, and, as with many other good things in life, we do not become aware of their excellence on a superficial acquaintance. The charming qualities of this our last specimen are undiscovered until we seek for them; not in fact until we have gathered it, and bruised it in our fingers. Then comes forth the pleasant fragrance which gives it its special character. It is a reed-like plant witl a creeping horizontal stem. From this springs many deep-green sword-shaped leaves about three feet long. In the midst of all is a leaflike stem, from below the point of which comes a cylindrical or rather conical spadix of greenish flowers, which are so densely packed together, that the stalk is quite hidden. It grows abundantly in the Eastern counties of England, on the banks of rivers, and was used formerly for strewing the churches on festival days; the custom is, I believe, still preserved in the cathedral at Norwich on certain occasions. The very aromatic smell of this plant is singular amongst our native species. This property has, as might be expecter, been made available in medicine. The roots 
have a strong aromatic smell and a warm pungent taste, consequently they have been prescribed in many ailments where slight stimulants seemed necessary. They constitute the Calamus aromaticus of the shops.

Having now gone over the allotted collection of Wild Flowers, endeavouring to chronicle the chief attractions and virtues of each; I can but feel how little has been said when compared with all that remains unsaid, but felt. I have hesitated in making these little sketches many a time, because I had not the courage to pass by others rudely, whose claims to notice seemed as great as any I have chosen. The whole field of Nature lies before us; I can but hope that if there have been ninety-six interesting thoughts suggested by these our selected examples, they may but be inducements to still further study of the forms and functions of those beautiful creations on which a kind Providence has made so much of our welfare and happiness to depend.- "Consider the lilies of the field, how they grow; they toil not, neither do they spin : and yet I say unto you, that even Solomon in all his glory was not arrayed lize one of these." 


\title{
SYSTEMATIC CHAPTER OF CONTENTS.
}

\author{
$\rightarrow$ \\ FLOWERING PLANTS.
}

CLASS I.

EXOGENS OR DICOTYLEDONS.

\section{$\longrightarrow 00$ \\ Subdivision I.-THALAMIFLOR $巴$.}

PAGE.

Order 1.-RANUNCULACEA.

Ranunculus bulbosus ...... 15

Clematis Vitalba .......... 16

Allemone nemorosa ....... 17

Adonis autumnalis ......... 18

Trollius Europæus ......... 19

Aquilegia vulgaris ........ 20

Aconitum Napellus ....... 21

ORDER 2.-NYMPHAEACE $\mathbb{E}$.

Nymphæa alba $\ldots \ldots \ldots \ldots . . .22$

Order 3.-PAPAVERACEAE.

Papaver Argemone ......... 25

Glacium luteum ........ 27

ORDER 4.-CRUCIFERA. Isatis tinctoria .......... 28

Draba vema ............ 30

Nasturtium officinale ..... 30

Order 5.-CISTACEA. Helianthemum vulgare .... 33

Order 6.-VIOLACEA. Viola odorata
Linum usitatissimum....... 38

ORder 10.-MALVACEE. Lavatera arborea.......... 40 Malva moschata ........... 41 Althra officinalis $\ldots \ldots \ldots \ldots .42$

Order 11.-HYPERICACE压。 Hypericum calycinum ..... 43

ORdER 12.-GERANIACE E. Geranium sanguineum ..... 45 Oxalis $\Lambda$ cetosella.......... 47 


\section{Subdivision II.-CALYCIFLOR E.}

\section{ORDER 13.-LEGUMINOSA.}

PAGE.

Onnnis suinosa $\ldots \ldots \ldots \ldots .48$

Trifolium fragiferum ...... 49

Lathyrus apliaca ....... 50

Order 14.-ROSACEF.

Potentilla reptans ........

ORDER 15.-ONAGRACE无.

Epilobium angustifolium .... 52

Enothera biemis ........ 53

ORDER 16.-LYTHRACEÆ.

Lythrum Salicaria........

55

Order 17.-CUCURBITACEA.

Bryonia dioica

56
Order 18.-CRASSUTACEA. Sempervivum Tectorum .... 57

Order 19.-SAXIFRAGACEA. Saxifraga Hirculus ........ 58 Chrysosplenium alternifolium 60

ORDER 20.-UMBELLIFER E. Sium Angustifolium ...... 59 Hydrocotyle vulgaris ....... 60 Eryngium maritimum ..... 61 Crithmum maritimum ..... 62 Pastinaca sativa ........... 61

\section{Subdivision III.-COROLLIFLORAE.}

order 21.-loranthaceE.

Viscum album ........... 65

OrDER 22.-CAPRIFOLIACEF.

Sambucus nigra ......... 69

Lonicera Periclymenum .... 70

ORder 23.-GALIACEE.

Galium verum ...........

72

ORDER 24.-DIPSACE $邓$.

Dipsacus Fullonum .......

Order 25.-COMPOSITA.

Cichorium Intybus .........

Aster Tripolium ...........

Inula Helenium ..........

Athemis nobilis $\ldots \ldots \ldots \ldots . \quad 77$

ORdER 26.-CAMPANULACE $E$.

Campanula rotundifolia ....

Oruer 27.-ERICACE无.

Vaccinium Myrtillus ........

Erica Tetralix ............

Calluna vulgaris ..........
ORder 28.-AQUIFOLACEA. Ilex aquifolium $\ldots . \ldots \ldots . .83$

Order 29.-GENTIANACE五. Gentiana verna .......... 85 Menyanthes trifoliata ..... 86

Order 30.-CONVOLVULACEAE. Convolvulus sepium ....... 87 Convolvulus Soldanella...... 88

ORUER 31.-BORAGINACEÆ.

Echium vulgare ......... 89 Myosotis palustris ........ 90

ORDER 32.-SOLANACE无. Hyoscyamus niger ......... 93 Atropa Belladonna ........ 95 Solanum Dulcamara ....... 97

ORDER 33.-SCROPH ULARIA$C E$ E.
Veronica Chamadrys....... 98

Antirrhinum majus ....... 100

Verbascum Thapsus ....... 101 
PAGE.

ORRER 34.-LAMIACEAE.

Galeopsis Ladanum ....... 103

ORdER 35.-LENTIBULARIÆ. Utricularia vulgaris ...... 104

ORDER 36.-PRIMULACEA. Glaux maritima
PAGE.

Primula vulgaris ......... 105 Lysimachia nummularia .... 106 Anagallis arvensis .........07 Anagallis Tenella ......... 108

ORDER 32.-PLANTAGINACE $Æ$. Plantago major ......... 108

\section{Subdivision IV.-MONOCHLAMYDE $A$.}

OEDER 33.-EUPHORBIACAE. Euphorbia Peplis
OrDER 34.-CALLITRICHACE. Callitriche verna .......... 111

\section{CIAS II.}

\section{ENDOGENS OR MIONOCOTYLEDONS.}

ORDER 35.-DIOSCOREACEA. Tamus communis ....... 112

ORDER 36.-HYDROCHARIDACEA.

Stratiotes Aloides ........ 113

ORNER 37.-ORCHIDACE AE.

Orchis mascula ......... 113 Orchis militaris $\ldots \ldots \ldots \ldots \ldots \quad 115$ Ophrys apifera........... 116 Ophrys nuscifera ........ 117

Order 38.-IRIDACE无.

Iris Pseudacorus ......... 117

Order 39.-AMARYLLIDACEAE. Narcissus Pseudonarcissus .. 119
ORdER 40.-LILIACE $A$. Hyacintlius nonscriptus .... 121 Muscari racemosum ....... 122 Scilla verna ........... 123 Fritillaria meleagris ...... 123 Lilium Martagon......... 124

ofder 41.- MELANTIIACEA.

Colchicum autumnale ...... 125

Order 42.-ALISMACEA. Butomns umbellatus ....... 127 Sagittaria sagittifolia....... 128

Order 43.-ARACEA.

Arum maculatum ........ 129

Acorus Calamus .......... 131 


\section{N D EX.}

Fig. Page

Aconitum Napellus ...... $7 \quad 21$

Acorus Calamus ....... $96 \quad 131$

Adonis autumnalis ..... $4 \quad 18$

Althrea oflicinalis ....... $22 \quad 42$

Anagallis arvensis $\ldots . .74707$

Anagallis Tenella....... $75 \quad 108$

Alsemone nemorosa...... 3

Anemone, Wood ....... 3

Anthemis nobilis ...... 51

Antirrhinum majus ..... 67

Aquilerria vulgaris ..... 6

Arrowhead ............94

A rum maculatum....... 95

Aster, Sea .......... 49

Aster Tripolium ...... 49

Atropa Belladonna ...... 94

Bedstraw, Yellow.......4 46

Bindweed, Great ....... 59

Bindweed, Sea ........ 60

Bitter-swect .........665

Bladder-wort.......... 70

Blood Geranium ....... 25

Bryony, Black .........79 79

Bryonia dioica ....... 34

Buckbean............ 58

Bugloss, Viper's ....... 61

Butomus umbellatus .... 93

Buttercup ........... 1

Callitriche verna ...... 78

Calluna vulgaris ....... 55

Campanula rotundifolia .. 52

Campion, lied ........ 18

Carnation or Clove.pink.. 17

- Cliamomile............ 51

Chicory.............. 48

Chrysoplenium alternifolium ............ 38

Cichorium Intybus ..... 48

Clematis Vitalba ....... 2

Clove-pink or Carnation.. 17

Clover, Strawberry ...... 28

Codlins and Cream ....... 31

Colchicum autumnale .... 92

Columbine

\section{7}

17

77

100

20

128

129

75

75

95

72

87

88

97

104

45

112

56

86

89

127

15

1] 1

81

77

38

37

77

74

60

74

16

37

49

52

125

20
Fig. Pasce

Convolvulus sepium .... $59 \quad 59$

Convolvulus Soldanella .. $60 \quad 88$

Creeping Cinquefoil ...... $30 \quad 51$

Crithmum maritimum.... $41 \quad 62$

Crowfoot, Bulbous ..... 115

Cuckoo-pint .......... 95129

Daffodil or Daffy-downdiliy ............ $86 \quad 119$

Deadly Nightshade ...... $64 \quad 95$

$\begin{array}{llll}\text { Dianthus Caryophyllus } & . . & 17 & 37\end{array}$

Dipsacus Fullonum ..... $47 \quad 73$

Draba velna .......... $12 \quad 30$

$\begin{array}{llll}\text { Drosera rotundifolia } & \ldots & 16 & 35\end{array}$

Dwale ............. $64 \quad 95$

Dyer's Woad.......... 11 28

Echium vulgare .......61 $61 \quad 89$

Elder................ 4469

Elecampane ......... $50 \quad 76$

Epilobium angustifolium . $31 \quad 52$

Erica tetralix.......... $54 \quad 80$

Eryngium maritimum.... $40 \quad 61$

Euphorbia Peplis ....... $77 \quad 110$

Evening Primrose....... $32 \quad 53$

Flag, Sweet........... $96 \quad 131$

Flag, Yellow or Water .. 85117

Flax .............. $19 \quad 38$

Forget-me-not ....... 6290

Fritillary ............. $90 \quad 123$

Fritillaria Meleagris .... 90123

Fuller's Teasle ........ $47 \quad 73$

Galeopsis Ladanum ...... $69 \quad 103$

Galium verum ........4 $46 \quad 72$

Gentian, Spring........ $57 \quad 85$

Gentiana verna ........ $57 \quad 85$

Geranium sanguineum .. $25 \quad 45$

Germander Speedwell .... $66 \quad 98$

Glaucium luteum $\ldots . . .10 \quad 10 \quad 27$

Glaux maritima........ $71 \quad 105$

Globe Flower......... $5 \quad 19$

Grass of Parnassus ...... $24 \quad 44$

Great Bindweed ....... $59 \quad 87$ 
Fig. Pige

Harebcll

Heath .0 .0 .0 .0 .0 .054

Heather .............. 55

Hclianthemum vulgare .. 14

Hemp Ncttle, Red ..... 69

Henbane ............. 63

Hogsbean ............6. 63

Holly............... 56

Holly, Sea .......... 40

Honeysuckle .......... 45

Houseleek ........... 35

Hyacinth, Grape ....... 88

Hyacinthus noriscriptus . . 87

Hyacinth, Wild ....... 87

Hydrocotyle vulgaris ... 39

Hyoscyamus niger ..... 63

Hypericum calycinum.... 23

Hypericum, Large-flowered 23

Ilex Aquifolium......... 56

Inula Helenium......... 50

Iris pseudacorus ....... 85

Isatis tinctoria ........ 11

Lathyrus aphaca ...... 29

Lavatera arborca ....... 20

Lavatera, Sea......... 20

Lily, Snakeshead ....... 90

Lily, Turk's-cap ....... 91

Lily, White Water....... 8

Lilium Martagon ........ 91

Linum usitatissimum .... 19

Lonicera Periclymenum .. 45

Loose-strife, Creeping.... 73

Lords and Ladies ....... 95

Iysimachia Nummularia . 73

Lythrum Salicaria ...... 33

Mallow, Marslı....... 22

Mallow, Musk ......... 21

Mallow, Trce .......... 20

Malva moschata ....... 21

Marsh Pennywort....... 39

Marsh Saxifrage ....... 36

Marsh Trefoil.......... 58

Meadow Saffron ....... 92

Menyanthes trifoliata.... 58

Misletoe ............ 43

Monkshood .......... 7

Moneywort.......... 73

Mullein, Great ........6 68

Muscari racemosum .... 88

Myosotis palustris ..... 62

Narcissus pseudnnarcissus 86

Nasturtium officinale .... 13

Nymphaca alba ....... 8

Enothera bicnnis ....... 32

Old Man's Beard
Fig. Page

Ononis spinosa ....... 27

Ophrys apifera ........ 83 115

Ophrys muscifera...... 84 117

Orchis, Bee.......... $83 \quad 116$

Orchis, Early......... $81 \quad 113$

Orchis, Fly .......... $84 \quad 117$

Orchis, Man or Military .. $82 \quad 115$

Orchis maccula ........ 81 113

Oxalis acetosella ....... $26 \quad 47$

Papaver Argemone ..... $9 \quad 25$

Parnassia palustris ..... 24 44

Parsnip, Wild .......... 42 64

Pastinaca sativa ...... $42 \quad 64$

Pennywort, Marsh ..... $39 \quad 60$

Pheasant's Eye ......... $4 \quad 18$

Pimpernel ........... it 107

Pimpernel, Bog....... 75108

Plantago major......... $70 \quad 108$

Plantain ............ $76 \quad 108$

Poor Man's weather-glass 74107

Poppy, Prickly ........ 92.5

Poppy, Ycllow Horn...... $10 \quad 27$

Potentilla reptaus $\ldots . . .30 \quad 30$

Prickly Poppy ......... 925

Primrose $\ldots \ldots \ldots \ldots \ldots \ldots$ \%2 10.5

Primula vulgaris ...... $72 \quad 10$.

Purple Loosc-strife ...... 33 5i

Purple Spurge......... $77 \quad 110$

Ranunculıs bulbosus .... , 15

Red Bryony ............ 3t 5ti

Red Crane's-bill........ 25 45

Rest Harrow .......... 27 48

Rock Cist $\ldots \ldots \ldots \ldots \ldots 14 \quad 33$

Rock Rose ........... is 33

Rush, Flowering ...... 93 127

Saffion, Meadow ....... 92125

Sagittaria saynttifolia $\ldots . . .94 \quad 128$

St. John's Wort......... 2343

Sambucus nigra $\ldots . . .44469$

Samphire........... $41 \quad 62$

Saxifraga Hirculus ...... $36 \quad 59$

Saxifrage, Golden ....... $38 \quad 60$

Saxifrage, Marsl $\ldots . \ldots \ldots .36$ ह.

Scilla verna $\ldots \ldots \ldots \ldots .8$ 8. 123

Sea Aster........... \&9 75

Sea Milkwort......... il 105

Sempervivum Tectorum .. $35 \quad 57$

Sium angustifolium ..... $37 \quad 59$

Snake's.head Lily....... gn 123

Snapdragon $\ldots \ldots \ldots \ldots .67 \quad 100$

Solanum Dulcamara $\ldots .65597$

Spurge, Purple ........ $77 \quad 110$

Squill, Spring ......... $89 \quad 12: 3$

Starwort, water ...... is 111

Stratiotes aloides ....... $80 \quad 113$

Strawberry Clover ..... $28 \quad 49$ 


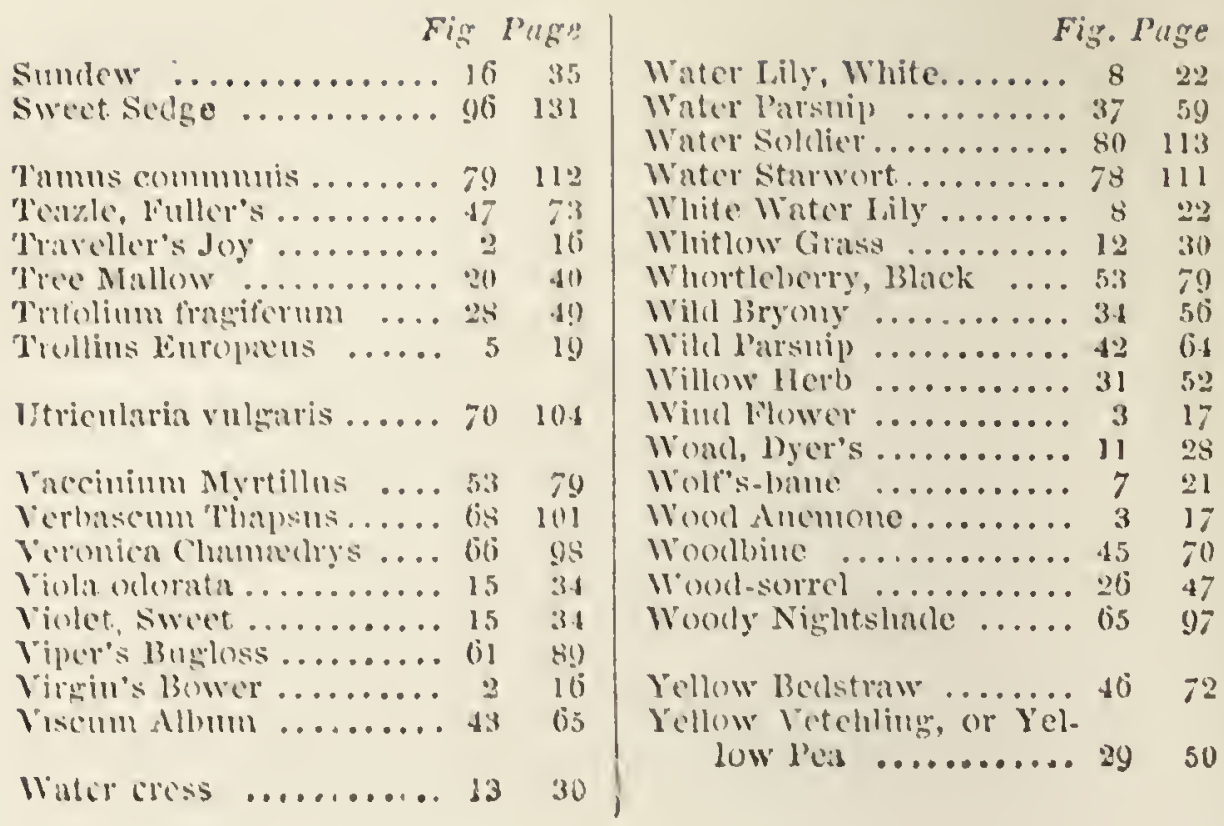

111: END 


\section{SOWERBY'S ENGLISH BOTANY:}

\section{CONTAINING}

Descriptions and Drawings of every British Wild Flower, Life Size

and coloured to Nature by Hand-Painting.

Sciextific Editor-J. T. BOSWELL SYME, F.L.S.

Popular Editor-MrS. LANKESTER.

\section{VOIUME I.}

Contains all the Rues, Anemones, Crowfoots, Spearworts, Waterlilies, Poppies, Fumitories, Mustards, Rockets, Stocks, Lady's Smocks, Cresses, and other Plants ranked under the Natural Orders RANUNCULACEE to Cruciferis.

Seven Parts at 5s. each. Complete in cloth, price, 38s.; in half-morocco, $42 \mathrm{~s}$.; in whole morocco, $48 \mathrm{~s} .6 \mathrm{~d}$.

\section{VOLUME II.}

Contains all the Mignonettes, Rockroses, Pansies, Sundews, Milkworts, Pinks, Catchflies, Campions, Chickweeds, Stitchworts, Sandworts, Pearlworts, Spurreys, Waterworts, St. John's Worts, Mallows, Flayes, Crane's Bills, Geraniums, and other Plants ranked under the Natural Orders RESEDACE

Seven Parts at 5s. Complete in cloth, $38 s . ;$ in half morocco, 42s.; in whole morocco, $48 s$. 6 .

\section{VOT,UME III.}

(Ready August 1st, 1864) will contain all the Furzes, Brooms, Restharrows, Vetches, Lucernes, Medocks, Melilots, Trefoils, Clovers, Wild Plums, Cherries, Apples, Pears, Strawberries, Cinquefoils, Brambles, Wild Roses, and other Plants ranked under the Natural Orders LEGUMINIFERA to ROSACE伥.

Seven Parts at $5 \mathrm{~s}$. Complete in cloth, 38s.; in half-morocco, 42s.; in whole morocco, $48 s .6 \mathrm{~d}$.

The Athencum, in a critical and highly favourable review, says :--

"Mr. Syme's 'English Botany' will be the most complete Flora of Great Britain ever brought out. This great Work will find a place whereever botanical science is cultivated, and the study of our native plants with all their fascinating associations held dear."

The Work commenced in January, 1863, and has appeared regularly. As all the Parts are kept in print Subscribers can commence taking the Work whenever they like.

Anybody desirous of seeing the Work can do so by application to the Publisher, or the Publisher will afford facilities for Booksellers to show it to their customers. 


\section{THE POPULAR SCIENCE REVIEW, A QUARTERLY MISCELLANY}

Of Entertaining \& Instructive Articles on Scientific Subjects.

$$
\text { EDITED BY HENRY LAWSON, M.D., }
$$

Frofessor of Plysiology in Queen's College, Birmingham, and one of the Lecturers on Nutural Srience under the "Science and Art Department of

the Committee of Council on Education."

The Popular Scinnce Revirw is, as its name implics, a Review conveying scientific knowledge in such a simplc and popular form, that all who read may understand. There is at the prescit day a numerous and increasing class of intelligent rcaders who, witlout bcing scientific, are nevertheless greatly interested in scientific progress. They wonld willingly become acquainted with scientific truths, but are too often deterred from the pursuit of such studies by the abstruse or technical language in which thesc truths are conveyed.

In order to mect the requircments of this purtion of the community, every available means has becn adopted to procure the most accurate information on all subjects of which the journal treats. No pains or expense has becn spared to sccure the most skilful artists to illustrate its pages.

Each number contains systcmatic, instructive articles illustrated when recedful) on subjects connccted with some of the following aciences, viz.,
ASTRONOMY,
BOTANY,
CinMISTRY,
ETHNOLOGY,
GHOGRAPHY,
GEOLOGY,
Metallurgy,
Microscopy,
Mineralogy,
PHYSICS,
ZOOLOGY,
\&c. \&c., and

SCIENCE applied to the Arts, Mannfactures, Commerce, and Agriculture.

\section{CONTRIBUTORS.}

AnnREws, W., M.R.I.A. (V.-P. of the
Zoolocical Society of Ireland). Gosse, Philip H., F.R.S.

Zoological Society of Ireland).
ANSTED, Professor, F.R.S., F.G.S.

Bond, Prof. F., M.B., F.C.S. (Hartley Institutc, Southampton).

BREEN, JAMES, F.R.A.S.

BUCKLAND, F., F.Z.S.

Buckman, Prof. James, F.L.S., F.G.S.

Coluingwool, C., M.A., M.B., F.L.S.

Cоокк, M. C.

Coultas, Harlani).

CroOkes, William, F.R.S.

De: Quatrefagles, Professor.

Fairbairn, W., LL.D., F.R.S.

Frasir, W., M.D., F.L.S.

Goles, Gronge.

HOGG, JABEZ, M.R.C.S., F.L.S., \&.c. HoughtoN, Rev. W., F.L.S.

HUNT, ROBKRT, F.R.S.

JESSE, E., F.L.S.

Jones, Prof. RYMer, F.R.S.

KInG, Prof. (Quecn's Coll., Galway) LANKESTER, E., M.D., F.R.S., \&c.

LANKESTER, Mrs.

Lewes, George H.

Plues, Miss M.

Phipson, J., M.B., Pr.D., F.C.S.

Stemann, B., Pil.D., F.L.S., \&c.

Tuson, Prof., F.C.S. (Royal Vet. Col.).

VOELCKRR, Prof., F.C.S. (Agriculturai

Coll., Cirencester).

And other Writcrs who take a prominent part in Scicntific Literature.

"This is a wonderful half-crown's worth; its text, as well as its cxcellent and accurate illustrations, show it to bc one of our cheapest and best periodicals. In this its second, as in its first number, it is fully up to. the very highest standard fixed by its conductors. We wish it cvery success, and we heartily commend it to such of our rearlers as takc an intcrest in the various phases of popnlar science."-Standard.

The "Popular Science Review" appears in October, January, April, and July, price Half-a-Crown. Price to Subscribers, 10s. per Annum, Carriage Free. 


\section{ROBERT HA R D I C E E, 192, PICCADILLY, W.}

\section{POPULAR AND SCIENTIFIC WORKS.}

Astronomy, Geology, Palæontology, Zoology, \&c.

Science and Practice of Farm Cultira-

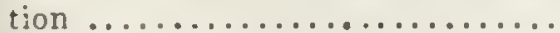
Half-hours with the Microscope .... Mounting Microscopic Objects...... Professor Ansted's Applications of Geologe to Arts and Manufactures Old Bones, a Manual of Palæontolog? British Beetles, by W. H. Groser .. British Land and Freshwater Shells, by R. Tate.................. British Reptiles, by M. C. Cooke.... Our Common Insects, by Mrs. Cox.. Pennell's "Book of the Pike" ...... Ray Societ Publications ........ 10 Chemistre, br Brande and Tarlor .. II Astronomical Observer .......... 11 Fossil Sponges, by Mackie.......... 11 Metamorphoses of Man and of the Lower Animals, from the French of De Quatrefages............. 12 Huxley's Lectures on Origin of Species 12 Hints on the Formation of Local Museums................. 12 The Tannin Process, by C. Russell.. 12 Dry Processes in Photography ..... 13 Petroleum and its Products ....... 13
Picturesque Garden Plans, 24 Coloured Plates ................ 13 Seren Essars on Unirersal Science.. 13

Botany.

Sorerby's English Botany........ 3

- Grassez of (ireat Britain .. 4

Ferns, British and Foreign, by John

Smith .................. --, Srnopsis Filicum, by Sir VI.

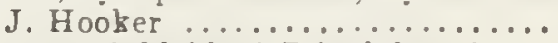
Botany, Schleiden's Principles of .... - A Manual of Structural...... 5 Butanic Terms, Manual of ......... 5 Ferns, a Plain and Easy Account of,

hF Mrs. Lankester ........... 5 --, Album for Dried Specimens .. 5 Sowerby's Useful Plarts......... 5 Fungi, the British.............. 6 —_, Microscopic............ 6 Fungorum Index Britannicorum .... 6 Water Weeds or Algx. by Dr. Grap.. 5 Wild Flowers Worth Notice...... 7 Botany, Monthly Joumal of ....... 11

\section{Publications of Ray Society. (See page in.) \\ $A$ detailed Catalogue on application.}

\section{DOMESTIC, HYGIENIC, MEDICAL.}

Australia for the Consumptire Inralid 13 Popular Ph șiologg (Illustrated) .... 14 First Help in Accidents (Illustrated) 14 Dr. Lankester on Food .......... 14 on the Uses of Animals 15 A Popular History of the Toilet and Cosmetic Arts ............... 15 The Home Nurse, a Manual for the Sick Room .................. 15 Influence of Railway Travelling on Health.................. 16 Lectures on Public Health........ 16 Domestic Management of Infants... 16 Diet of Infancy and Childhood ...... 16 Common Sense of Waier Cure ...... I 6
Gastric Regions and Victualling Department................. 17 Report of the Meeting of the British Association, $1865 \ldots \ldots \ldots \ldots . . .17$ Arcus Senilis, or Fatty Dezeneracy of the Eye, by E. Canton......... 17 Bathing: How to do it ........... 17 Solly on the Human Brain........ 18 Scarlatina and its Treatment, by Isaac

Baker Brown ............... 18 Foot and its Corering........... 18 The Ophthalmoscope, from the German of Zander ............. 18 Gamgee on the Cattle Plague ..... 27 


\section{PEERAGE, COUNTY FAMILIES, \& GENEALOGICAL WORKS.}

Walford's - County Families of the

United Kingdom ............. 19

Hardwicke's Crown Peernge ....... T9

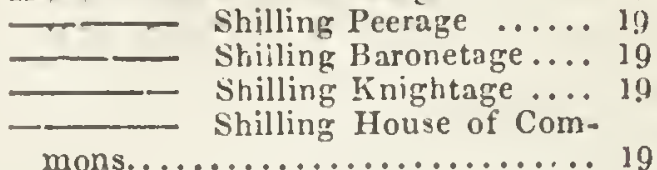

Index to the Pedigrees contained in the printed Heralus' Visitation.... 10

How to address 'Titled People ..... 20

A Corner of Kent-Ash next Sandwich, by J. R. Planehé (lilustrated) 20

Pursuivant of Arms, or Heraldry founded on fact (Illustrated) ..... 20

Enshrined Hearts of IVarriors and Illustrious Peoplc............ 20

\section{FLEMENTARY WORKS.}

Elements of Arithmetic, from the French of Briot..............21 Mangnall's Questions, complete (1s.) 21 Inventive Drawing, by E. Ball ..... 21 How to 'Teach Plain Needlework.... 21

\section{Hardwicke's Zullementary Books.}

Chemistry (6d.)............... 22 Mechanies (4d.) .............. 22 Hydrostaties (2d.) ............. 22 Hydraulics (2d.) ................ 22
Opties (4d.) $\ldots \ldots \ldots \ldots \ldots \ldots \ldots \ldots . \ldots \ldots$ Pneumatics (2d.) ............. 22

\section{Mackenzie's Fducational Books.}

Mackenzie's Tables (2d.) ........ 23 Murray's Grammar (2l.) ......... 23 Walkinghame's Arithmetic (4d.) .... 23 Book-keeping by Single Entry (2ả.) 23 Mavor's Spelling (4d.).......... 23 Shorthand $(2 d.) \ldots \ldots \ldots \ldots \ldots \ldots . . . . .23$ Phrenology (2d.) .............. 23 Manual of Gcography (6d.) ...... 23

\section{CELLAN刃OUS.}

Srience and Practice in Farm Cultivation. IBy Prof. Buckman ...... \&

Holiday Papers, by Harsy Jones .... 23 Dr. Wynter's Curiosities of Civilization .................... 24 $\longrightarrow$ Our Social Bees ...... 24 Subtle Brains and Lis. som Fingers ................ 25 The Stream of Life on our Globe, by J. L. Milton ................. 25 Country Cottages, with Plans, Elevations, \&e., by J. Vineent ....... 25

History of the British Dog........ 26 Treatise on Smoky Chimneys, by F. Edwards, Jun...............26 On Domestie Fireplaces.......... 26 Fry's Shilling Charities, of London ........................ 26
Hardwicke's. Handybook of London (Illustrated) .............. 27 Horse Warranty, by P. Howden. . . . 27 Graceful Riding, by S. C. Waite .... 27 Waste Products and Substances, by P. L. Simmonds ..............27 On Whist, by Cœlebs ........... 28 One Hundred Double Acrostics .... 28 Alexander von Humboldt ......... 28 Autobiography of a Working Man .. 28 Perer Sehlenihl, Illustrated by Cruikshank ................. 28 On Wines, by J. R. Sheen........ 28 Shooting Simplified, by J. D. Nougall 28 Kcnnard's Essays and Reviews...... 29 'The 'Iramp's Wallet, a. Tour on the Continent................. 29
Sowerby's English Botany.(Monthly) 3 Journal of Botany (Monthly)....... 11
Science Gossip (Monthly.) .........29 29 Popular Science Review.(Quarterly).. 30 


\section{Sowerby's English Botany :}

Containing a Description and Life-Size Drawing of every British Plant. Edited and brought up to the present standard of scientific knowledge by T. Boswell Syme, F.L.S., \&c. With Popular Descriptions of the Uses, History, and Traditions of each Plant, by Mrs. Lankester, Author of "Wild Flowers worth Notice," "The British Ferns," \&c. The Figures by J. E. Sowerby, James Sowerby, F.L.S., J. de C. SowerbY, F.L.S., and J. W. SAlter, A.L.S.

\section{The Distinctive Characteristics of this cdition are,-}

1. A life-size drawing of every British plant, arranged according to the Natural System of De Candolle.

2. Where necessary, the plates are accompanied by illustrations of the structure of the various organs of the plant, especially of those structures discovered within the last few years by the use of the microscope.

3. All the illustrations are full-coloured, instead of half-coloured, and the utmost care is taken to adhere as closely as possible to nature.

"Under the editorship of T. Boswell Syme, F.L.S., assisted hy Mrs. Lankester, whose work on 'Wildflowers wurth Notice' is so well appreciated by the public, we have the best guaruntee that 'Sowcrhy's Engiish Botany, when finished, will be exhaustive of the suhject, and worthy of the branch of science it illustrates. . In turning over the charmingly executed hand-coloured plates of British plants which encumber these volumes with riehes, the reader cannot help being struck with the beauty of many of the bunblest fluwering weeds we tread on with carcless step. Our fields, woons, and hillsides, are paved with riches we all too much ncglect.

We cannot dwell upon many of the individuals gsoupea in the splendid houquet of flowers presented in the:e pages, and it will bc suficient to state that rhe work is pledged to contain a figure of every wild flower indigenous to these isles." - The Times, Nov. 3, 1865.

"Will be the most complete Flora of Great Britain ever brought out. This great work will find a place wherever botanical science is eultivated, and the study of our native plants, with all their taseinating associations, held dear." - Athencum.

"Nothing can excred the beauty and aecuraey of the coloured figures. They are drawn life.size-an advantage which every young amateur will recognize who has vainly puzzled over druwings in which a celandine is as big as a poppy-thry are enriched with delicate delineations of print, petal, anther, and any organ whieh happeus to be remarkable in is form-and not a few plates are altogether new. . . . . A clear, bold, distinctive type enables the reader to take in at a glance the arrangement and divisions of every page. And Mrs. Lankester has added to the technical descriptiou by the editor, an extremely interesting popular sketch, which folluws in smaller type. 'The English. French and German popular names are given, and, wherever that delicate and difficult step is at all practicable, their derivation also. Medical properties, superstitions, and fancies, and poetic rributes and illusions follow. In short, there is nothing inore left to be desired." - Guardiun.

"Should the succeeding parts be as good, the work, when eomplete, will be without a rival in exeellence." - Observer.

"Without question, this is the standard work on Botany, and indispensable to every botanist. - . The plates are most aceurate and beautiful, and the entire work cannothe ton strongly reeulanended to all who are interested in Botuny." -Illustrated London News. 
Demy 8vo. price 10s. 6d. Hurdreds of Wondcuts, and 6 pages of Figures beautifully engraved on Stcel.

\section{Schleiden's Principles of Scientific Botany;}

or, Botany as an Inductive Science. Translated by Dr. LANkester.

Every Botanical Library should possess this Work, as it contains the principles upon which all structural botany is based.

Crown 8vo. cloth, fully Illustrated, price 6 .

\section{Ferns, British and Foreign.}

Their History, Organography, Classification, Nomenclature, and Culture, with Directions showing which are the best adapted for the Hothouse, Greenhouse, Open-Air Fernery, or Wardian Case. With an Index of Genera, Species, and Synonyms. By John Sмrтн, A.L.S., late Curator of the Royal Gardens, Kew. With nearly 200 Woodcuts.

Mr. Smith is acknowledged to be one of the first authorities on Ferns, having been engaged nearly half a century in arranging them at Kew.

In 9 Parts, at 2s. each plain; $2 s$. 6d. coloured.

\section{Synopsis Filicum ;}

A Synopsis of all Known Ferns. With about 100 Figures of Genera, beautifully Drawn on Stone by Fiтcн.

Royal 8vo. cloth, price £1. $14 s$.

\section{The Grasses of Great Britain,}

Containing life-sized, full-coloured Drawings, with magnified Organs, of 144 British Grasses, and Observations on their Natural History and Uses. Described by Charles Johnsox. Illutrated by J. E. Sowerby.

This is the most comprehensive Work on British Grasses, and is the only book which gives the magnified organ to cnable the reader to recognize the various grasses.

Complete in One Volume, cloth, $7 s .6 d$.

\section{Science and Practice in Farm Cul- tivation.}

By Professor Buckman, F.L.S., F.G.S.-1. How to Grow Good Root Crops. 2. How to Grow Good Grass Crops. 3. How to Grow Good Clover Crops. 4. How to Grow Good Corn Crops. 5. How to Grow Good Hedges. 6. How to Grow Good Timber. 7. How to Grow Good Orchards. Fully Illustrated. 
Beautifully bound, bevilled edges, price $12 s$.

\section{The Useful Plants of Great Britain.}

A Treatise on the Principal Native Vegetables capable of Application as Food or Medicine, or in the Arts and Manufactures. By C. P. Johnson. Illustrated by J. E. SowerbY. 300 Illustrations coloured by hand.

Illustrated by more than 200 Woodcuts, price $1 s . ;$ bound, 1s. 6d.

\section{A Manual of Structural Botany.}

By M. C. Cooke, Author of "Seven Sisters of Sleep," \&e.

"Condensed yet clear, comprehensive but brief, it affords to the learner a distinct view."-Globe.

"We are confidently able to recommend the little volume to public favour, its very low price (is.) bringing it within the range of all purchasers." $-E v a$.

Fcap. 8vo. cloth, price 2s.6d.

\section{A Manual of Botanic 'Terms.}

By M. C. СоoкE. With more than 300 Illustrations.

"We do not hesitate to say that by a careful use of this book a sound knowledge of the theoretical portion of Botany may be obtained without tedious labour."-Mining Journal.

Handsomely bound, price One Guinea. A Large Edition, without descriptive letter-press, One Guinea.

\section{'The Fern Collector's Album.}

A Descriptive Folio for the reception of Natural Specimens; containing on the right-hand page a description of each fern printed in colours, the opposite page being left blank, for the collector to affix the dried specimen; forming, when filled, an elegant and complete collection of this interesting family of plants.

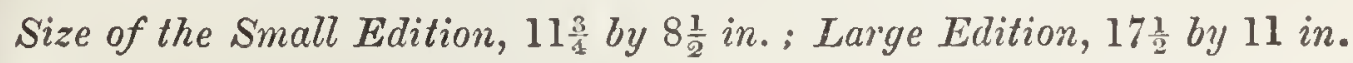

Fully illustrated, price $4 s$. coloured by hand; $2 s$. 6d. plain.

\section{The British Ferns}

(A plain and Easy Account of). Together with their Classification, Arrangement of Genera, Structure, and Functions, Directions for Out-door and In-door Cultivation, \&c. By Mrs. Lankester.

"Not only piain and easy, but elegantly illustrated."-Athencum.

"Mrs. Lankester has given us a handy pocket volume, with a great deal of information about the uses, supposed and real, of the Ferns, and hints for their cultivation."-Guardian. 
Fcap. 8vo. price $6 s$.

\section{The British Fungi}

(A plain and Easy Account of). With especial reference to the Esculent and other Economic Species. By M. C. Cooke. With Coloured Plates of 40 Species.

"The author is a thorough mycophagist, well acquainted with the peculiar features by which the most remarkable of the edible kinds of Fungi may be known."Gardener's Chronicle.

"A very rcadable volume upnn the lowest and least generally understood race of plants. For popular purposes the book could not have been better done."-Athenoum.

Royal 8vo. price $2 s .6 d$.

\section{Index Fungorum Britannicorum.}

A complete List of Fungi found in the British Islands to the Present Date. Arranged so as to be applicable either as a checklist or for Herbarium Labels. By M. C. Cooke.

Also the same Work printed on only one side.

Part I. Hymenomycetes, $1 s$. Part II. Gastromycetes, Coniomycetes, and Hyphomycetes, 1s. Part III. AscomyCETES, 1 s.

Croun 8vo. clotihn, $3 s .6 d$.

\section{Handbook of British Water-weeds, or Algæ.}

By John Enward Gray, F.R.S., late President of the Botanical Society of London. The Diotomaces, by W. Carruthers.

Fcap. 8vo. nearly 300 coloured Figures, price $6 s$.

\section{Rust, Smut, Mildew, and Mould.}

An Introduction to the Study of Microscopic Fungi. By M. C. Cooke, Author of the "British Fungi."

"There is a thoroughness about Mr. Cooke's writings which always makes his communications welcome. He is not content to gather information from cyclopæedias, classify and adapt the same, and then givc a new form to the thoughts of others. On the contrary, lse strikes out a new course of study, and after a laborious course of analysis, produces an entirely original work, one on which nothing of the kind had been before attempted."-Wesleyan Times. 
Fcap. 8vo. cloth, coloured by hand, 4 s.

\section{Wild Flowers worth Notice.}

A selection from the British Flora of some of our native plants which are most attractive for their Beauty, Uses, or Associations. By Mrs. Lankester. Illustrated by J. E. Sowerby.

"We could while away a long summer day talking of the plcasant things suggested by this littlc book. Although all intelligent persons cannot become botanists, not to know the wild flowers of our eountry is to be ignorant both of our country and ourselves. And this little book will, as a pocket companion during holiday ramblesthe descriptions and plates being both good-destroy this ignorance in reference to at least a hundred plants. After mastering it, the student will be not a little astounded at his own learning, when he surveys it in the systematic chapter of eontents." Athencum.

Third Edition, much enlarged, with full description of the various parts of the Instrument, price $2 s$. $6 d$. plain; $4 s$. coloured.

\section{Half-hours with the Microscope.}

By EDwin LANkester, M.D. Illustrated by 250 Drawings from Nature by Tuffen West.

\section{CONTENTS.}

Half-an-hour on Structure.

Half-an-hour in the Garden.

Half-an-hour in the Country.

Half-an-hour at the Pond'-side. Half-an-hour at the Seaside.

Half-an-hour In-doors.

Appendix.-The Preparation and Mounting of Objects.

"The beautiful little volume before us cannot be otherwise than welcome. It is, in fact, a very complete manual for the amateur microsconist . . . . The "HalfHours' are filled with clear and agreeable dcscriptions, whilst eight plates, exccuted with the most beautiful minuteness and sharpness, exhibit no less than 250 objects with the utmost attainable distinetness." - Critic.

Fcap. cloth, price $2 s .6 d$.

\section{The Preparation and Mounting of Microscopic Objects.}

By Thomas Davies.

This Manual comprises all the most approved methods of mounting, together with the result of the Author's experience and that of many of his friends in every department of Mieroscopie Manipulation; and as it is intended to assist the beginner as well as the advanced student, the very rudiments of the art have not been omitted.

Ciar. I.-Apparatus. II.-To Prepare and Mount Objeets Dry. III.-Mounting in Carada Balsam. IV.- Preservative Liquids. V.-Sections, and How to Cut them, with Femarks on Dissection. VI.-Injection. VII.-Miseellaneous.

"Nothing is more diffieult to those who handle a microseope for the first time than to get their objects in a fit state for exhibition and preparation. They will therefore feel greatly indebted to Mr. Davies for a little book on "The Preparation and Mounting of Microseopie Objeets.' It is clcar, full, and practieal ; and if it is a little alarming at first sight by the quantity of apparatus applied in it, it soon reveals to the eareful student the valuable faet that a great deal may be done with very simple appliances. We recommend it to young mieroseopists as a book which supplies a fult deficiency."-Guardian. 


\section{The Applications of Geology to the Arts and Manufactures.}

Six Lectures delivered before the Society of Arts. By Professor D. T. Ansted, M.A., F.R.S.

I.-On the Formation of Natural Soils by Derivation from Rocks, and on the Improvement of Soils by the admixture of Minerals.

II.-On Natural and Artificial Springs, and on the various Sources of Water Supply for Towns and Cities, in connection with the Geological Structure of the Vicinity.

III.-On Mineral Materials used for the Purposes of Construction: Plastic and Incoherent Materials (Clays and Sands).

IV.-On Mineral Materials (continued) : Building Stones and Slates, and their Relative Value under given Circumstances of Exposure, and on Methods of Quarrying.

V.-On Stratified Deposits of Minerals, as Coal and Iron Ore, usually obtained by Mining Operations, and on Mining Methods for such Deposits.

VI.-On Metalliferous Veins for Lodes and their Contents, and on the Extraction of Metalliferous Minerals from Lodes.

"The scicnce of geology largely engages the attention of the public; but persons are frequently deterred from the study of it hy the dry and tedious style of writers dedicating their talent to its exposition. Professor Ansted has supplied a book which meets the public want. . . Those relating to agricultural geology have an especial interest for farmers; but the whole are deeply interesting and worthy of recommendation." - News of the World.

"Professor Ansted takes in hand a subject of some difficulty, but of universal importance. In this he describes the different kinds of mineral veins, their contents, and the methods adopted to extract those coritents, and thus fitly concludes his lahours in elucidation of the practical application of geological knowledge to economic purposes, especially in connexion with the arts." -Daily News.

Second Edition, much improved and enlarged. With references to the typical specimens in the British Museum. Fcap. Svo. price $2 s .6 d$. Fully illustrated.

\section{Old Bones ; or, Notes for Young Naturalists.}

By the Rev. W. S. Srmonds, Rector of Pendock, Author of "Stones of the Valley," \&c.

"The plan pursued by Mr. Symonds is a very simple one. He adopts the classification of Professor Owen, and carries the young naturalist from family to family, beginning with man and ending with the lowest fishes, making his own remarks as he goes on. We recommend these notes. The volume is neatly got up, and deserves a sale amongst the class for whom it is intended."-Athenaum. 
Fcap. 8vo. cloth, 4s.plain; 6s. coloured. Fulty Itlusirated.

\section{The British Reptiles}

A Plain and Easy Account of the Lizards, Snakes, Newts, Toads, Frogs, and Tortoises, indigenous to Great Britain. By M. C. Cooke, Author of "The British Fungi," \&c.

Fcap. 8vo. cloth, 4s. plain; 6s. coloured. Fully Iilustrated.

\section{Slugs and Snails, Land and Fresh- Water,}

A Plain and Easy Account of the Land and Fresh-water Mollusks of Great Britain. Containing Descriptions, Figures, and a Familiar Account of the Habits of each Spccies. By Ralph Tate, F.R.G.S.

Fcap. Svo. ctoth, 4s. plain; 6s. coloured. Fully Illustrated.

\section{The British Beetles}

(A Plain and Easy Account of). By W. H. Groser, B.S.

In preparation.

Fcap 8vo. cloth, price 2s. $6 d$.

\section{Our Common Insects.}

First Steps to Entomology. By Mrs. E. W. Cox.

Croun 8vo., price 5s., illustrated,

\section{The Book of the Pike.}

A Practical Treatise on the various methods of Jack Fishing, with an analysis of the Tackle employed, the History of the Fish, \&c. Also a Chapter on Spinning for Trout in Lakes and Rivers. By H.Cholmondeley-Pennell, Author of "The Angler Naturalist." 


\section{PUBLICATIONS OF THE RAY SOCIETY.}

British Hemiptera-Heteroptera.

By J. W. Douglas and John Scotr. 21.10 s.

Cirripedia Family.

By C. DARWIN, Esq. 2 vols. £2. 2s.

British Freshwater Polyzoa.

By Professor Allman. $\mathscr{E} 1.11 \mathrm{~s} .6 \mathrm{~d}$.

Recent Foraminifera.

By Professor Williamson. $\mathscr{E} 1.11$ s. $6 \mathrm{~d}$.

Oceanic Hydrozoa.

By Professor H UxLEY, £1.118. 6d.

Organization of Trilobites.

From the German of Burmpister. 15s.

British Naked-eyed Pulmograde Medusæ.

By Professor E. Forbes. $\mathcal{L}_{1 \mathrm{~s} .1 \mathrm{~s} .}$

The Spiders of Great Britain and Treland.

By J. BraCKWalz, F.L.S. 2 vols, 23.13 s. 6 d.

Foraminifera.

By Dr. Carpenter. $\mathscr{L} 1.118 .6$ d.

Fructification of Higher Cryptogamia, and Coniferæ.

From the German of HOFXEISTRR. $21.5 \mathrm{~s} .6 \mathrm{~d}$.

Reptiles of India.

By Dr. Guntine. $\quad \mathscr{E 2 . 2 3 .}$

British Spongiadx.

By Dr. BowERBANK. Vol. 1. 21.10 s.

Steenstrup on Alternation of Generations. $15 \mathrm{~s}$.

British Entomostracous Crustacea.

By Dr. BAIRD. $\mathscr{1} 1.18$.

British Angiocarpous Lichens.

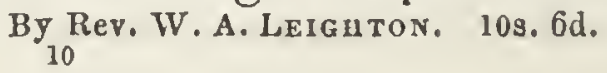


Fcap. 8 vo. cloth, 900 pages, price 12 s. 6 d.

\section{Chemistry.}

By Professor Brande, D.C.L., F.R.S.L., and Professor Alfred

S. TAYLoR, M.D., F.R.S., F.R.C.P., LonJ.

"For clearness of language, accuracy of description, extent of information, and freedom from the pedantry and mystıcism of modern Chemistry, no other text-book comes into competition with it. . The best guide to the study of Chemistry yet given to the world."-Lancet.

"Conceived and worked out in the most sturdy common-sense method, this book gives, in the clearest and most sumnary metliod possible, all the facts and doctrines of Chenistry, with more especial reference to the wants of the Medical Student." Medicul Times.

Bound in cloth, price \&1.5s. each, beautifully Illustraled by Fitch, Volumes I., II., and III. of the

\section{Journal of Botany, British and Foreign.}

Edited by Berthold Seemany, Ph.D., F.L.S., F.R.G.S.

The Journal consists of two distinct sections: the one devoted to General Botany, the other to the Botany of the British Isles. In both divisions Original Papers on subjects new to Science are given, and when necessary, illustrated either in the Text, or by special Plates.

The "Jounnal of Botany" is published on the lst of every Month, price 2s. Annual Subscription, $£ 1$. 1s., post-free.

Price 7s. 6d., Royal 8vo. cloth.

\section{The Astronomical Observer;}

A Hand-book for the Observatory and the Common Telescope. By W. A. Darby, M.A., F.R.A.S., Rector of St. Luke's, Manchester. Embraces 965 Nebulæ, Clusters, and Double Stars.

"I think the design of the work has been well carried out. The Catalogue will no doubt he very acceptable to the amateur ubserver desirous of obtaining a knowledge of practical Astronomy, and it will also be useful in the library of the regular Observatory."-From the Eurl of Rosse, K.P., F.R.S., \&c.

In 5 Parts at 5 s. each.

\section{The British Fossil Sponges}

(An Illustrated Catalogue of). With Description and Figares of upwards of 200 Typical Specimens. By S. J. MACKı. 


\section{Metamorphoses of Man and Animals.}

Describing the changes which Mammals, Batrachians, Insects, Myriapods, Crustacea, Annelids, and Zoophytes undergo whilst in the egg; also the series of Metamorphoses which these beings are subject to in After-life. Alternate Generation, Parthenogenesis, and General Reproduction treated in extenso. With Notes, giving references to the works of Naturalists who have written upon the subject. By A. De Quatrefages. Translated by Henry Lawson, M.D.

"We have already said enough to show that the essay which Dr. Lawson has introduced to $u$ s in an Englieh garb is one which marks a new era in the history of Embryology, and which presents to both general and scientific seaders information which has been hitherto confined to the realms of dusty periodicals of all languages. 'The Metamorphoses' is a work which tends to elevate the science of Biology, and deserves the attention of all classes of cultivated readers." -London Review.

Complete in cloth, price $2 s .6 d$.

\section{Prof. Huxley's Lectures "On the Origin of Species."}

1. The Present Condition of Organic Nature.-2. The Past Condition of Organic Nature.-3. The Method by which the Causes of the Present and Past Conditions of Organic Nature are to be discovered. The Origination of Living Beings.-4. The Perpetuation of Living Beings, Hereditary Transmission, and Variation. -5. The Condition of Existence as affecting the Perpetuation of Living Beings.-6. A Critical Examination of the Position of Mr. Darwin's Work "On the Origin of Species," in relation to the complete Theory of the Causes or the Phenomena of Organic Nature.

"Readers who cannot accept Mr. Darwin's doctrines and conclusions will still be relighted with these lectures, since they embody so much curious information and so many important principles of biological scienee, expressed so clearly as to render the book, even to readers possessing scarcely any previous knowledge of the subject, not only intelligible but more interesting than any romance."-Weldon's Register.

\section{Hints on the Formation of Local Museums.}

By the Treasurer of the Wimbledon Museum Committee.

Second Edition, with Appendix, Fcap. cloth, price 2s. 6 d. The Tannin Process. By c. Russeru. 
Post 8vo. price 2s.

\section{A Description of certain Dry Pro- cesses in Photography.}

Specially adapted to the use of the Tourist; with Supplementary Notice of Plans, useful to the Scientific Traveller and Missionary. By George Kemp, M.D., St. Peter's Coll., Cambridge, Fellow of the Cambridge Philosophical Society.

Post 8vo. price 2s. 6d.

\section{Petroleum and its Products.}

An Account of the History, Origin, Composition, Properties, Uses, and Commercial Value of Petroleum; the Methods employed in Refining it, and the Properties, Uses, \&c., of its Products. By A. Norman Tate, F.C.S., Analytical Chemist, Hon. Sec. to the Liverpool Chemists' Association.

Fcap. Folio, cloth, with 24 Coloured Plans, price 21s.

\section{Picturesque Garden Plans.}

A Practical Guide to the Laying-out, Ornamentation, and Arrangement of Villa Gardens, Town Squares, and Open Spaces, from a quarter of an acre to four acres; for the use of practical Gardeners, Architects, Builders, and Amateurs. By R. Siевеск, Superintendent of Public Gardens, Vienna. Adapted to English Gardens, \&c., by Joseph Newton, F.R.H.S.

"The arrangement is concise and completely descriptive, so that any expert gardener can, by a very short study of the examples set forth, arrange or adorn large or small plots encircling new abodes, on naked down or barren waste."-Builder.

Crown 8vo., 5 s.

\section{Australia for the \\ Consumptive} Invalid.

The Voyage, Climates, and Prospects for Residence. By I. BAKEr Brown, Jun.

Price 7s., handsomely bound in cloth; or, in separate Essays, 1 s. each, a Series of

\section{Seven Essays on Universal Science.}

Embracing some Investigations of the Mosaic Cosmogony, and the Interpretations of the Scriptures, with the object of Proving their Scientific Exactness. By Thomas Clark Westfield, F.S.A. 
Fcap. 8vo., with Ninety Illustralions, price 2s. 6 d.

\section{A Manual of Popular Physiology :}

Being an Attempt to Explain the Science of Life in Untechnieal Lanouage. By Henry Lawson, M.D., Co-Lecturero on Physiology and Histological Anatomy in St. Mary's Hosp.tal Medical School.

"Dr. Lawson has succeded in rendcring his manual amusing as well as instructive. All the great facts in human vhysi, logy are presented to the rrader successively; and ether for privare reading or for classes, this manual will be found well adapted for initiating the uninformed into the mysteries of the structure and functions of their own booies."-Aticencelm.

In Sup. Royal 32mo. cloth, price $2 s .6 d$.

\section{First Help in Accidents.}

Being a Surgical Guide in the absence or before the arrival of Medical Assistanee. For the use of the Public, especially for Members of both Military and Naval Services, Volunteers, and Travellers. By Charles H. Schaible, M.D., Ph.D., Royal Military Academy, Woolwieh. Fully lllustrated.

\begin{tabular}{l|l|l|l} 
Bites & Burns & Drowning & Scalds \\
Bleeding & Choling & Exhaustion & Splains \\
Broken Bones & Cold & Hanging & Suffocation \\
Bruises & Dislocations & Poisoning &
\end{tabular}

And other Accidents where instant aid is needful.

"A most useful and interesting litıle hook, which is, besides, prettily got up, and contains some accurate and nice woodcuts. In 200 small pages we find, condensed, wharcuer can be done in case of accioients until the arrival of a professional helper; in fact, the work is a short but complete marual, and will prove of great service to military men, volunteers, and tourists. * * * The instructions are plain and to the point, and there is a welcome absencc of technical terms." - Spectutor.

$400 \mathrm{pp} .$, Crown Svo. cloth, fuliy illustrated, price $3 \mathrm{~s}$.

\section{Dr. Lankester on Food.}

A Course of Leetures delivered at the South Kensington Museum. By E. Lankester, M.D., F.R.S., F.L.S.

WATER.

SALT.

Heat-givers - Oil, Butter, FAT.

Flesh-formers-Animal Food.
Alcohol.

Wines, Spirits, and Beer. Condiments and Spices. Tea, Coffee, and Chocolate. Tobacco and OpIum.

"Full of sound science, curious anecdote, and quaint illustration. Dr. Lankester has a singular power of illustrative keenviess; and in the discursive lessons which he delivers in so many subjects, there is an overflowing wealth of mitute collateral information which is always.brought to the level of the last achieveurenis of science." Luncet. 
$350 \mathrm{pp}$. Crown 8vo., cloth, fully illustrated, price $3 s$.

\section{Dr. Lankester on the Uses of Animals}

In Relation to the Industry of Man. By Edwin Lankester, M.D., F.R.S. A Course of Six Lectures, delivered at the South Kensington Muscum.

SiLK.

Wool.

Leather.

BONE.

SonP.

WASTE.
Sponges and Corals.

SHELL.FISH.

INSECTS.

Furs.

Fentirers, Horns, and Harr.

Animal Perfumes.

"The information is presented in the most lucid, graceful, and entertaining manner."-Economist.

"Every one who peruses them will be grateful to the author. The history of those creatures whose products become through man's skill so useful to him, is given with such charming teeling, that the interest of the reader is attracted and enchained, whether he wills or no." - Era.

In 1 vol. Crown 8vo. cloth, price $5 s$.

\section{Dr. Lankester on Food and on the Uses of Animals.}

Crown 8vo., price 10 s.

\section{A Popular History of the Toilet and Cosmetic Arts}

In Ancient and Modern Times; with a Notice of the Diferent Theories of Beauty, and allied Information, Social, Hygiznic, sist Medical, including Instructions and Cautions respecting the selection and use of Perfumes, Cosmetics, and other Toilet Arricles, and very copious Furmula for their Preparation. By A.J. Cooley, Author of "The Dictionary of Practical Receipts," \&c.

Second Edilion, Fcap. 8vo. cloth, price 2s. 6d.

\section{The Home Nurse.}

A Manual for the Sick Room. By Estrer Lr Hardy.

"In our notice of the first edition, we expressed our apvrobation of the manner in which she had performed her task; and we are gratified to see that the useful lessons she inculeated both in regard 10 nursing and nodical attendanee have met with such general approval as to require anotber edition of her unpretending but really valuable volune."-Lancet. 
Fcap. 8vo. cloth, price 1 s.

\section{The Influence of Railway Travel- ling on Public Health.}

From the Lancet.

"We strongly recommend the work to all who are connected with the managcment of railways, or in the habit of travelling by them. The mass of evidence goes to prove that whilst the actual danger of life in travelling by rail is comparatively small, that to health is, from various causes, considerablc. But for the discussion of these and thcir remedies, wc must refer the reader to the book itself." - Dispatch.

\section{Fcap. 8vo. sewed, 2s. 6d.}

\section{Lectures on Public Health,}

Delivered at the Royal College of Surgeons. By E. D. Mapother, M.D.

\section{The Domestic Management of Infants and Children,}

In Health and Sickness. By S. BARKer, M.D.

Demy 8vo. sewed, price ]s.

\section{The Diet of Infancy and Childhood.}

By S. BARKer, M.D.

Crown 8vo. price $5 s$.

\section{The Common Sense of the Water Cure.}

A Popular Description of Life and Treatment at a Hydropathic Establishment. By Captain J. H. Lukis, late of the 61st Regiment, and the North Durham Militia.

"We have seldom read a more amusing book than this. Capt. Lukis is a clcver well-bred gentleman, who has found the greatest pleasure of his life in the strict dis cipline of hydropathy, and in this volume he chats pleasantly about his own experiences, and puts in a very popular form the chief arguments in favour of the water cure. There is not a dull page in the book." -Morning Heruld. 
Crown 8vo. cloth, price $2 s .6 d$.

\section{The Gastric Regions, and the Vic- tualling Department.}

By An Old Militia Surgeon. The whole outward and inward man, from the crown of his head to the corns on his little toes, all tell the sad tale of the Gastric Regions' Wrongs.

" This is a most useful, and by no means a dull or heavy book. . . . The Old Militia Surgeon gives some most useful advice, in a pleasant practical manner, respecting different varieties of food and their effeets upon the system."-Observer.

Crown 8vo. price $5 s$.

BRITISH ASSOCIATION, 1865.

\section{Report of the Proceedings at the Birmingham Meeting.}

Carefully collated and revised by the various Speakers.

8vo. cloth, price $10 \mathrm{~s} .6 \mathrm{~d}$.

\section{On the Arcus Senilis, or Fatty Degeneration of the Cornea.}

With numerous Illustrations. By Edwin Canton, F.R.C.S., Surgeon to the Charing Cross Hospital.

"This book is both interesting and curious. . . It is scarcely within our province to pronounee upon its merits iu a professional point of view; but we may observe that it seems to be the production of a gentleman who has given long and eareful study to his subject, aud who, knowing it thoroughly, both through his own independent investigations and the writings of others, is enticled to speak upon it with authority." - Caledoniun Mercury.

$8 v o .$, sewed, price $1 s$.

\section{Bathing: How to do it, When to do it, and Where to do it.}

By Engar Sheppard, M.D., Medical Superintendent of the Male Department, Colney Hatch Asylum. 
Second Edition, Fcap. 8vo. cloth, price 3 .

\section{On Scarlatina and its Treatment.}

By I. Baker Brown, F.R.C.S., \&c.

$8 v o$. cloth, $7 s, 6 d$.

\section{The Human Brain ;}

Its Configuration, Structure, and Physiology; Illustrated by References to the Nervous System in the Lower Orders of Animals. By Samcel Soldy, F.R.S., Senior Surgeon to St. Thomas's Fiospital, Member of the Council, and late Professor of Anatomy and Surgery in the Royal College of Surgeons, \&c.

"We have perused the work with much attention and no inconsiderable degree of gratification."-London and Edingburgh Philological MIagazine.

" Excellent in its conception, perspicuous in its style, and lucid in its descriptions." - Medical Chirurgical Review.

"It affords us great pleasure to be able to recommend it most unreservedly."Edinburgh Medical and Surgical Journal.

"Treated in a manner that reflects the highest credit upon his industry-and talents." -London Medical Gazette.

"Mr. Solly has entitled himself to the gratitude of a numerous class of readers." -British and Foreign Medicul Review.

Royal 8vo. cloth, price $8 s$.

\section{The Ophthalmoscope ;}

Its Varieties and its Uses. Translated from the German of Zander By R. B. Carter, F.R.C.S. Eng. (by Exam.). With Notes and Additions. 68 Woodcuts and 3 beautiful Coloured Chromo-lithograpbs.

"We have thus very cursorily alluded to the chief contents of this volume, which is illustrated by numerous moodcuts and three coloured lithographic plates ; and, in conclusion, we feel warranted in asserting that it is by far the best practical guide to the use of the Ophthalmoscope that exists in our language." -Dublin Quurterly Journal.

Fcap. 8vo. cloth, illustrated, price $2 s .6 d$.

\section{The Foot and its Covering.}

With Dr. Camper's work on "The Best Form of Shoe," translated from the German. By James Dowie.

"A very sensible treatise, by one who takes an artistic and scientific interest in his subject, and who has evidently well studied the mechanical structure and action, as well as the anatomy and physiology, of that wonderful concatenation of bones, sinews, and muscles-the human font." -Builder.

"To all pedestrians it must be an object to have an easy shoe, and in the present day of universal military ardour and hebdomadal marchings out, this little contribution may prove a useful adviser upon the subject."-Lancet. 


\section{The County Families;}

Price 2. 2s. 1,200 Pages, 11,000 Families.

or, Royal Manual of the Titled and Untitled Aristocracy of the Three Kingdoms, is now ready in one splendid volume. It contains a complete Peerage, Baronetage, Knightage, and Dictionary of the Landed Commoners of England, Scotland, Wales, and Ireland, and gives a brief notice of the Descent, Birth, Marriage, Education, and Appointments of each Person, his Heir Apparent or Presumptive, a Record of the Offices which he has held, together with his Town Address and Country Residences. By Edward Walford, M.A., late Scholar of Balliol College, Oxford.

"It possesses advantages which no other work of the kind that we know of has offered hitherto. Containing all that is to be found in others, it furnishes information respecting families of distinction which are not to be found in the latter. It will prove to be invaluable in the library and drawing-room." - spectutor.

" To produce such a work in the perfection which characterizes 'County Families,' must have heen an almost Herculean task. It is sufficient for us to say that accuracy even in the minutest details appears to have been the aim of Mr. Walford, and the errors are so few and slight, that they may readily be passed over." - Weekly Register.

By the same Author, published Annually; elegantly bound, with gill edges, price $5 s$.

\section{Hardwicke's Crown Peerage :}

Containing a Peerage, Baronetage, and Knightage complete in one volume; and giving the Birth, Accession, and Marriage of each Personage, his Heir (Apparent or Presumptive), Family Name, Political Bias, and Patronage; as also a brief Notice of the Offices which he has hitherto held, his Town Address and Country Residences. Also, published Annually,

\section{The Shilling Peerage; \\ The Shilling Baronetage ; \\ The Shilling Knightage ; and \\ The Shilling House of Commons.}

Demy 8vo. cloth, price 6s.

\section{An Index to the Pedigrees contained in the printed Heralds'Visitations,}

\&c. \&c. By George W. Marshall, LL.M., of the Middle Temple, Barrister-at-Law. 
Royal 32 mo. price $1 s$.

\section{How to Address Titled People."}

Companion to the Writing-Desk; or, How to Address, Begin, and End Letters to Titled and Official Personages, together with Tables of Precedence, copious list of Abbreviations, Rules for Punctuation, and other useful information.

"A word, and more than a word, of praise is due to the Companion to the Writing-Desk. Full information on every subject of importance to correspondents is afforded in it. The instructions on official points will not fail to be of importance to many persons unable to obtain the proper information from even much larger works of the same kind." - Court Journal.

"This is one of the most useful little books we have for a long time seen."-Era.

Demy 8vo. cloth, with Illuminated Frontispiece, price $6 s$.

Mr. Planché's Work on Heraldry. With more than 200 Illustrations from the most authentic sources.

\section{Heraldry founded on Facts.}

Or, The Pursuivant of Arms, by J. R. Planché, Rouge Croix. Second edition, with additional Notes and Illustrations.

"The increased interest taken of late years in heraldry is evinced by the number of works which have appeared to elucidate it. Among these the first place must be assigned to Planché's 'Pursuivant of Arms,' a rigorously scientific examination into the origin and early history of coat-armour, in which everything is submitted to the test of a stern criticism. The author is a distinguished member of the English College of Arms, and has performed the difficult task of producing an Essay on heraldry full of learning and research, yet written in a sufficiently lively style to be read with delight by many who are not heraldic enthusiasts." - Edinburgh Review, April, 1865.

Demy 8vo., Illustrated, price $15 s$.

\section{A Corner of Kent.}

Some Account of the parish of Ash-next-Sandwich. By J.R. Planché, Rouge Croix.

Bcautifully printed in colours, price $\mathfrak{E} 1$. 1 s.

\section{Enshrined Hearts.}

Enshrined Hearts of Warriors and Illustrious People. By Emrur Sophia Hartshorne. With Illuminated Initials, and illustrated with numerous Engravings on Wood, Armorial Bearings, \&c. \&c. 


\title{
Elements of Arithmetic.
}

From the French of M. C. Briot. Translated by J. Spear, Esq.

"The little book before us is a translation of a French school arithmetic, and we notice it especially in reference to the metric system, which is clearly explained in its pages, and put forward in the introduction as one of the prominent features of the work." -Morning Star.

Bound in Leather.

\section{Mangnall's Questions, Complete, 1s.}

The Cheap Edition of this valuable School Book is now ready. It has been carefully revised and brought up to the present time. It is well printed and strongly bound.

"Published in a compact form, neatly bound, and being condensed without being abridged, comes before us in a greatly-improved form. Few books contain so much information in so small a space." -Portsmouth Guurdiun.

Folio boards, price $6 s$.

\section{Inventive Drawing:}

A Practical Development of Elementary Design. By Edward BALL.

"We recommend Mr. Ball's book especially to the instructors of the very young, because we helieve that the system upon which it is founded will produce power which in more advanced life will be invaluab.e to the student of free hand drawing and ornamental design."-Midland Conties Herald.

Price 2s. 6d. Illustrated by Diagrams and Samplars.

\section{Method for Teaching Plain Needle- work in Schools.}

\author{
By a Lady.
}

This useful method is based on steps which are gradual, well-defined, and clear to the perception. It is calculated to insure the improvement of each individual child, and, while it offers the necessary instruction to the less talented pupil, it enables the more clever one to attain the highest degree of perfection. 


\section{Hardwicke's Elementary Books. PRICE TWOPENCE EACH.}

UNDER the above title is presented to the Public a complete Library of Elementary Works adapted for the use of the People.

Thousands of people at present skilled as handicraftsmen, and as workers in the various arts and sciences of life, work from day to day, plodding on with some vague notion that they can improve their own particular calling; but it generally ends in nothing, because they are ignorant of the first principles of those laws which regulate the things in which they are engaged. It is a very rare occurrence to meet with workmen who know anything beyond what they picked up in their apprenticeship, or obtained by imitating others more skilled than themselves.

It will be the aim of Hardwicke's ElEMENTARY Books to teach these first principles.

No labour or expense will be spared to make the information of a thoroughly reliable character; and, where advisable, a free use of authentic illustrations will be brought to bear.

"Hardwicke's series of 'Elementary Books of Science' at present includes Optics, Hydraulics, Hydrostatics, Geography, Chemistry, Mechanics, and the parts vary in price from twopence to sixpence. Against the materials, the writing, or the illustrations we nave not a word to say; and in them very much to praise.... Each part is a very admirable epitome of the subject it treats, and there is more reliable information in any one of these little pamphlets of a few pence than there is in many a costly volume. The woodcuts are in outline, or only slightly shaded, and their subjects are exceedingly well selected."-London Review.

\section{Mechanics.}

\section{NOW READY:-}

Fully illustrated by ncarly 100 cuts. Two parts, 2d. each; complete, 4 d. ; bound in cloth, $6 \mathrm{~d}$.

\section{Hydrostatics.}

Fully illustrated. Complete, 2d.; in cloth, $1 \mathrm{~d}$.

\section{Chemistry.}

Three Parts, $2 \mathrm{~d}$. each ; complete, 6d. ; cloth, 8d.

\section{Hydraulics.}

Fully:Illustrated. Complete, 2d.; cloth, 1 d.

\section{Optics.}

Fully Illustrated. Complete, $4 \mathrm{~d}$; cloth, $6 \mathrm{~d}$.

\section{Pneumatics.}

Fully. Illustrated, 2d.

Other Works of a similar character are in preparation, and will shortly be announced. 


\title{
Mackenzie's Educational Books.
}

\author{
ALREADY PUBLISHED.
}

Mackenzie's Tables.

Commercial, Arithmetical, Miscellaneous, and Artificers'. Calculations in Bricklaying, Carpentery, Lathing, Masonry, Paper-hanging, Paving, Planting, Plasterirg, slating, Tiling, Well-sinking, Digging. \&c. \&c. Fractions and Decimals. Forms of Receipts and Bills. Calculations on Man, Steam, Railways, Power, Light, Wind, \&c. Language and Alphabets. Calendar of the Church. Scripture Money. Principal Foreign Moneys and Measures. Geographical and Astronomical Tables, \&c, \&c. Complete, price 2d., Cloth $6 d$.

Murray's English Grammar.

Complete, word for word with the Shilling Editions. Price $2 d$., Cloth $4 d$.

Mavor's Spelling.

With numerous Cuts. Price $4 d$., or 2 parts $2 d$. each.

Walkinghame's Arithmetic.

Same as the Half-crown Edition. Price 4d, or 2 parts $2 d$, each, , Cloth $6 d^{\circ}$

Short-Hand.

With Phrases and Exercises, to gain facility in the use of all the characters, by

which perfection may soon be attained. Complete, price $2 d$.

Phrenology

Explained and Exemplified. Complete, price $2 d$.

Bookkeeping

By Single Entry, with explanations of Subsidiary Books, being \& useful system

for the Wholesale and Retail Shopkeeper. Complete, price $2 d$.

Limp cloth, 1s.; Bound in Leather, with caloured Maps, 1s.6d.; in paper, without Maps, $6 d$.

\section{A Manual of Geography.}

Being a Description of the Natural Features, Climate, and Prodactions of the variuus regions of the Earth. By Francis Morton, C.E.

Crown 8vo., cloth, price $6 s$.

\section{Holiday Papers.}

By Harry Jones, M.A., Incumbent of St. Luke's, Berwick-street, Soho. Thirty-seven papers.

"Full of deep-toned feeling."-Bell's Messenger.

"His a necdotes would have delighted White of Selborne." - London Review.

"Easy and smart, sparkling and forcible, yet perfectly natural and sensible." Patriot. 
Seventh Edition, Crown 8vo.price 6s.

\section{Curiosities of Civilization.}

Being Essays from the Quarterly and Edinburgh Reviews. By Dr. ANDREW WYNTER.

\section{CONTENTS.}

The London Commissariat. Food and its Adulterations. Advertisements.

The Zoological Gardens.

Rats.

Woolwich Arsenal.

Shipwrecks.
Lodging, Food, and Dress of Soldier's.

The Electric Telegraph.

Fires and Fire Insurance.

The Police and the Thieves.

Mortality in Trades and Professions.

Lunatic Asylums.

"We shall look in vain, for example, two centuries back, for any thing like an equivalent to the volume before us. Some of the articies are mainiy derived from observations made in the course of professionai studies; others are at least cognate to the subjects which occupy a physician's hourly thoughts; all are more or less instructive as to certain phases of our civilization, and the strange elements it holds in suspension. Some of the incidents are of unparalleled magnitude, quite as striking as anything contained in the wonder-books of our ancestors." - Times.

Crown 8vo. price 6s., Eighth Edition,

\section{Our Social Bees.}

Pictures of Town and Country, and other Papers. By ANDREw WrNTER, M.D. Containing articles amongst which will be found,-Mock Auctions-Hyde Park-Our Peck of DirtCommercial Grief_-Orchards in Cheapside-Needle-making-Preserved Meats-London Stout-Wenham Lake Ice-Candle Making -Woman's Work-The Turkish Bath-Who is Mr. Reuter?-A Suburban Fair-The Englishman Abroad-A Gossip about the Lakes-Physical Antipathies-Brain Difficulties.

\section{Also, uniform in size and price,}

\section{Our Social Bees. New series.}

Containing, amongst other articles,-Hedging against FateLondon Omnibuses-Water Supply of London-Buried HistoryOur Furniture-Our once Fat Friend-My First Deal in Horseflesh-Horses and Horse Copers-Our Great Iron-worker'sMachine Tool-makers-The School of Cookery-Sweets for the Million-Death in the Match-box-Human Wasters-The City Companies-Photo-Sculpture-"Old Clo" "-Longevity-A Word about Wines.

"These papers are characterized by the same breadth of view, the same felicity of language, the same acuteness of thought, which distinguished the 'Curiosities of Civilization.' So long as Dr. Wynter continues to write papers similar to those in the volume before us, and in 'Curiosities of Civilization,' so long will the republication of those papers be welcomed by the public." - Standard. 
Crown 8vo., cloth, price $6 s$.

\section{Subtle Brains and Lissom Fingers;}

Being some of the Chisel-marks of our Industrial and Scientific Progress, and other Papers. By A. Wrvter, M.D., M.R.C.P. Lond. Containing 39 Articles; amongst which will be found :

Fraudulent Trade Marks

A Day with the Coroner

Undersea Railroad

Vivisection

Restoration of our Soil

Railways the great Civilizers

Physical Education

Clerk of the Weather
Village Hospitals

Air Traction

Illuminations

Boat-building by Machinery

Doctors' Stuff

Sinall-Pox in London

Excursion Trains

Early Warnings, \&c. \&c.

Second Edition. Crown 8vo. cloth, 624pp., price $6 s$.

\section{The Stream of Life on our Globe.}

Its Archives, Traditions, and Laws, as revealed by Modern Discoveries in Geology and Palæontology. A Sketch in Untechnical Language of the Beginning and Growth of Life, and the Physiological Laws which govern its progress and operations. By J. L. Milton, M.R.C.S.

\section{Contents.}

The Beginning of Life

England, long, long ago

'The First Dwellers on Earth

The First Builders

The First Wanderers

The First, Colonists of Sacred

History

The First Language

The First Alphabet

The Battle of Life
Glances at the Laws of Life

Life in the Blood

Life in the Nerves

Life of a Giant

Life of Men of Genius

Influence of Smoking on Life and Race

Life in the Stars and Planets; or, Coloured Stars and their Inhabitants, \&c. \&c.

"A very agreeably-written record of some of the newest and most remarkable discoveries in geology, language, and physiology. The language is always untechnical and picturesque. It has the merit of inspiring interest in subjects often treated in a manner to repel the ordinary reader."-Lancet.

New Edition, folio, fully illustrated, price $12 s$.

\section{Country Cottages.}

A Series of Designs for an Improved Class of Dwellings for Agricultural Labourers. By Joнn Vincent, Architect. With numerous Plans, Elevations, \&c. 
In two splendid Library volumes, price $£ 1.12 s . ;$

India proofs, $£ 3.3 s$.

\section{Researches into the History of the British Dog.}

From Ancient Laws, Charters, and Historical Records. With Original Anecdotes and Illustrations of the Nature and Attributes of the Dog, from the Poets and Prose Writers of Ancient, Mediæval, and Modern Times. By George R. Jesse. With 33 engravings, designed and etched by the Author.

Third Edition, price 1s.6d., with Illustrations.

\section{A Treatise on Smoky Chimneys,}

Their Cure and Prevention. By Frederick Edwards, Jun.

"We cordially recommend this successful attempt to teach a few plain, but too often neglected, rules. The great charm of the treatise is its conciseness and practical usefulness. Attention to the facts Mr. Edwards has indicated in it will save landlurds and householders a deal of trouble, expense, and anxiety. The work will serve as an excellent companion to the book, by the same author, on 'Our Domestic Fireplaces,' which we see has also reached a second edition."-Building News:

Second Edition, revised, with Sixteen Plates, price 6s.

\section{Our Domestic Fireplaces.}

A Treatise on the Economical Use of Fuel and the Prevention of Smoke; with Observations on the Patent Laws. By Frederick Enwards, Jun.

"On the strength of the aphorism of every man to his trade, we may inquire who should be a more competent persen to give us information about fireplaces than a well-informed practical man who has manufactured thousands of them, and made an examination of their respective merits a life-long study? Thus Mr. Edwards has not confined himself to a scale of praises upon the particular grates manufactured by his own firm, but has fairly weighed the merits of many that are patented by their inventors, and are therefore inaccesoible to him as a source of profit." - Builder.

Published Annually, price $1 s$.

\section{The Royal

Showing, in Alphabetical Order, the Name, Date of Foundation, Address, Object, Annual Income, Number of People benefited, Mode of Application to and Chief Officers of every Institution in London. By Herbert Fry. 
Royal 32 mo. cloth, price 18.

\section{Hardwicke's Shilling Handy-Book of London.}

An Easy and Comprehensive Guide to Everything worth Seeing and Hearing.

Contents :-Bazaars. - Ball-rooms. - Cathedrals. - Dining-rooms. - Exhibitions. -Mansions of Nobility._Markets.-Money-order Offices. - Monuments and Statues. - Museums. - Music-halls and Concertrooms.-Out-door Amusements. - Omnibuses. - Palaces. - Parks. Passport Offices.-Picture Galleries' Regulations.-Popular Entertainments.-Police-courts. - Prisons.—Railway Stations. - Steamboats.Theatres.-Telegraph Offices, \&c.

\section{Demy 8vo., 860 pages, price $21 s$.}

\section{The Cattle Plague.}

With Official Reports of the International Veterinary Congresses, held in Hamburg, 1863, and in Vienna, 1865. By John GaMgeE, Principal of Albert Veterinary College. Fcap. 8vo. cloth, price 3 s. $6 d$.

\section{Horse Warranty.}

A Plain and Comprehensive Guide to the various Points to be noted, showing which are Essential and which are Unimportant. With Forms of Warranty. By Peter Howden, V.S.

With Illustrations. Fcap. Svo. cloth, price $28.6 d$.

\section{Graceful Riding.}

A Pocket Manual for Equestrians. By S. C. WArTe.

"In the school, on the road, on the course, or across country, this little book will be invaluable; and we heartily recommend it."-Morning Post.

Fcap. 8vo. cloth, price 6s.

\section{Waste Products and Undeveloped Substances;}

Or, Hints for Enterprise in Neglected Fields. By P. L. Srmmonds, Author of "Products of the Vegetable Kingdom," \&c.

"As mere reading, the Volume is interesting and instructive; but we must go further, anil say there are fortunes to be got out of it by those who rightly work some of its suggestions." - Builder. 
With coloured Frontispiece. 16mo. cloth, gilt edges, price 2s. $6 d$. Whist.

The Laws and Practice of Whist. By Cercers. As played at the London Clubs.

"It is just the book that was required. The intrinsic worth of the book is to be found in the downright sensible practical advice contained throughout its pages, and to the lover of whist we strongly recommend the volume." - Field.

16rno. cloth, price $2 s .6 \mathrm{~d}$.

\section{One Hundred Double Acrostics.}

A New Year's Gift. Edited by "Myself."

Crown Svo. cloth, price 6s.

\section{Alexander von Humboldt;}

or, What may be accomplished in a Lifetime. By F. A. SCHWARZENBERG.

Fcap. 8vo. price $3 s .6 d$.

\section{Autobiography of a Working-man.}

By Alexander Somerville, "One who has whistled at the plough."

Crown 8vo. cloth, with Illustrations by George Cruikshank, price $2 s .6 d$. ; the Illustrations on India paper, price $5 s$.

\section{Peter Schlemihl.}

From the German of Adalbert Von Chamisso. Translated by Sir JohN Bowring, LL.D., \&c. Fcup. 8vo. cloth, price 5s.

\section{Wines and other \\ Fermented}

\section{Liquors.}

From the Earliest Ages to the Present Time. Dedicated to all Consumers in the United Kingdom. By James Richmond Sheen. F cap. 8vo. cloth, price 6s.

\section{Shooting Simplified.}

A Concise Treatise on Guns and Shooting. Second Edition, ReWritten and Enlarged, with a Special Chapter on Breech-Loaders. By James Dalziell Dougall. 


\section{Crown 8vo. cloth, price $6 s$.}

\section{Essays and Reviews.}

Their Origin, History, General Character and Significance. Persecution, Prosecution, Judgment of the Arches Court, Review of Judgment. By the Rev. Robert Bruce Kennard, M.A., Rector of Marnhull, Dorset.

Crown $8 v a$. cloth, price $3 s .6 d$. Dedicated by permission to C. Dickens, Esq.

\section{A Tramp's Wallet.}

Stored by an English Goldsmith during lis Wanderings in Germany and France. By William Duthie.

Monthly, 4d.; Quarterly, 1s.; Annual Volume, in cloth, 5s.

\section{Hardwicke's Science-Gossip :}

A Monthly Medium of Interchange and Correspondence for Students and Lovers of Nature.

Hardwicke's Science-Gossip consists of :-

1. Short Articles of an interesting and light character,

On Animals, Birds, Reptiles, \&c., their Habits, Haunts, Pecaliarities, and Migrations; and on Stuffing and Preserving.

On the Finding, Collecting, and Preserving of the Microscopic Plants and Animals.

On Fish, Fish Culture, and Fishing.

On Plants, their Habitats, time of Flowering, Soils where likely to be found; Peculiarities of Structure, \&c.

On Geology ; Excursions in interesting districts, and any subject relating to the Wonders, Peculiarities, or History of the World's Crust.

On the Habits, Mode of Capture, and Preservation of all sorts of Insects.

On the Cultivation of Ferns, Mosses, \&c.

On the various Plants and Animals capable of being kept and bred in Aquaria and Closed Cases.

On the Uses and Application of the Microscope, and on Mounting Objects. Discussions on any New Invention, or Improvement upon Old Instruments.

In fact, in any subject which those who have a sincere love of God's works delight to talk about, when they meet for a friendly gossip.

2. Hints and Suggestions, too small for Articles, but such as may prove useful either in Hunting, Preserving, Observing, or Understanding the various objects of Study.

3. Notes and Queries.

4. Interesting Selections from Books.

5. Notices to Correspondents.

Hardwicke's ScIence-Gossip is published on the First of every Month, price Fourpence. Communications and Suggestions are invited. All letters to be addressed to the Editor, 192, Piccadilly. 


\section{Quarterly, Half-a.Croun; Annual Subscription, Ten Slillings,}

\section{THE \\ POPULAR SCIENCE REVIEW,}

A

\section{QUARTERLY SUMMARY OF SCIENTIFIC PROGRESS,}

\section{AND MISCELLANY OF ENTERTAINING AND INSTRUCTIVE ARTICLES ON SCIENTIFIC SUBJECTS.}

\section{EDITED ti HENRY LAWSON, M.D.,}

Author of "A Popular Manual of Physiology." Co-Lecturer on Physiology and Histology, St. Mary's Medical School.

\section{VOLUIME IV.}

Five Quarterly Purts, $696 \mathrm{pp}$. of Letter-press, numerous Woodcuts, and 24 whole page Plates, by first-rate Artists, price 14s. 6d., contuining the following interesting Articles:-

Estraordinary Ships. By S. J. Mackic, F.G.S. With 18 Woodcuts and Plates of "Cigar-ship" and "Cornecturship."

Good Food. By Dr. Lankester, F.R.S. On the Origin of our Local Floras. By Harland Coultas. With Map of Distribution of Flowering Plants.

Metamorphism of Rocks, \&e. By Professor Ansted.

The Metric System. By James Spear, Esq. With Plate of Weights and Measures.

Recent Investigations into the Natural History of the Red Coral. By the Editor. With Coloured Plate.

What is a Stimulant? By Dr. Anstie.

Source of Heat in the Sun. By Robert Hunt, F.R.S. With Woodcuts and 2 Coloured Plates.

On New Food for Infants. By Baron Liebig. (This Article was thc means of introducing "Liebig's Food for Infants " into this country.)

Yegetables, Fruit, and Water, as Sources of Intestinal Worms. By Spencer Cobbold, M.D., F.R.S., F.L.S.

The Anatomy and Physiology of Foraminifera. By Professor Williamson, F.R.S. With Tinted Plate.

Waves of Heat and Waves of Death. By B. W. Richardson, M.A., M.D.
Origin of Kitchen-Garden Plants. By Harland Coultas. W'ith Plate of Wild Parsnip, Carrot, Radish, Turnip. \&ec.

Geology of Mineral Springs. By Francis Bond, M.D., B.A., F.C.S. Wi'h Plate. Train Signalling in 'T'ncory and Practice. By Charles V. Walker, F.R.S., F.R.A.S. With Woodcuts and Plate, showing the arrangement of Signal-room.

Extract of Meat. By Charles Boner.

On Sponges, By Robert Patterson, F.R.S. W'ith Tinted Plate of Structurc.

The Physical Phenomena of other Worlds. By Robert Hunt, F.R.S. With Coloured Plate of Spectra.

Migrations of European Birds. By A. Leith Adams, M.A., M.B., F.G.S., F.L.S.

On the Difficulties in Idcntifying many of the Lower Kinds of Algæ. By J. Braxton Hicks, M.D., F.R.S., F.L.S. With Coloured Plate.

On the Oldest linown Fussil-Eozoon Cunadense-its Place, Structure, and Significance. By Professor 'T. Rupert Jones, F.G.S. Wilh Coloured Plate of 10 Sections.

Balloon Ascents and their Scientific Importance. By James Glaisher, F.R.S. With 'I'inted Plate, showing the Arrangement of Instruments in Car of Balloon. 
On the Highest Magnifying Powers and their Uses. By Lionel Beale, MI.B., F.R.S.

On Darwin's Observations on the Pbysiology of Fertilization. By M. C. Cooke. With Plate of Sections of Plants.

What is a Tonic? By Edward Divers, M.D., F.C.S.

The Eruption of Etna. By S.J. Mackie, F.G.S. With IVoodcuts and Plate, showing Etna and adjacent country.

Inside the Eye. By Ernest Hart, Esq. With Woodcuts.

On the Means of Communicating between Guards and Passengers. By ' $\mathrm{S}$. Symes Prideaux, Esq.

Is the Whitebait a Distinct Species? By the Fditor. With Plate of Whitebait and Shad, and of Whitebait-fishing.

Atlantic Telegraphy. By Robert Hunt, F.R.S. With 2 Plates, showing Map of Cahle from Valentia to Trinity Bay, with Sections of Bed of Atlantic; Section and Side View of Cable, 1865 and 1858. Cab'e from Dover to Ostend. Spezzia to Corsica, Corfu to Malta and Sardinia, Sardinia to Bona, \&e.
On Pure Water. By Dr. Lankester, F.R.S.

Nature and Diagnostic Value of Raphides and other Hlant Crystals. By George Gulliver, F.R.C.S., F.R.S.

On Lake Basins. By Professor Ansted, M.A., F.R.S. With Plate of English, Scotch, Irish, European, and American Lakes.

Epidemics, Past and Present : their Origin and Distribution.

On the Microscopic Anatomy of an Insect Lurva. By E. Ray Lankester: With Plate of Corethra Plumicornis.

The Moon. By James Breen, F.R.A.S. With View of the Moon, from a Photograph.

Photography and some of its Applications. By ihe Editor.

Reviews of Books.

Careful Summary of Progress in Astronomy, Botany and Vegetable Pnysio. $\operatorname{logy}$, Chemistry, Geology and Palzeontology, Mechanics, Medical Science, Metallurgy and Mining, Meteorology, Microscopy, Mineralogy, Photography, Physics, Zoology, and Comparative Anatomy.

\section{VOTUME III.}

(560 pages.of Letter-press, 21 pages of coloured and plain. Illustrations), price; in cloth, 12s., contains-

Photographic Printing; with Page of the "Times," quite legibly printed, $4 \frac{1}{2}$ by 5 inches.

The Alps Railway Tunnel. (Illustrated.)

Metropolitan Main Drainage Works. (Illustrated.)

Printing Telegraphs; with Fac.similes and Explanations of Wheatstone's, $\mathrm{Ca}$ selli's, and bonclli's Systems.

The Pneumatic Lespatch. With Explanatory Illustrations.

Microscopic Fungi, Smuts and Bunt, Mildew and brand, Mouids, Rusts, \&c. By M. C. Cooke. 7 coloured Plates; 170 figures.

Fresh Air. By Dr. Lankester, F.R.S.

Bodily Work and Food. By Professur Bond.

\section{Oysters.}

Herrings and Herring Fisheries.

Diseased Meat. By Professor Gamgee. (lilustrated.)

Fishes of the Old Red Sandstone. E. Ray Lankester. (Illustrated.)
On Proper Clothing. By Dr. Lankester. Earthquakes. By the Rev. W. S. Symonds.

Prehistoric Dwellings. With Illustrations of Hut Circles. By G. E. Roberts.

Thermometry. By G. F. Chambers.

On Manures. By Baron Liebig.

Greek Fire, Ancient and Modern. By Dr. Richardson.

Aniline Dyes. With Illustrations on Silk Fabric.

Absorption and Radiation of Heat. By Professor Debus. (Illustrated.)

Botanical Exercises. By Rev. G. Henslow.

Reviews of Books.

With careful Summary of Agriculture, Astronomy, Botally, Chemistry, Geology and Palæontology, Medical Science, Metallurgy and Mining. Mineralogy, Meteorology, Microscopy, Photography, Physics, Zoology, and Comparative Anatomy. 


\section{THE POPULAR SCIENCE REVIEW-continued.}

\section{VOLUME II.}

(596 pages of Letier-press, 21 page Illustrations), price, in cloth, 12s., contains-

The British Oak, By Professor Buckman. (Illustrated.)

Mistletoe and Parasitic Plants. By Mrs. Lankester. (Illustrated.)

British Fungi. By Miss Plues. (Illus. trated.)

History of a Beech Tree. By Harland Coultas. (Illustrated.)

British Jungemaneæ. (Illustrated.)

Small Periwinkle. (Illustrated.)

Anresthetics. By Dr. Phipson.

Electro-Plating Process. By G. Gore. (Illustrated.)

Colour Blindness. By J. Hogg. (Illus. trated.)

Minerals, Chemicals, Philosophical Instruments, and Implements of War in the Great Exhibition of 1862 .

Red Worm of our Rivers. By E. R. Lankester. (Illustrated.)
The Vinegar Eel. By Jabez Hogg. F.L.S. Our Fresh-water Polyzoa. By the Rev. W. Houghton, F.R.S.

The African Lion. By Jules Gerard.

Fossil Birds. By S. J. Mackie, F.G.S. (Illustrated.)

Wheel Animalcules. By P. H. Gosse. (Illustrated.)

The Eye of the Ox. By Isaac Ash. (Coloured Illustration.)

Human Skin. (Illustrated.)

Mars. (Coloured Illustration.)

The Telescope. By James Breen.

Reviews of Books.

With careful Summary of Astronomy, Botany and Vegetable Physiology, Chemistry, Geology, Medical Sciences, Metallurgy, Nineralogy and Mining, Mechanics, Photography, Physics, Zoology, and Comparative Anatomy.

\section{VOLUMIE I.}

(548 pages of Letter-press, 27 page Illustrations), price, in cloth, 12s., contains-

Artificial Light. By Professor Ansted. The Reflex Theory. By G. H. Lewes.

Solar Chemistry. By R. Hunt, F.R.S. (Coloured Illustration.)

Light and Colour. By R. Hunt, F.R.S. (Coloured Illustration.)

Physics of a Sunbeam. By R. Hurt, F.R.S. (Coloured Illustration.)

Optical Phenomena of the Atmosphere. By G. F. Chambers. (Coloured Illustration.)

The Crown Animalcule. By P. H. Gosse, F.R.S. (Illustrated.)

The Flower Animalcule. By P. H. Gosse, F.R.S. (Illustrated.)

On Corn and On Grass. By Professor Buckman, F.L.S. (Illustrated.)

The Daisy and the White Clover, as type Plants. By Mrs. Lankester. (Illustrated.)

On Cotton. By Jr. Lankester. (Illustrated.)

The Truffle. By Jabez Hogg, F.L.S. (Illustrated.)

Caverns and their Contents. By Professor Ansted.

The Breath of Lifc. By IV. Crookes, F.R.S.
Iron and Steel. By R. Hunt, F.R.S. Artificial Precious Stones. By W. G. Howgrave.

The Great Comet of 1861. By James Breen.

Primitive Astronomy. By J. Samuelson. (Coloured Illustration.)

Equatorial Africa. By J. Samuelson. (With coloured Map.)

The Lowest Forms of Life. By J. Samuelson. (Illustrated.)

Phosphorescence of the Sea. By A. de Quatrefages. (Illustrated.)

Science applied to Electro-plating. By G. Gore.

The Grcat Exhibition of 1862. (Illustrated.)

Suspension and Tubular Bridges. (Illustrated.)

Reviews of Books of the Year.

General Summary of Progress in Astronomy, Botany and Vegetable Physiology, Chemistry, Geology, Medical Sciences, Metallurgy, Mincralogy and Mining, Mechanics, Photography, Physics, Zoology, and Comparative Anatomy.

Quarterly, 2s. 6d.; Annual Subscription, 10s. 





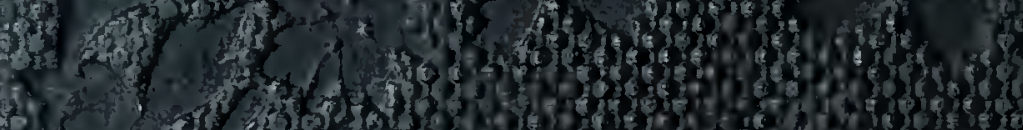

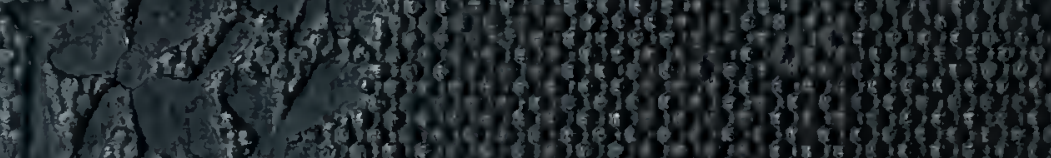

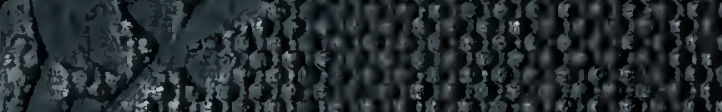

(1)

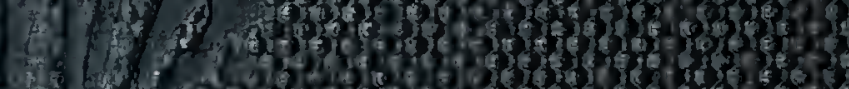

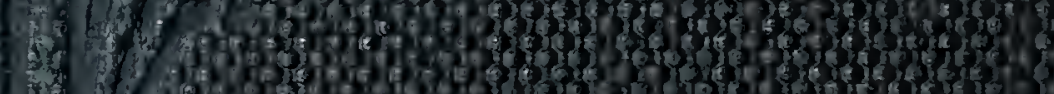

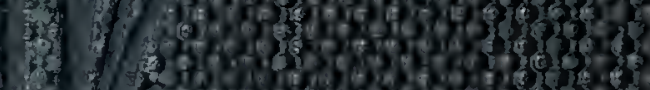

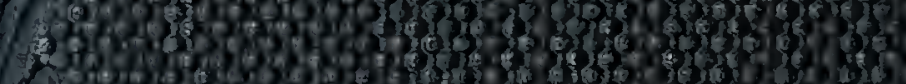

1303 (a)

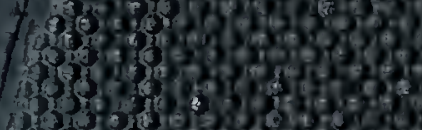

gojof

7930 d

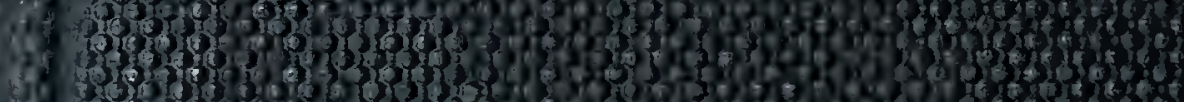

38 s.

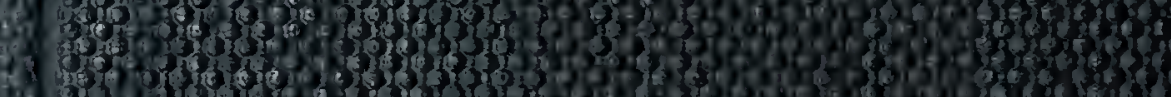

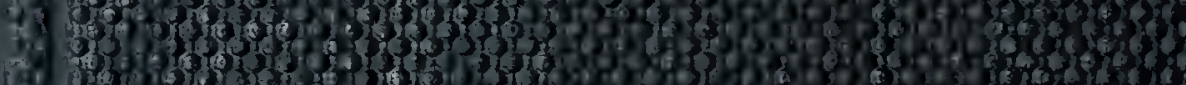

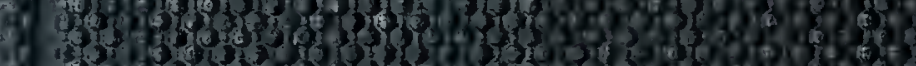

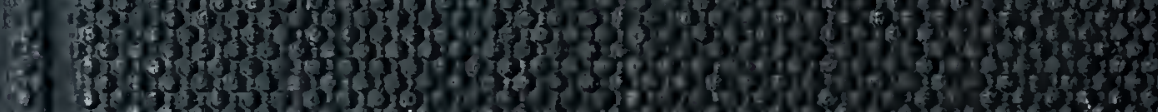

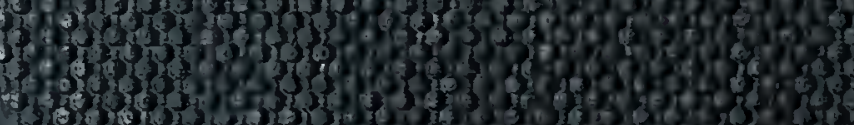

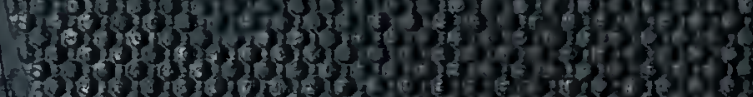

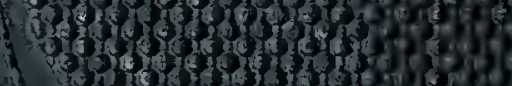

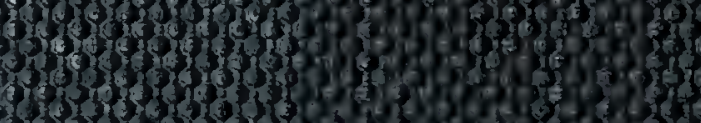

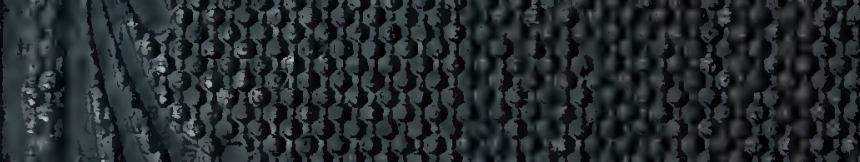

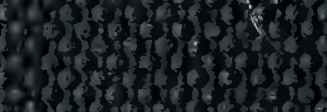

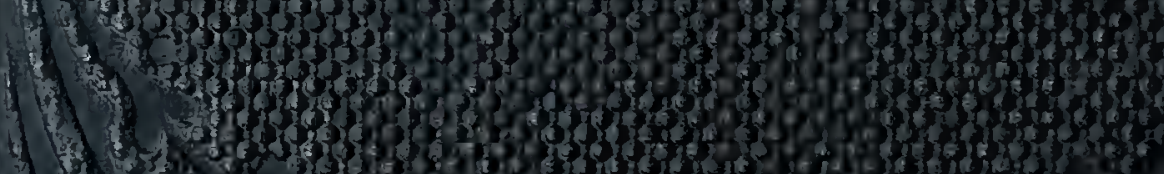

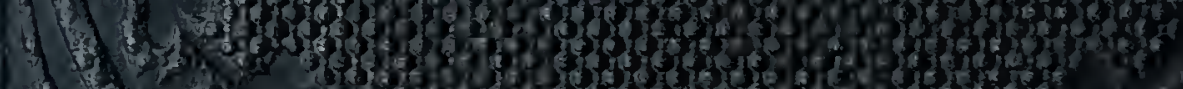

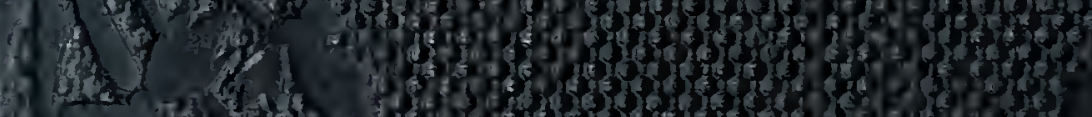

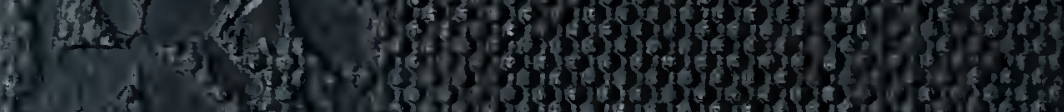

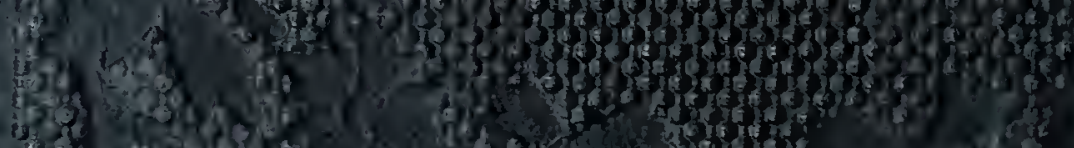

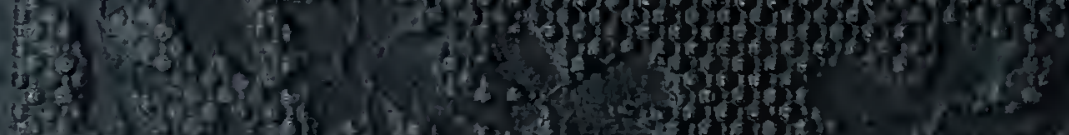

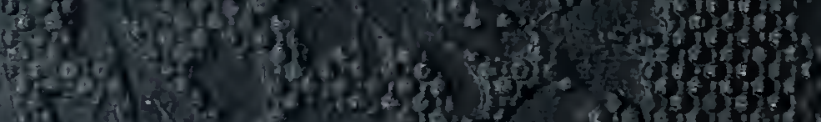

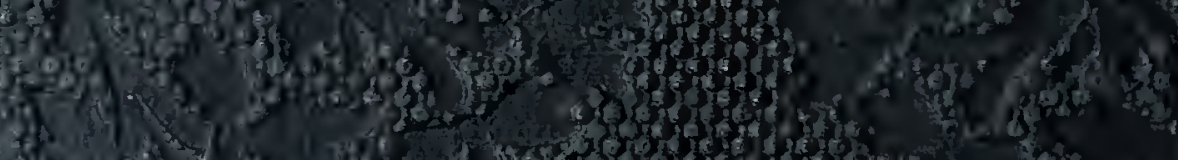

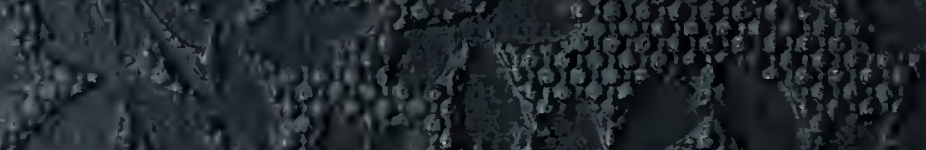

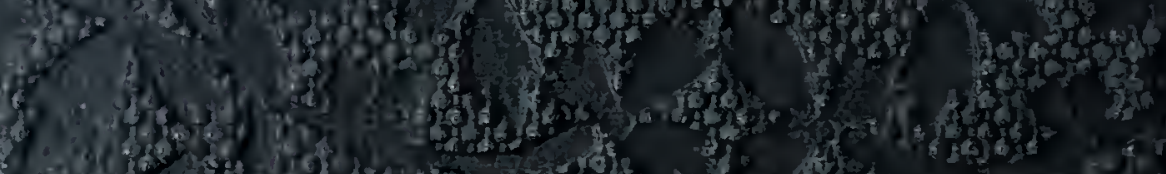

(3)

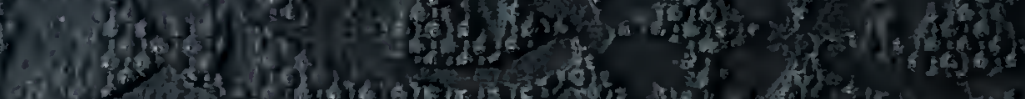

